\title{
‡USGS
}

science for a changing world

Prepared in cooperation with the City of Palo Alto, California

\section{Near-Field Receiving-Water Monitoring of Trace Metals and a Benthic Community Near the Palo Alto Regional Water Quality Control Plant in South San Francisco Bay, California-2017}

By Daniel J. Cain, Janet K. Thompson, Francis Parchaso, Sarah Pearson, Robin Stewart, Mathew Turner, David Barasch, Ané Slabic, and Samuel N. Luoma

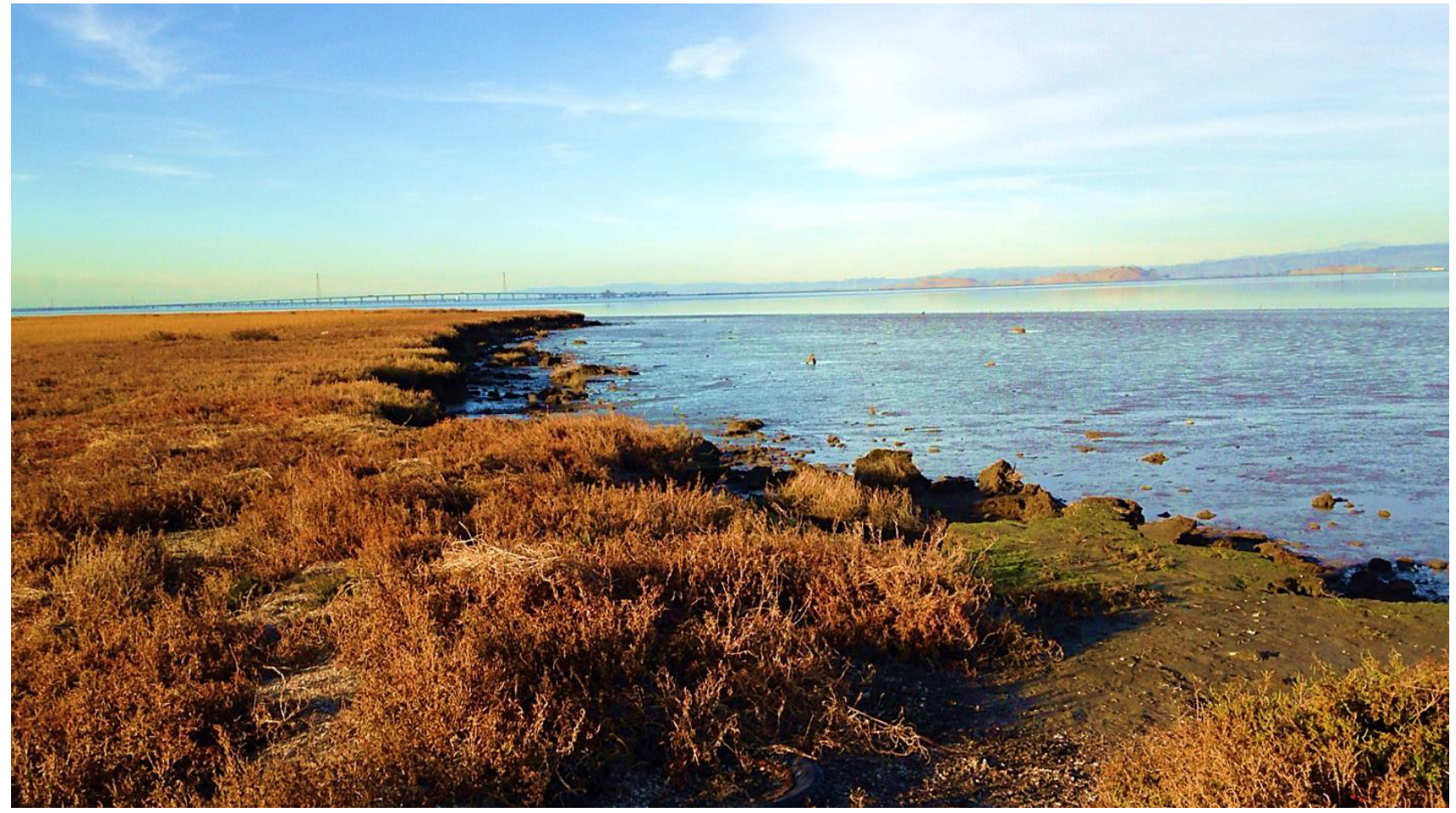

Open-File Report 2018-1107

U.S. Department of the Interior

U.S. Geological Survey 


\section{U.S. Department of the Interior \\ RYAN K. ZINKE, Secretary}

\section{U.S. Geological Survey James F. Reilly II, Director}

U.S. Geological Survey, Reston, Virginia: 2018

For more information on the USGS—-the Federal source for science about the Earth, its natural and living resources, natural hazards, and the environment-visit https://www.usgs.gov/ or call 1-888-ASK-USGS (1-888-275-8747).

For an overview of USGS information products, including maps, imagery, and publications, visit https://www.usgs.gov/pubprod/.

Any use of trade, firm, or product names is for descriptive purposes only and does not imply endorsement by the U.S. Government.

Although this information product, for the most part, is in the public domain, it also may contain copyrighted materials as noted in the text. Permission to reproduce copyrighted items must be secured from the copyright owner.

Suggested citation:

Cain, D.J., Thompson, J.K., Parchaso, F., Pearson, S., Stewart, R., Turner, M., Barasch, D., Slabic, A., and Luoma, S.N., 2018, Near-field receiving-water monitoring of trace metals and a benthic community near the Palo Alto Regional Water Quality Control Plant in south San Francisco Bay, California-2017: U.S. Geological Survey Open-File Report 2018-1107, 71 p., https://doi.org/10.3133/ofr20181107.

Cover. Mudflat at Sand Point, Baylands Nature Preserve, Palo Alto, Calif. Photograph by Daniel Cain, U.S. Geological Survey, 2017. 


\section{Contents}

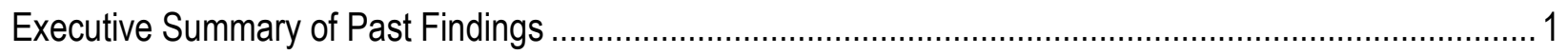

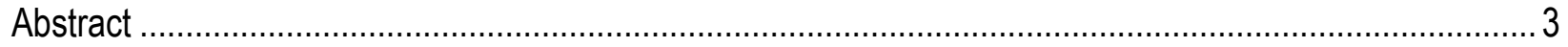

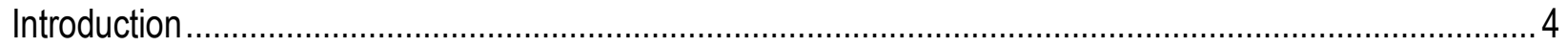

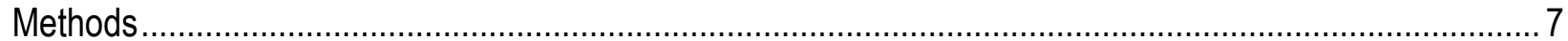

Sampling Frequency and Duration ..............................................................................................

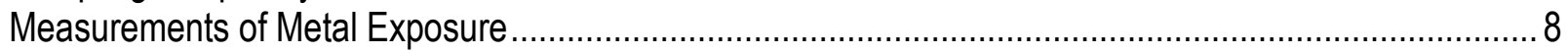

Sediment

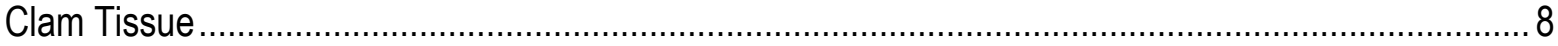

Sample Preparation for Metal Analysis, Excluding Mercury and Selenium ......................................... 8

Analytical, Excluding Mercury and Selenium............................................................................... 9

Sample Preparation and Analysis for Mercury and Selenium ....................................................... 9

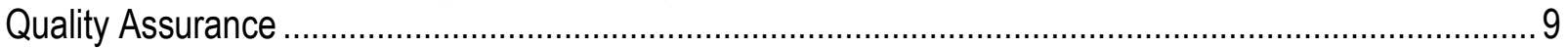

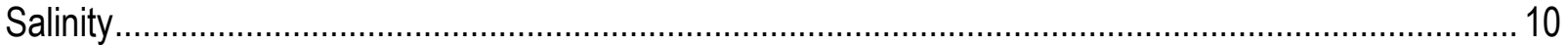

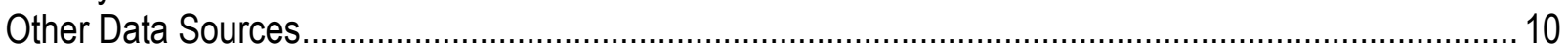

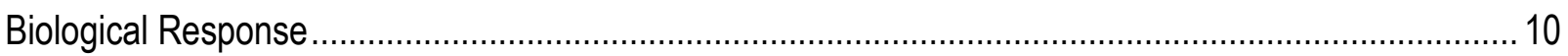

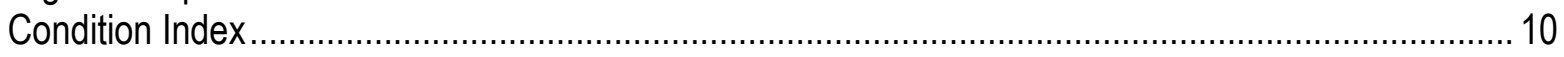

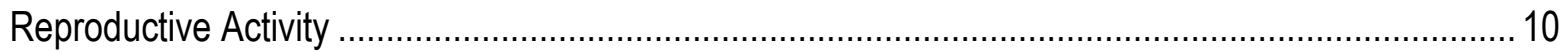

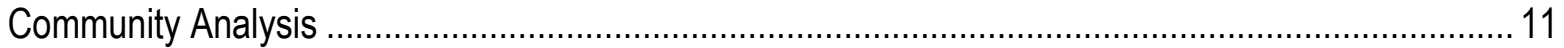

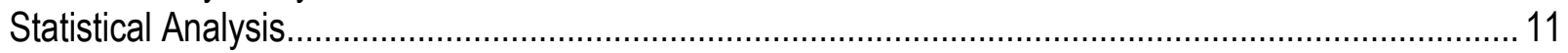

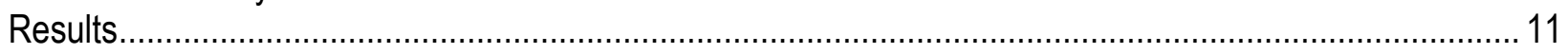

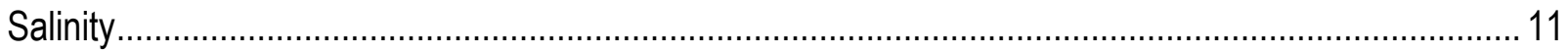

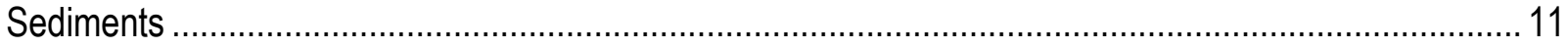

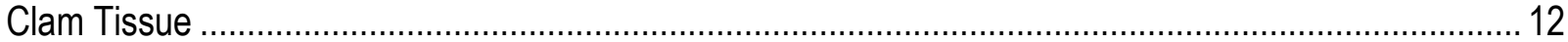

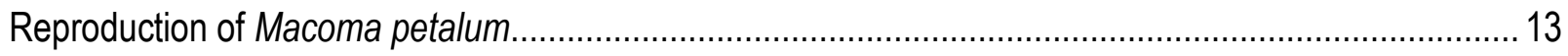

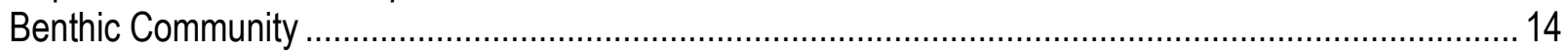

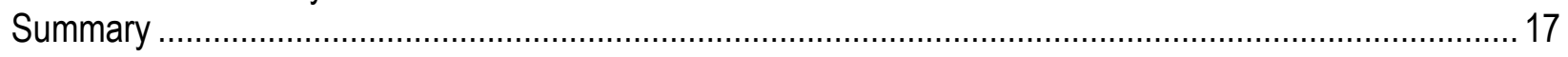

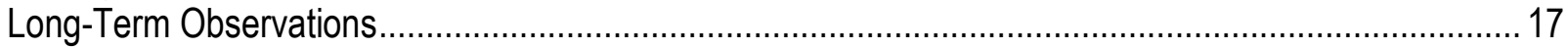

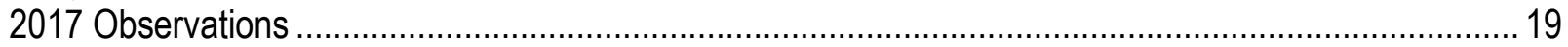

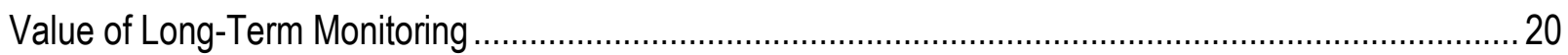

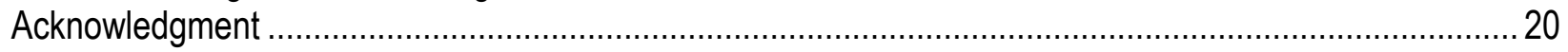

References Cited .................................................................................................................. 20

Appendix 1. Certified concentrations and the percent recoveries of inorganic elements in National Institute of Science and Technology Standard Reference Material 2709a (San Joaquin Soil) and 2711a (Montana Soil) prepared in 2017.

Appendix 2. Certified concentrations and the percent recoveries of inorganic elements in National Institute of Science and Technology Standard Reference Material 2976 (Mussel Tissue) and 1566b (Oyster Tissue) prepared in 2017.

Appendix 3. Mercury and selenium concentrations determined in sample splits of surface sediments and Macoma petalum collected at Palo Alto, Calif., 2017.

Appendix 4. The percent recovery of mercury and selenium in standard reference materials.....................64

Appendix 5. Method detection limits and reporting levels for Inductively Coupled Plasma Optical Emission Spectrophotometry methods.

Appendix 6. Correlation matrix of percent of fine-grained particles and chemical properties of surficial sediment based on monthly means of all samples collected at Palo Alto, Calif., during the period 1994-2017 
Appendix 7. Statistical summary of silver and copper concentrations in sediment and the clam Macoma

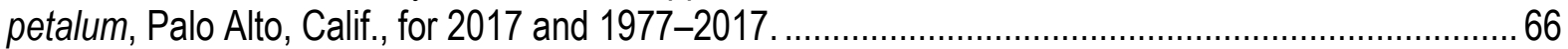

Appendix 8. Reproduction data for Macoma petalum, Palo Alto, Calif., 2013-2017.................................. 66

Appendix 9. Complete list of benthic species found at Palo Alto in the year 2017..................................68

Appendix 10. Benthic species name changes as of 2017............................................................ 71

\section{Figures}

1. Location of the Palo Alto sampling site in south San Francisco Bay, Calif. ..................................2 25

2. Precipitation recorded at San Francisco WB AP in San Mateo County, Calif................................26

3. Surface-water salinity at the Palo Alto site, Calif., 1994-2017 ................................................... 27

4. Aluminum, iron, and silt/clay in sediments, Palo Alto, Calif., 1994-2017 ..................................... 28

5. Chromium and nickel in sediments, Palo Alto, Calif., 1994-2017 ............................................... 29

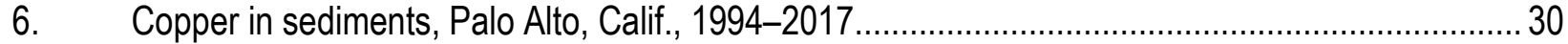

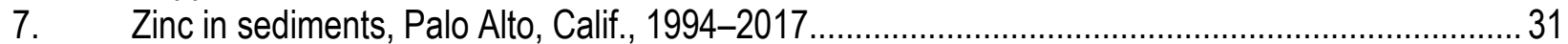

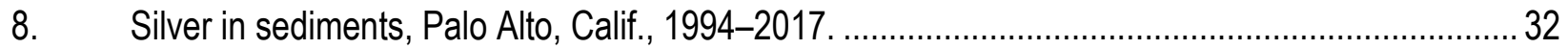

9. Mercury and selenium in sediments, Palo Alto, Calif., 1994-2017 ........................................... 33

10. Condition index of the clam Macoma petalum, Palo Alto, Calif., 1988-2017............................... 34

11. Copper concentrations in the clam Macoma petalum, Palo Alto, Calif., 1977-2017........................35

12. Silver concentrations in the clam Macoma petalum, Palo Alto, Calif., 1997-2017 ......................... 36

13. Chromium and nickel concentrations in the clam Macoma petalum, Palo Alto, Calif., 1994-2017. 37

14. Zinc concentrations in the clam Macoma petalum, Palo Alto, Calif., 1994-2017........................... 38

15. Mercury concentrations in the clam Macoma petalum, Palo Alto, Calif., 1994-2017 ...................... 39

16. Selenium concentrations in the clam Macoma petalum, Palo Alto, Calif., 1994-2017 ..................... 40

17. Reproductive activity of the clam Macoma petalum, Palo Alto, Calif., 1974-2017 ......................... 41

18. Reproductive activity of the clam Macoma petalum, Palo Alto, Calif., 2013-2017......................... 41

19. Total number of species present at the Palo Alto site, Calif., 1974-2017 …….......................... 42

20. Total average number of individuals present at the Palo Alto site, Calif., 1974-2017 .................... 43

21. Monthly average abundance of Macoma petalum, Palo Alto, Calif., 1974-2017 ............................4 44

22. Monthly average abundance of Mya arenaria, Palo Alto, Calif., 1974-2017 .................................. 45

23. Monthly average abundance of Gemma gemma, Palo Alto, Calif., 1974-2017 ............................. 46

24. Monthly average abundance of Ampelisca abdita, Palo Alto, Calif., 1974-2017 ……..................... 47

25. Monthly average abundance of Streblospio benedicti, Palo Alto, Calif., 1974-2017 .......................48

26. Monthly average abundance of Grandiderella japonica, Palo Alto, Calif., 1974-2017................... 49

27. Monthly average abundance of Atilla succinea, Palo Alto, Calif., 1974-2017 ................................50

28. Monthly average abundance of Heteromastus filiformis, Palo Alto, Calif., 1974-2017 ...................51

29. Monthly average abundance of Nippoleucon hinumensis, Palo Alto, Calif., 1974-2017................ 52

30. Reproductive mode annual abundance with silver concentrations in the clam Macoma petalum and in sediment, Palo Alto, Calif., 1974-2017 ...................................................................53

31. Reproductive mode annual abundance with copper concentrations in the clam Macoma petalum and in sediment, Palo Alto, Calif., 1974-2017 ..................................................................... 54

32. Feeding mode annual abundance with silver concentrations in the clam Macoma petalum and in

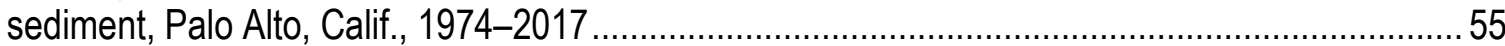

33. Feeding mode annual abundance with copper concentrations in the clam Macoma petalum and in sediment, Palo Alto, Calif., 1974-2017 56

34. Species rank-abundance for the benthic community, Palo Alto, Calif., for 2016 and 2017............ 57 
35. Species rank-abundance identified by feeding mode, Palo Alto, Calif., for 1977, 1989, 2002, and

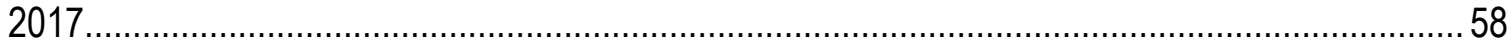

36. Species rank-abundance data identified by reproductive mode, Palo Alto, Calif., for 1977, 1989, 2002 , and 2017.

\section{Tables}

1. Concentrations of fine particles in surface sediments and major and minor inorganic elements for samples collected from Palo Alto, Calif., 2017

2. Concentrations of trace metals and the condition index of the clam Macoma petalum, Palo Alto, Calif., 2017. 


\section{Conversion Factors}

U.S. customary units to International System of Units

\begin{tabular}{|c|c|c|}
\hline Multiply & By & To obtain \\
\hline \multicolumn{3}{|c|}{ Length } \\
\hline inch (in.) & 2.54 & centimeter $(\mathrm{cm})$ \\
\hline inch (in.) & 25.4 & millimeter (mm) \\
\hline foot (ft) & 0.3048 & meter $(\mathrm{m})$ \\
\hline mile (mi) & 1.609 & kilometer $(\mathrm{km})$ \\
\hline \multicolumn{3}{|c|}{ Volume } \\
\hline gallon (gal) & 3.785 & liter $(\mathrm{L})$ \\
\hline \multicolumn{3}{|c|}{ Mass } \\
\hline ounce, avoirdupois (oz) & 28.35 & $\operatorname{gram}(\mathrm{g})$ \\
\hline
\end{tabular}

Temperature in degrees Celsius $\left({ }^{\circ} \mathrm{C}\right)$ may be converted to degrees Fahrenheit $\left({ }^{\circ} \mathrm{F}\right)$ as ${ }^{\circ} \mathrm{F}=\left(1.8 \times{ }^{\circ} \mathrm{C}\right)+32$.

Temperature in degrees Fahrenheit $\left({ }^{\circ} \mathrm{F}\right)$ may be converted to degrees Celsius $\left({ }^{\circ} \mathrm{C}\right)$ as ${ }^{\circ} \mathrm{C}=\left({ }^{\circ} \mathrm{F}-32\right) / 1.8$.

\section{Supplemental Information}

Specific conductance is given in microsiemens per centimeter at 25 degrees Celsius $\left(\mu \mathrm{S} / \mathrm{cm}\right.$ at $\left.25^{\circ} \mathrm{C}\right)$.

Concentrations of chemical constituents in water are given in either milligrams per liter $(\mathrm{mg} / \mathrm{L})$ or micrograms per liter $(\mu \mathrm{g} / \mathrm{L})$.

Activities for radioactive constituents in water are given in picocuries per liter ( $\mathrm{pCi} / \mathrm{L})$.

Results for measurements of stable isotopes of an element (with symbol E) in water, solids, and dissolved constituents commonly are expressed as the relative difference in the ratio of the number of the less abundant isotope ('E) to the number of the more abundant isotope of a sample with respect to a measurement standard.

Note to USGS users: Use of hectare (ha) as an alternative name for square hectometer $\left(\mathrm{hm}^{2}\right)$ is restricted to the measurement of small land or water areas. Use of liter $(\mathrm{L})$ as a special name for cubic decimeter $\left(\mathrm{dm}^{3}\right)$ is restricted to the measurement of liquids and gases. No prefix other than milli should be used with liter.

\section{Abbreviations}

$\begin{array}{ll}\mathrm{mL} & \text { milliliter } \\ \mu \prime \Omega-c m & \text { microohm per cm } \\ \mu \mathrm{g} / \mathrm{g} & \text { microgram per gram } \\ \mathrm{mg} / \mathrm{kg} & \text { milligram per kilogram } \\ \mathrm{ppm} & \text { parts per million } \\ \mu \mathrm{m} & \text { micrometer } \\ \mathrm{Cl} & \text { condition index } \\ \mathrm{ERL} & \text { effects range-low } \\ \mathrm{ERM} & \text { effects range-median } \\ \mathrm{EPA} & \text { U.S. Environmental Protection Agency } \\ \text { ICP-OES } & \text { inductively coupled plasma-optical emission spectrophotometry } \\ \text { IRMS } & \text { isotopic ratio mass spectrophotometry } \\ \mathrm{MDL} & \text { method detection limit } \\ \mathrm{MLLW} & \text { mean low low water } \\ \mathrm{MRL} & \text { method reporting level } \\ \mathrm{NIST} & \text { National Institute of Standards and Technology } \\ \text { NPDES } & \text { National Pollutant Discharge Elimination System } \\ \text { PARWQCP } & \text { Palo Alto Regional Water Quality Control Plant } \\ \text { RWQCB } & \text { California Regional Water Quality Control Board } \\ \text { SFEI } & \text { San Francisco Estuary Institute } \\ \text { USGS } & \text { U.S. Geological Survey }\end{array}$




\section{Near-Field Receiving-Water Monitoring of Trace Metals and a Benthic Community Near the Palo Alto Regional Water Quality Control Plant in South San Francisco Bay, California-2017}

By Daniel J. Cain, Janet K. Thompson, Francis Parchaso, Sarah Pearson, Robin Stewart, Mathew Turner, David Barasch, Ané Slabic, and Samuel N. Luoma

\section{Executive Summary of Past Findings}

U.S. Geological Survey (USGS) personnel have assessed trace-metal concentrations in sediments and sediment-dwelling species since 1977 at an intertidal site in the vicinity of the discharge of the Palo Alto Regional Water Quality Control Plant (PARWQCP). They have also profiled that area's benthic community structure since 1974. Ancillary biotic and abiotic factors that could affect metal concentrations and benthic community structure - exotic species invasions, pelagic food availability, and weather anomalies - have also been measured during this time. Collectively, this dataset describes a long-term, detailed history of metal concentrations and benthic community dynamics at this site.

Initially, these studies found exceptionally high concentrations of silver $(\mathrm{Ag})$ and copper $(\mathrm{Cu})$ in mud-dwelling animals in this area (Luoma and Cloern, 1982), with strong seasonal variability (Luoma and others, 1985). Additional studies identified the PARWQCP as a point source for silver and copper and established the clam Macoma petalum as a biological indicator of metal exposure (Thomson and others, 1984). The annual mean concentrations of silver and copper in M. petalum were 104 milligrams per kilogram $(\mathrm{mg} / \mathrm{kg})$ and $282 \mathrm{mg} / \mathrm{kg}$, respectively, in 1980. These levels exceeded tissue concentrations reported in the literature for this species and were much greater than seen elsewhere in San Francisco Bay. Elevated metal concentrations coincided with reduced reproductive activity in M. petalum (Hornberger and others, 2000). Related studies supported the theory that elevated silver concentrations inhibited the development of reproductive tissue. The benthic community also showed signs of environmental stress during this time. Opportunistic organisms (capable of fast invasion and propagation in disturbed environments) dominated the community. These organisms thrived on the surface of the mud in tubes or as shelled animals, brooded their young, and fed on waterborne particles.

Concentrations of silver and copper in both sediments and clams declined significantly during the 1980s (for example, as low as $11 \mathrm{mg} / \mathrm{kg}$ silver and $35 \mathrm{mg} / \mathrm{kg}$ copper in M. petalum by the end of the decade) as the PARWQCP implemented more advanced wastewater treatment and source control programs. The downward trends in copper in sediments and in the tissues of M. petalum correlated with reduced copper discharge from the PARWQCP (Hornberger and others, 2000; data for silver loading were not available before 1989). Coincident with the decline in copper and silver in the sediment and clams, the reproductive activity of the clam greatly increased. The composition of the benthic community also shifted during this period. Opportunistic species became less dominant, and less opportunistic species became more persistent. Other environmental factors that vary seasonally and 
annually (for example, sediment composition, grain-size distribution, organic content, and ambient water salinity) were not associated with the observed temporal trends in metal concentrations, inferred metal effects on species, and benthic community changes. The only unidirectional change in an environmental factor during this period (1980-1990) was the decline in metal concentrations in discharge from the wastewater treatment plant (Hornberger and others, 2000). The temporal coincidence between metals discharge from the plant, metal concentrations in sediment and tissues of M. petalum at the site, and the observed biological responses suggested that the recession in metal exposure was principally responsible for the observed biological recovery.

Following the significant reductions in the 1980s, concentrations of silver and copper in sediments continued to decline, although much more gradually. Silver concentration of sediment remains greater than what may be considered the natural regional background $(0.09 \pm 0.02 \mathrm{mg} / \mathrm{kg})$ (Hornberger and others, 1999). This persistent, low level of contamination likely derives from silver introduced to the site before the 1990s. The concentrations of silver and copper in M. petalum have fluctuated as much as four-fold. Silver concentrations have declined slightly since the 1990s while $\mathrm{Cu}$ concentrations have remained fairly stable. At least some of the variation in silver and copper concentrations of $M$. petalum appears related to annual growth and reproductive cycles independently of exposure. Contemporary metal concentrations in sediments and tissue of $M$. petalum likely reflect a combination of factors, including inputs from the PARWQP and other regional sources, cycling of contaminants stored within sediments, and regionally-scaled physical and biogeochemical processes controlling the distribution and bioavailability of metals.

As concentrations of silver and copper in M. petalum declined, reproductive activity increased both in terms of the percentage of individuals that were in a reproductively active stage and the frequency of reproductive activity during the year (Hornberger and others, 2000). Overall, the reproductive status of the population has improved and stabilized over the more than 25 years (1990 to present) of reduced exposure to silver and copper at the site.

Over the same period, the composition of the infaunal community shifted from a dominance of surface-dwelling, brooding species to species with various life-history characteristics. In particular, species that lay their eggs in the mud and feed by burrowing through and consuming the mud, which were rare in the community in the 1970s and 1980s, have increased in abundance. This pattern continued through 2007, with the less opportunistic species becoming more dominant in abundance. A disturbance occurred on the mudflat in early 2008 (possible causes include sediment accretion or freshwater inundation) that resulted in the loss of the benthic animals, except for those deep-dwelling animals like $M$. petalum. Animals returned to the mudflat within two months of the event, however, which indicated that the disturbance was not due to a persistent toxin or to anoxia. Benthic community data in 2009 showed that the animals that returned to the mudflat were those that can respond successfully to a physical, nontoxic disturbance. The most recent community surveys showed a mix of animals that consume the sediment, filter feed, brood their young, and have pelagic larvae that must survive life on the sediment at a young age. The 2008 defaunation event allowed for an examination of the response of the community to a natural disturbance and a comparison of this recovery to the longterm recovery observed in the 1970s, when the decline in sediment pollutants was the dominating factor. Today, the community at this site is very similar to the benthic community observed by Thompson and Parchaso (2012) throughout south San Francisco Bay: although small filter feeding species are numerically dominant, there is a significant proportion of the community that feeds on surface and subsurface sediment particles, a feature of community structure that is not present where sediments have high concentrations of toxicants. 
When the trace metal study started in the late 1970s, the site was already heavily contaminated. Although the authors assume that the biological conditions reflected the consequences of elevated metal exposures, there is a scarcity of preexisting data to evaluate impacts owing to elevated metals, particularly over decadal time scales. However, the long-term record contained in this study provides a unique opportunity to document biological response when the stress of metal exposure is relaxed. The data make a compelling case that the mitigation of silver and copper in wastewater effluent during the 1980s allowed for biological recovery and the establishment of a more diverse and stable infaunal community.

\section{Abstract}

Trace-metal concentrations in sediment and in the clam Macoma petalum (formerly reported as Macoma balthica), clam reproductive activity, and benthic macroinvertebrate community structure were investigated in a mudflat 1 kilometer south of the discharge of the Palo Alto Regional Water Quality Control Plant (PARWQCP) in south San Francisco Bay, Calif. This report includes the data collected by U.S. Geological Survey (USGS) scientists for the period January 2017 to December 2017. These append to long-term datasets extending back to 1974. A major focus of the report is an integrated description of the 2017 data within the context of the longer, multi-decadal dataset. This dataset supports the City of Palo Alto's Near-Field Receiving Water Monitoring Program, initiated in 1994.

Significant reductions in silver and copper concentrations in sediment and M. petalum occurred at the site in the 1980s following the implementation by PARWQCP of advanced wastewater treatment and source control measures. Since the 1990s, concentrations of these elements appear to have stabilized at concentrations somewhat above silver $(\mathrm{Ag})$ or near copper $(\mathrm{Cu})$ regional background concentrations. Data for other metals, including chromium $(\mathrm{Cr})$, mercury $(\mathrm{Hg})$, nickel $(\mathrm{Ni})$, selenium $(\mathrm{Se})$, and zinc (Zn), have been collected since 1994. Over this period, concentrations of these elements have remained relatively constant, aside from seasonal variation that is common to all elements. In 2017, concentrations of silver and copper in $M$. petalum varied seasonally in response to a combination of sitespecific metal exposures and annual growth and reproduction, as reported previously. Seasonal patterns for other elements, including $\mathrm{Cr}, \mathrm{Ni}, \mathrm{Zn}, \mathrm{Hg}$, and $\mathrm{Se}$, were generally similar in timing and magnitude as those for $\mathrm{Ag}$ and $\mathrm{Cu}$. This record suggests that legacy contamination and regional-scale factors now largely control sedimentary and bioavailable concentrations of silver and copper, as well as other elements of regulatory interest, at the Palo Alto site.

Analyses of the benthic community structure of a mudflat in south San Francisco Bay over a 40year period show that changes in the community have occurred concurrent with reduced concentrations of metals in the sediment and in the tissues of the biosentinel clam, M. petalum, from the same area. Analysis of $M$. petalum shows increases in reproductive activity concurrent with the decline in metal concentrations in the tissues of this organism. Reproductive activity is presently stable (2017), with almost all animals initiating reproduction in the fall and spawning the following spring. The entire infaunal community has shifted from being dominated by several opportunistic species to a community where the species are more similar in abundance, a pattern that indicates a more stable community that is subjected to fewer stressors. In addition, two of the opportunistic species (Ampelisca abdita and Streblospio benedicti) that brood their young and live on the surface of the sediment in tubes have shown a continual decline in dominance coincident with the decline in metals; both species had shortlived rebounds in abundance in 2008, 2009, and 2010 and showed signs of increasing abundance in 2017. Heteromastus filiformis (a subsurface polychaete worm that lives in the sediment, consumes sediment and organic particles residing in the sediment, and reproduces by laying its eggs on or in the sediment) showed a concurrent increase in dominance and, in the last several years before 2008, showed 
a stable population. H. filiformis abundance increased slightly in 2011-2012 and returned to pre-2011 numbers in 2017. An unidentified disturbance occurred on the mudflat in early 2008 that resulted in the loss of the benthic animals, except for deep-dwelling animals like M. petalum. However, within two months of this event animals returned to the mudflat. The resilience of the community suggested that the disturbance was not due to a persistent toxin or anoxia. The reproductive mode of most species that were present in 2017 is reflective of species that were available either as pelagic larvae or as mobile adults. Although oviparous species were lower in number in this group, the authors hypothesize that these species will return slowly as more species move back into the area. The use of functional ecology was highlighted in the 2017 benthic community data, which showed that the animals that have now returned to the mudflat are those that can respond successfully to a physical, nontoxic disturbance. Today, community data show a mix of species that consume the sediment, or filter feed, have pelagic larvae that must survive landing on the sediment, and those that brood their young. USGS scientists view the 2008 disturbance event as a response by the infaunal community to an episodic natural stressor (possibly sediment accretion or a pulse of freshwater), in contrast to the long-term recovery from metal contamination. We will compare this recovery to the long-term recovery observed after the 1970 s when the decline in sediment pollutants was the dominating factor.

\section{Introduction}

Determining spatial distributions and temporal trends in trace metals in sediments and benthic organisms is common practice for monitoring environmental contamination. These data can be the basis for assessing metal exposure, the potential for adverse biological effects, and the response to regulatory or management actions (Suter, 2001). Another common method of environmental monitoring is to examine the community structure of sediment-dwelling benthic organisms (Simon, 2002). Spatial and temporal changes in community structure reflect the integrated response of resident species to environmental conditions, although the underlying cause(s) for the response may be difficult to identify and quantify. Together, measurements of metal exposure and biological response can provide a more complete view of anthropogenic disturbances and the associated effects on ecosystem health.

Sediment particles can strongly bind metals, effectively repartitioning them from solution to a solid phase. As a result, sediments may accumulate and retain metals released to an aquatic environment. Sediment cores provide a historical record of metal inputs that can reveal anthropogenic influences (Förstner and Wittmann, 1979). Specifically, studies of sediment cores in San Francisco Bay chronicled metal inputs and suggested that legacy contamination can remain a chronic source of metals to the system owing to sediment mixing and redistribution (Hornberger and others, 1999; Van Geen and Luoma, 1999). Metals in sediments are also indicative of the level of exposure of benthic animals to metals through contact with, and ingestion of, bottom sediments and suspended particulate materials. However, physical and geochemical conditions of the sediment affect the biological availability of the bound metals. Assimilation of bioavailable sediment-bound metal by digestive processes and the contribution of this source of metals relative to metals in the aqueous phase are not well understood. Thus, in order to better estimate bioavailable metal exposures, the tissues of the organisms themselves may be analyzed for trace metals (Phillips and Rainbow, 1993). Different species concentrate metals to different degrees. However, if one species is analyzed consistently, the results can be used to indicate trace-element exposures to the local food web.

Contaminants can adversely affect benthic organisms at several organizational levels. For example, responses to a pollutant at the cellular or physiological level of an individual can cause changes at the population level, such as reductions in growth, survival, and reproductive success (Newman, 1998). Community-level responses to population-level impairment can include overall shifts 
in diversity and species abundance, favoring metal-tolerant species, which can result in changes in predator/prey interactions and competition for available resources. Changes in the benthic community can ultimately result in changes at the ecosystem level due to that community's importance as primary consumers in the cycling of carbon in aquatic environments (Alpine and Cloern [1992] provides a local example).

In all aquatic environments, benthic organisms may be exposed to contaminants at all life stages through a variety of routes - sediment, water, and food (Wang and Fisher [1999] provides a summary of the potential transport of trace elements through food). Toxicant exposure is related to contaminant concentration as well as duration. Even at fairly low contaminant levels, long-term exposure can affect benthic organisms (Long and others, 1995). The added complexity of synergistic or antagonistic effects between different contaminants, and between contaminants and natural stressors, makes causal relationships difficult to identify and quantify, even on a site-specific basis. However, a time-integrated picture of ecosystem response to contaminant loading can be provided by field studies that link changes in exposure at multiple time scales (in this case seasonal to decadal) to changes at individual, population, and community levels. Data from such studies support surveillance and compliance of water-quality objectives.

Permits issued by the California Regional Water Quality Control Board (RWQCB) under the National Pollutant Discharge Elimination System (NPDES) to the Palo Alto Regional Water Quality Control Plant (PARWQCP) (fig. 1), requires a prescribed self-monitoring program. In addition, the City of Palo Alto augments its own monitoring program with data collected by the U.S. Geological Survey (USGS). The USGS monitoring protocols have been designed to be compatible with or complementary to the RWQCB's Regional Monitoring Program. In this report, the USGS monitoring study is described, and data collected during 2017 are presented within the context of more than 40 years of previous data collections and investigations by the USGS at this inshore location.

The data collected during this study include trace-metal concentrations in sediments and clams, clam reproductive activity, and benthic community structure (based on taxonomic analyses). These data and those reported earlier (for example, Luoma and others, 1991, 1995a, 1996; Hornberger and others, 2000; Thompson and others, 2002; Shouse and others, 2003, 2004; Moon and others, 2005; Cain and others, 2006; Dyke and others, 2012, 2014) were used to meet the following objectives:

- Provide data to assess seasonal and annual trends in trace-element concentrations in sediments and clams, reproductive activity of clams, and benthic community structure at a site designated in the RWQCB's self-monitoring program guidelines for PARWQCP.

- Present the data within the context of historical changes in south San Francisco Bay and within the context of other locations in the Bay published in the international literature.

- Coordinate inshore receiving water monitoring program for PARWQCP and provide data compatible with relevant aspects of the regional monitoring program. The near-field data will augment the regional monitoring program as suggested by the RWQCB.

- Provide data that could support other south San Francisco Bay management issues or programs, such as total maximum daily loading (TMDL) targets.

Despite the complexities inherent in monitoring natural systems, the adopted approach has been effective in relating changes in near-field contamination to changes in reproductive activity of a clam (Hornberger and others, 2000) and in benthic community structure (Kennish, 1998). This study, with its basis in historical data, provides a rare multi-decadal context within which future environmental changes can be assessed.

Metal concentrations were monitored in sediments and a resident clam species, Macoma petalum. Analysis of trace-metal concentrations in the sediments over time provides a record of metal 
contamination of the site. The concentration and bioavailability of sediment-bound metals are affected by physical and geochemical factors (Thomson-Becker and Luoma, 1985; Luoma and others, 1995b). Thus, ancillary data, including grain-size distribution, organic carbon, aluminum and iron content of the sediment, regional rainfall, and surface salinity were collected to interpret seasonal, annual, and interannual variation in metal concentrations. The tissue of $M$. petalum provides a direct measure of exposure to bioavailable metals.

Biological response of the benthic community to metal exposure was examined at three levels of organization: individual, population, and community. At the individual level, concentrations of metals in the tissues of $M$. petalum were compared with physiological indicators. Two common animal responses to environmental stress are reduced growth and reproductive activity. Growth and reproduction in $M$. petalum occur on fairly regular seasonal cycles. Seasonally, a clam of a given shell length will increase somatic tissue weight as it grows during the late winter and spring (Cain and Luoma, 1990). Reproductive tissue increases during the early stages of reproduction and declines during and after spawning. These cycles can be followed with the condition index (CI), which is represented as the total soft-tissue weight of a clam standardized to shell length, and is indicative of the physiological condition of the animal (Cain and Luoma, 1990). Inter-annual differences in growth and reproduction, expressed in the CI, are affected by the availability and quality of food, as well as other stressors, such as pollutant exposure and salinity extremes. Hornberger and others (2000) showed that reproductive activity of $M$. petalum increased with declining metal concentrations in animals from this location. Therefore, CI and reproductive activity of $M$. petalum appear to be useful indicators of physiological stress by pollutants at this location and continue to be monitored in this study.

At the population level, trends of the dominant benthic species were examined to see if certain species have been more affected than others by environmental change. It has been shown that most taxonomic groups have species that are sensitive to elevated silver (Luoma and others, 1995b) and that some crustacean and polychaete species are particularly sensitive to elevated sedimentary copper (Rygg, 1985; Morrisey and others, 1996). In addition, the benthic community was examined for changes in structure - that is, shifts in the species composition of the macroinvertebrate community that typically result in a change in the function of that community. The authors hypothesized that a shift in community composition and potentially in the function of the benthic community in the ecosystem would result from changes in the concentrations of either specific metals or a combination of contaminants for several reasons. First, prior studies have shown that south San Francisco Bay benthic communities were dominated by opportunistic species in the 1980s (Nichols and Thompson, 1985a). These opportunistic species might become less dominant as environmental stressors decrease. Second, environmental pollutants may differentially affect benthic species that use different feeding and reproductive modes. An intertidal mudflat community, such as this study site, should include a combination of species that feed on particles in the water column, on settled and buried food particles in the mud, and on other organisms. The absence of any one of these feeding groups may impose limitations on species as a result of environmental stressors that target specific feeding groups. For example, pollutants attached to sediment particles are more likely to affect species that consume the sediment as part of their feeding mode or those species that lay their eggs in the sediment.

Previous analysis of this community has shown no correlation between changes in the community and measured environmental parameters (salinity, air and water temperature, delta outflow, precipitation, chlorophyll a, sediment total organic carbon, and biological oxygen demand; Shouse, 2002). Therefore, the community data are compared only to trace-metal data in this report.

The Palo Alto site (PA) includes the benthic community sampling site and the M. petalum and sediment sampling site, both adjacent to Sand Point in Palo Alto Baylands Nature Preserve on a mudflat 
on the western shore of San Francisco Bay (fig. 1). The site is 1 kilometer southeast of the intertidal discharge point of the PARWQCP. The sampling locations are approximately 12 meters $(\mathrm{m})$ from the edge of the marsh and 110 centimeters $(\mathrm{cm})$ above mean low low water (MLLW).

The sediment and biological samples from this location reflect a response of the receiving waters to the effluent just beyond the location of discharge. Earlier studies (Thomson and others, 1984) have shown that dyes, natural organic materials in San Francisquito Creek, and waters in the PARWQCP discharge move predominantly south toward Sand Point, thereby affecting the mudflats in the vicinity of Sand Point. Thomson and others (1984) showed that San Francisquito Creek and the Palo Alto Yacht Harbor were minor sources of most trace elements compared to the PARWQCP. Based on spatial and temporal trends of copper, silver, and zinc in clams and sediments, the PARWQCP appeared to be the primary source of elevated metal concentrations at the PA site in the spring of 1980 (Thomson and others, 1984; Cain and Luoma, 1990). Metal concentrations in sediments and clams (M. petalum), especially silver and copper, have declined substantially since the original studies as more efficient treatment processes and source controls were employed (Hornberger and others, 2000). Frequent sampling each year was necessary to characterize those trends because there was significant seasonal variability (Luoma and others, 1985; Cain and Luoma, 1990). This report characterizes data for the year 2017, thereby extending the long-term record at this site.

\section{Methods}

\section{Sampling Frequency and Duration}

In dynamic ecosystems such as San Francisco Bay, the environmental effects of anthropogenic stressors are difficult to distinguish from natural seasonal or life-cycle changes. Sustained sampling at frequent intervals can characterize seasonal patterns, capture episodic events, and identify longer term trends, thereby increasing the probability that anthropogenic effects can be identified. Analyses of early community data (1974-1983; Nichols and Thompson, 1985a, b) showed that benthic samples need to be collected at monthly to bimonthly intervals to distinguish between natural and anthropogenic effects. Therefore, data reported herein are based on samples collected on a monthly to bimonthly basis from the exposed mudflat at low tide between January and December. Samples collected in the field include surface sediment, the deposit-feeding clam M. petalum, surface water, and sediment cores for community analysis. Usually, surface water, surface sediment, and M. petalum were not collected during the months of July, August, and November. Cores for benthic community analyses were not collected during the months May and July. Data on sediments, M. petalum, and surface water have been collected continuously since 1977, while community data were collected during 1974-1990 and 1998 to the present (2017).

During the period 1977-1980, the sampling frequency and composition of M. petalum samples differed from the current design. Specifically, samples were collected more frequently to meet different study objectives and individual clams were analyzed instead of the current practice of compositing clams of similar size (see below). To harmonize the earlier and later datasets, monthly means for the 1977-1980 period were recalculated as follows. Where more than one sample was collected within a single month of a given year, the mean of those samples was calculated. Monthly data for a given year were averaged, producing a grand annual mean with the associated standard error of the mean. This recalculation of the data changed the 1977-1980 annual means for $\mathrm{Ag}$ and $\mathrm{Cu}$ slightly. For example, the annual concentration of $\mathrm{Ag}$ in M. petalum in 1980 was previously reported as $105 \mathrm{mg} / \mathrm{kg}$ (Cain and others, 2017). The recalculated concentration is $104 \mathrm{mg} / \mathrm{kg}$. 


\section{Measurements of Metal Exposure}

Metal concentrations in surficial sediments and in the soft tissues of $M$. petalum were interpreted as indicative of metal exposure to the broader benthic community. The collection and preparation of sediment and M. petalum samples have been described in detail, previously (see, for example, Dyke and others, 2014). The following is an overview of those procedures.

Sediment

Sediment samples were scraped from the visibly oxidized (brownish) surface layer (top 1-2 cm) of mud and later that day sieved through a 100-micrometer $(\mu \mathrm{m})$ mesh polyethylene screen with distilled water to remove large grains that might bias interpretation of concentrations. The mesh size was chosen to match the largest grains typically found in the digestive tract of M. petalum. All chemical data reported herein were determined from the fraction that passed through the sieve $(<100 \mu \mathrm{m})$, termed the "silt/clay fraction."

The percentage silt/clay fraction of sediment samples was determined to provide some comparability with bulk sediment determinations such as that employed in the Regional Monitoring Program (San Francisco Estuary Institute, 1997). The sediment that did not pass through the sieve $(>100$ $\mu \mathrm{m})$ _ termed the sand fraction — was collected, as was the silt/clay fraction $(<100 \mu \mathrm{m})$ (see above). Each fraction was dried to constant weight, and their percent contributions to the bulk sample were determined gravimetrically.

The silt/clay fraction was subsampled to provide replicates weighing 0.4 to 0.6 grams $(\mathrm{g})$. These were redried $\left(70^{\circ} \mathrm{C}\right)$, reweighed, and then digested by hot acid reflux $(10$ milliliters [mL] of 16 normal $[\mathrm{N}]$ nitric acid). This method provides a "near-total" extraction of metals from the sediment and is comparable to the recommended procedures of the U.S. Environmental Protection Agency (EPA) and to the procedures employed in the regional monitoring program. Another set of replicate subsamples from the silt/clay fraction were directly extracted with $12 \mathrm{~mL}$ of $0.6 \mathrm{~N}$ hydrochloric acid $(\mathrm{HCl})$ for 2 hours at room temperature. This partial extraction method extracts metals bound to sediment surfaces and is operationally designed to obtain a crude chemical estimate of bioavailable metal.

\section{Clam Tissue}

Specimens of M. petalum were collected by hand on each sampling occasion. Typically, 60-120 individuals were collected, representing a range of sizes (shell length).

In the laboratory, the clams were removed from the containers and gently rinsed with deionized water to remove sediment. Clams were immersed in seawater diluted with deionized water as necessary to the equivalent of ambient salinity, and moved to a constant-temperature room $\left(12 \pm 1^{\circ} \mathrm{C}\right)$ for 48 hours to allow for the egestion of sediment and undigested material from their digestive tracts.

\section{Sample Preparation for Metal Analysis, Excluding Mercury and Selenium}

The shell length of each clam was measured with electronic calipers and recorded digitally. Clams were separated into 1- or 2-millimeter (mm) size classes (for example, 10.00-10.99 mm or $10.00-11.99 \mathrm{~mm}$ ). The soft tissues from all of the individuals within a given size class were dissected from the shell and collected in preweighed 20-mL screw-top borosilicate glass vials to form a single composite sample for elemental analysis. The vials were transferred to a convection oven $\left(70 \pm 1^{\circ} \mathrm{C}\right)$. After the tissues were dried to constant weight, they were digested by reflux in subboiling $16 \mathrm{~N}$ nitric acid. The tissue digests were then dried and metals resolubilzed in $0.6 \mathrm{~N} \mathrm{HCl}$ for trace-metal analysis. 


\section{Analytical, Excluding Mercury and Selenium}

Sediment and tissue concentrations of aluminum $(\mathrm{Al})$, chromium $(\mathrm{Cr})$, copper $(\mathrm{Cu})$, iron $(\mathrm{Fe})$, nickel (Ni), silver (Ag), and zinc ( $\mathrm{Zn}$ ) were determined using inductively coupled plasma optical emission spectrophotometry (ICP-OES). Samples and standard reference materials (see below) were filtered $(0.45 \mu \mathrm{m})$ prior to analysis. Analytical ICP-OES results are available upon request.

\section{Sample Preparation and Analysis for Mercury and Selenium}

Approximately 40 clams were selected from each collection. The only criterion for selection was that the range of sizes (shell length) within this group was representative of the larger collection. Otherwise, the selection of individuals was random. Selected individuals were grouped according to size to form 3 composites, each containing a minimum of $\sim 1.25 \mathrm{~g}$ wet weight. To meet this requirement, especially for the smaller clams, the 1-mm-size classes were usually combined to form broader size classes (within 3-4 mm of each other, as appropriate). Once the composites were formed, the clams were dissected as described above, and the soft tissue was placed into preweighed $30-\mathrm{mL}$ screw-top polycarbonate vials. These vials were closed and temporarily transferred to a freezer $\left(-20^{\circ} \mathrm{C}\right)$. The tissue sample was partly thawed and homogenized with a high-speed tissue homogenizer. Once homogenized the samples were refrozen $\left(-80^{\circ} \mathrm{C}\right)$ and then freeze-dried.

Sediment samples for mercury and selenium analyses were prepared with the same methods used for other trace elements (described above and in previous reports, for example Dyke and others [2014]).

Tissue and sediment samples were subsampled and analyzed for total mercury by acid-digestion, $\mathrm{BrCl}$ oxidation, purge and trap, and cold vapor atomic fluorescence spectrometry according to the EPA Method 1631, Revision E (2002), and for selenium by acid digestion, hydrogen peroxide oxidation, hydride generation inductively coupled plasma mass spectrometry (HG-ICP-MS) according to a method modified from Liber (2011) and Elrick and Horowitz (1985).

\section{Quality Assurance}

All glass and plastic materials used in the collection, preparation, and storage of samples were first cleaned thoroughly to remove metal contamination. Cleaning consisted of sequential immersion in a detergent bath for at least 24 hours, a rinse in deionized water, then immersion in a 10 -percent $\mathrm{HCl}$ wash for at least 24 hours, followed by a thorough rinse in double-deionized water (approximately 18 mega-ohm [M $\Omega-\mathrm{cm}]$ resistivity). Materials were dried in a dust-free positive-pressure environment, sealed, and stored in a dust-free cabinet.

Samples prepared for ICP-OES analysis (that is, all elements except selenium and mercury) were accompanied by procedural blanks and standard reference materials (SRMs) issued by the National Institute of Standards and Technology (NIST). Analysis was preceded by instrument calibration, followed by quality-control checks with prepared quality-control standards before, during (approximately every 10 samples), and after each analytical run. Metal recoveries of sediment digests were evaluated with NIST 2709a San Joaquin soils and NIST 2711a Montana II Soil (appendix 1). Metal recoveries for soft tissue digests were evaluated with NIST 2976 Mussel Tissue and NIST 1566b Oyster Tissue (appendix 2). Results were consistent within methods. Recoveries of $\mathrm{Ag}, \mathrm{Cu}, \mathrm{Ni}$, and $\mathrm{Zn}$ from NIST 2709a and 2711a by the near-total extraction method were generally consistent with those reported by NIST for EPA methods 200.7 and 3050B, whereas the near-total extraction method recovered a greater percentage of total $\mathrm{Al}, \mathrm{Cr}$, and $\mathrm{Fe}$. Recoveries of elements in biological SRMs were consistently greater than 80 percent. 
Analytical precision of mercury and selenium methods were determined in sample splits (appendix 3). Coefficients of determination ranged from 0.1 to 2.3 percent.

A variety of standard reference materials were prepared according to the method used for the determination of selenium and mercury. Observed concentrations fell within the range of certified values for these materials (appendix 4).

Method detection limits (MDL) and reporting levels (MRL) for ICP-OES methods were determined using the procedures outlined by Glaser and others (1981), Childress and others (1999), and U.S. Environmental Protection Agency (2004) (appendix 5). A full quality-assurance/quality-control plan is available upon request.

\section{Salinity}

A small volume (approximately $25 \mathrm{~mL}$ ) of water that had pooled on the surface of the mudflat was collected in a polypropylene bottle and returned to the laboratory, where it was measured for salinity with a handheld refractometer. Additionally, salinity is determined in a small volume (approximately 1-2 mL) of bay water that is collected from the body cavity of M. petalum. Salinity of the surface water sample and the body water sample consistently agreed within 3 parts per thousand (\%).

\section{Other Data Sources}

Precipitation data for San Francisco Bay are reported from a station at San Francisco International Airport (station identification SFF) and were obtained from the California Data Exchange Center (http://cdec.water.ca.gov/).

\section{Biological Response}

\section{Condition Index}

The condition index (CI) is a measure of the clam's physiological state derived from the relation between soft tissue weight and shell length and reported as the soft tissue dry weight (grams) for a clam of a particular shell length $(\mathrm{mm})$. Specifically, for each collection, the relation between the average shell length and tissue dry weight of the composites was fit with a linear regression, and from that regression, the tissue dry weight was predicted for a normalized shell length of $25 \mathrm{~mm}$ (Cain and Luoma, 1990).

\section{Reproductive Activity}

A minimum of 10 clams of varying sizes ( $\geq 10 \mathrm{~mm}$ shell length) were processed for reproductive activity concurrent with samples for metal analyses. Clams were immediately preserved in 10-percent formalin at the time of collection. The visceral mass of each clam was removed in the laboratory, stored in 70-percent ethyl alcohol, and then prepared using standard histological techniques. Tissues were dehydrated in a graded series of alcohol, cleared in toluene (twice for 1 hour each), and infiltrated in a saturated solution of toluene and Paraplast $\AA$ for 1 hour, and two changes of melted Tissuemat $\AA$ for 1 hour each. Samples were embedded in Paraplast ${ }^{\circledR}$ in a vacuum chamber and then thin sectioned $(10 \mu \mathrm{m})$ using a microtome (Weesner, 1960). Sections were stained with Harris' hematoxylin and eosin and examined with a light microscope. Each individual was characterized by size (length in $\mathrm{mm}$ ), sex, developmental stage, and condition of gonads, thus allowing each specimen to be placed in one of five qualitative classes of gonadal development (Parchaso, 1993). 


\section{Community Analysis}

Samples for benthic community analysis were collected with a hand-held core, $8.5-\mathrm{cm}$ in diameter and $20-\mathrm{cm}$ deep. Three replicate samples were taken arbitrarily, within a square-meter area, during each sampling date.

Benthic community samples were washed and retained on a $500-\mu \mathrm{m}$ screen, fixed in 10 -percent formalin, and then later preserved in 70-percent ethanol. Samples were stained with rose bengal solution. All animals in all samples were sorted to species level where possible, and individuals for each species were enumerated. However, some groups, such as the oligochaetes, are still not well defined in the Bay, and hence were not enumerated to the species level. Taxonomic work was performed in conjunction with a private contractor familiar with the taxonomy of San Francisco Bay invertebrates (Susan McCormick, Colfax, Calif.). McCormick also compared and verified her identifications with previously identified samples.

\section{Statistical Analysis}

Data collected during 2017 are reported as monthly means with associated standard deviations (STD) and annual (grand) means of monthly means with associated standard error mean (SEM). Correlations are reported as the Pearson product-moment coefficient unless otherwise stated. Groups (such as annual metal concentrations) were tested with ANOVA and Kruskal-Wallis. Transformations of data for statistical analysis are explained in the results. Differences with a Type I error rate $\alpha \leq 0.05$ were considered significant. Statistical analyses were performed with Statistica v. 13 (Statsoft). Throughout the report, metals data are illustrated to represent inter-annual variation for the period 19942017 and intra-annual variation over the past 5 years. The general pattern of seasonal variation was based on monthly means of all samples collected over the period of record (typically 1994-2017).

\section{Results}

\section{Salinity}

Surface-water salinity in the bay is related to, and roughly the inverse of, the seasonal weather pattern in northern California, which is characterized by a winter rainy season that has been defined as months with rainfall amounts greater than 0.25 inches (November through April) and a summer dry season (May through October). Total precipitation measured at station SFF in 2017 was 26.5 inches. (http://cdec.water.ca.gov/) (fig. 2). Salinity varied between 5 and 23\%o during 2017 (fig. 3).

\section{Sediments}

Surficial sediment collected in this study is dominated by silt- and clay-sized particles $<100 \mu \mathrm{m}$, typically constituting 50-90 percent of the sampled sediment on a weight basis. These fine sediments provide large surface areas for metal sorption. Metal concentrations vary as a function of the ratio of surface area to volume of a particle and thus tend to track the percentage of fine particles. The percentage of fine particles displays an annual periodicity as do aluminum and iron concentrations (fig. $4 C$ ), and other metals considered in this study (not illustrated). Indeed, for all metals considered in this study, other than $\mathrm{Hg}$ and total organic carbon (TOC), correlations with the percentage of fines were highly significant ( $\mathrm{r} \geq 0.87$, appendix 6). Thomson-Becker and Luoma (1985) suggested that this intraannual variation in metal concentration is related to changes in the size distribution of sediment particles caused by allochthonous inputs and deposition of fine-grained particles in the winter and their subsequent wind-driven resuspension in the summer and fall. 
Chromium and nickel are highly enriched in some geologic formations within the watershed. For example, in north San Francisco Bay, studies of sediment cores indicated that concentrations of these elements similar to those reported here were derived from natural geologic inputs (Hornberger and others, 1999; Topping and Kuwabara, 2003). At Palo Alto, annual concentrations of chromium in surface sediment varied between 105 and $163 \mathrm{mg} / \mathrm{kg}$ and nickel concentrations varied between 72 and $100 \mathrm{mg} / \mathrm{kg}$ (fig. 5). In 2017, concentrations were $120 \pm 12$ and $92 \pm 9 \mathrm{mg} / \mathrm{kg}$ for chromium and nickel, respectively (table 1). As with other metals, chromium and nickel concentrations varied seasonally which may reflect seasonal changes in the particle size distribution of sediments described above and inputs from the surrounding watershed.

Concentrations of copper and zinc in sediments are shown with a sediment quality guideline set by the National Oceanic and Atmospheric Administration (Long and others, 1995) in figures 6 and 7. Long and others (1995) defined the ERL (effects range-low) as the concentration below which the incidence of adverse effects on sensitive species is low ( $<10$ percent). The ERLs for copper and for zinc are $34 \mathrm{mg} / \mathrm{kg}$ and $150 \mathrm{mg} / \mathrm{kg}$, respectively. For most of the record, copper concentration has exceeded the ERL on an annual basis (fig. 6). In 2017, the average annual copper concentration was $30 \pm 1$ (SEM) $\mathrm{mg} / \mathrm{kg}$ (fig. 6, table 1). The partial extractions represent approximately 42 percent of the copper recovered in the near-total digest. Over the period 1990 to 2017, copper concentrations have gradually declined $(\mathrm{p}<0.05)$. Near-total and partially extractable zinc concentrations were below the zinc ERL $(150 \mathrm{mg} / \mathrm{kg})$ for the entire record (fig. 7, table 1) on an annual basis. Exceedances of near-total zinc within some years typically occurred during the winter season (for example, 2015). In 2017, the average annual zinc concentration was $112 \pm 4 \mathrm{mg} / \mathrm{kg}$ with a maximum concentration of $124 \mathrm{mg} / \mathrm{kg}$ in April and $127 \mathrm{mg} / \mathrm{kg}$ in December.

The annual average of silver extracted from sediments using the partial-extraction method has varied from a high of $1.62 \mathrm{mg} / \mathrm{kg}$ in 1979 to a low of $0.20 \mathrm{mg} / \mathrm{kg}$ in 2008-2009. During the 1980s, concentrations fell dramatically, but since then they have been fairly stable. In 2017, silver concentrations averaged $0.21 \pm 0.01 \mathrm{mg} / \mathrm{kg}$. During 2017, concentration maxima were observed in April and October $(0.25 \mathrm{mg} / \mathrm{kg})$, and minima occurred in March, June, and September $(0.17-0.18 \mathrm{mg} / \mathrm{kg})(\mathrm{fig}$. 8 , table 1).

Mercury and selenium concentrations in sediment from Palo Alto do not exhibit any obvious long-term trends (fig. 9). The median mercury concentration of the annual means is $0.29 \mathrm{mg} / \mathrm{kg}$, with 90 percent of the values falling between 0.24 and $0.33 \mathrm{mg} / \mathrm{kg}$. Concentrations occasionally exceeded 0.40 $\mathrm{mg} / \mathrm{kg}$ (in 2004 and 2015). During 2017, $\mathrm{Hg}$ averaged $0.29 \pm 0.02 \mathrm{mg} / \mathrm{kg}$ (fig. 9, table 1) with the minimum in June $(0.22 \mathrm{mg} / \mathrm{kg})$ and the maximum in December $(0.35 \mathrm{mg} / \mathrm{kg})$. On an annual basis, sedimentary selenium has varied between 0.30 and $0.79 \mathrm{mg} / \mathrm{kg}$ with no sustained temporal trend over the period of the record. In 2017, selenium varied seasonally, with higher concentrations in the early part of the year (from $0.52 \mathrm{mg} / \mathrm{kg}$ in January to $0.52 \mathrm{mg} / \mathrm{kg}$ in April) and then receded to 0.36-0.48 $\mathrm{mg} / \mathrm{kg}$ in June through December (fig. 9, table 1). For the year, selenium concentrations averaged $0.46 \pm 0.03 \mathrm{mg} / \mathrm{kg}$.

\section{Clam Tissue}

Metal concentrations in the soft tissues of $M$. petalum reflect a combination of metal exposures from water and food and the diluting and concentrating effects of gaining and losing tissue mass associated with annual growth and reproductive cycles (Cain and Luoma, 1990). Growth and reproductive cycles are reflected in the condition index (CI). Data on the CI fluctuate seasonally and annual cycles differ in magnitude (fig. 10A). Condition index values typically increase through winter to a maximum in the spring (pre-spawning period) then taper off through summer/fall (figs. 10B, $C$ ). The 
pattern of seasonal variation of CI in 2017 was typical for the record, although the spring growth/reproductive period was markedly weak (fig. 10B). This is reflected in the annual average CI for 2017 (107 $\pm 20 \mathrm{mg}$ ) (fig. 10A, table 2).

Exposures to copper and silver at Palo Alto are of special interest because of the high tissue concentrations observed at this site in the past (figs. 11, 12, appendix 7). During 1977-1990, the ranges in annual concentrations of copper and silver were $35-282 \mathrm{mg} / \mathrm{kg}$ and $7.7-104 \mathrm{mg} / \mathrm{kg}$, respectively. Since 1990, concentrations have been considerably lower (table 2); median concentrations for copper and silver are $33 \mathrm{mg} / \mathrm{kg}$ and $3.1 \mathrm{mg} / \mathrm{kg}$, respectively. Annual silver concentrations declined slightly over this period $(\mathrm{r}=-0.63, \mathrm{p}<0.001)$; however, they correlated negatively with the $\mathrm{CI}$, suggesting that the temporal trend in silver was at least in part a manifestation of the physiological state of the clam. The amplitude of the CI from one year to the next can affect inter-annual variation in metal concentrations. The increase in copper (fig. 11) and silver (fig. 12) in 2017 coincides with the fairly low CI.

Intra-annual variations in copper and silver concentrations in clam soft tissues display a consistent seasonal signal characterized by fall/winter maxima and spring/summer minima. The amplitude of this seasonal cycle varies from year to year (figs. $11 B$ and $12 B$ ). These patterns are correlated with the growth and reproductive cycles, as discussed above. For example, over the period of 1994 to 2017, the seasonal variations in copper and the CI varied inversely of one another ( $\mathrm{r}=-0.98$, $\mathrm{p}<0.001)$ and were of similar magnitude, suggesting that variations in tissue weight driven by growth and reproduction and tissue copper concentrations - as well as other elements - are coupled (fig. $11 \mathrm{C}$ ).

As with copper and silver, tissue concentrations of chromium (fig. 13, table 2), nickel (fig. 13, table 2), and zinc (fig. 14, table 2) also exhibited annual cycles of variable magnitude throughout the record. None of these elements exhibit a clear temporal trend (either decreasing or increasing) in concentration. In 2017, the annual average chromium, nickel, and zinc concentrations were $3.19 \pm 0.41$, $5.64 \pm 0.37$, and $346 \pm 22 \mathrm{mg} / \mathrm{kg}$, respectively (table 2).

The average mercury concentration in M. petalum in 2017 was $0.57 \pm 0.12 \mathrm{mg} / \mathrm{kg}$ (fig. 15, table 2), which was the highest recorded annual concentration in the time series at the site. A long-term trend in mercury concentration is not evident, however (fig. 15A). Intra-annual variation of fall/winter maxima and spring/summer minima observed in the preceding 3 years was not evident in 2017. Instead, mercury concentrations increased over the course of the year, similar to selenium in clams (see below).

Selenium concentrations in M. petalum averaged $4.96 \pm 0.14 \mathrm{mg} / \mathrm{kg}$ in 2017 (fig. 16, table 2). The mean annual concentrations of selenium have been relatively low and stable since 2011. Intra-annual variation was less evident in 2017 with concentrations generally increasing over the year with the highest concentration observed in December $(5.56 \mathrm{mg} / \mathrm{kg})$ (fig. 16B, table 2).

\section{Reproduction of Macoma petalum}

As previously reported, reproductive output in $M$. petalum appeared to be impaired by high concentrations of silver in the tissue of this clam during the early part of the record (Hornberger and others, 1999; Shouse and others, 2003). The time series of reproductive activity shows that following the decline in silver during the 1980s reproductive output increased, and it has remained at relatively high levels. Unlike the earlier period, a high percentage of the animals were reproductively active at any one time, and they did not stay reproductively inactive for longer than a month or two. Moreover, normal seasonal cycling of reproduction-beginning in the fall and continuing through the following spring-is evident (figs. 17, 18, appendix 8). 


\section{Benthic Community}

Estimates of species diversity and total animal abundance are fundamental metrics that are used in assessing environmental stress on biological communities. Species diversity at the Palo Alto site, as estimated by a time series of number of species, was at a minimum of two in 1998, and after qualitatively trended upward from 1998 through 2007. Diversity has rebounded since the low in 2008 (fig. 19). Total animal abundance has varied significantly during the sampling period (fig. 20). The difficulty with these types of metrics is that they do not consider the possibility that one species can take the place of another or that high abundance is based on one species. Depending on the characteristics of a species new to the community or newly dominant in the community, the community structure and function may change as a result of this change in species composition or dominance. The details of changes in species composition are important because they may reflect the relative ability of species to accommodate environmental stress and redistribute site resources. In general, the species composition at the study site has changed little since 1998, although there have been seasonal eruptions of several species in some years (for example, see figure 22, which shows the abundance of the bivalve Mya arenaria spiking to a value 5-10 times higher than other periods before returning to more average abundance values).

Three common bivalves (Macoma petalum, Mya arenaria, and Gemma gemma) have not shown any consistent trend between years over the 43-year period from 1974 to 2017 (figs. 21-23). Significant seasonal and inter-annual variability has been displayed in species abundances for all species found at the Palo Alto site. The three common bivalves illustrate this variability well; Gemma gemma has been particularly volatile since 2005 . For example, Gemma gemma abundance dropped to near zero in late fall 2007, took three years to recover to previous average densities, and then continued this abundance through 2017.

Six species have shown patterns in their abundance since the 1970s. The first species, Ampelisca abdita, is a small crustacean that lives above the surface of the mudflat in a tube built from selected sediment particles. A. abdita showed a general decline in abundance (fig. 24) after 1998 and mostly low abundances persisted through 2014. In 2015-2016, A abdita showed an increase in abundance. The second species to show an abundance pattern is the small polychaete worm Streblospio benedicti, which also builds a tube above the surface of the mudflat. $S$. benedicti abundance has declined through the study years and, over the past 7 years, the species has maintained a seasonal pattern of increasing spring abundance followed by a fall/winter decline throughout the study (fig. 25). The abundance of the small burrowing crustacean Grandiderella japonica, a deposit feeder, became more seasonally consistent after 2000 (fig. 26), with particularly low abundances in 2006, 2007, and 2011. This species has shown a consistent seasonal peak in abundance in the fall since 1999 with the exception of 2011. Alitta succinea, a burrowing polychaete that feeds on surface deposits and scavenges for detrital food, showed large seasonal fluctuations in abundance throughout the study (fig. 27) and, like other species, its abundance declined in 2011 and remains in low numbers in 2017. Two species showed an increase in abundance within the time series. The first was the polychaete worm Heteromastus filiformis (fig. 28), a subsurface-deposit-feeding, burrowing species that lives deep in the sediment (usually 5-20 cm below the surface of the mudflat). Abundance increased sharply in 1985 and then partly receded in the late 1980s. Abundance remained higher than in the late 1970s until 2008, when there was a large decline in H. filiformis abundance (fig. 28). H. filiformis abundance increased slightly after 2010. Abundance data from the 1980s indicate that this is a species that increases slowly, possibly because of their egg-laying mode of recruitment. The second species showing an increase was Nippoleucon hinumensis, a small, burrowing, surface-deposit-feeding crustacean, which appeared in the dataset in 1988 (fig. 29) following its introduction into the bay in 1986 (Cohen and Carlton, 1995). A complete list of the benthic species 
found at the Palo Alto site in the year 2017 is shown in appendix 9. The benthic species name changes (as of 2017) for the species listed in appendix 9 are shown in appendix 10.

A sudden drop in animal abundance was observed in February 2008. Very few animals were found at the site, and the mudflat community was evidently stressed by some event between the January and February sampling. Possible causes of the stress include sedimentation or freshwater inundation. There was a large storm on January 25, 2008, with rainfall rates exceeding $0.5 \mathrm{~cm} / \mathrm{hr}$ for more than half the day, spanning the low-tide period. No obvious changes in the sediment surface were observed, but sediment changes can occur and be incorporated quickly in this tidal environment. Other possible causes of benthic community death or exodus include a toxic event or anoxia. It is unlikely that either of these occurred, because $M$. petalum were present in the deep sediment in February 2008, and animals were found again at the site in March 2008. The rapid growth required for M. petalum to be found after a dieoff would not happen so quickly. The timeline for recovery from anoxia can be estimated on the basis of observations following an anoxic event at this site in 1975. Macroalgae were deposited on the mudflat surface and began to decay, and the resulting bacterial consumption of oxygen led to anoxia over more than 30 days. The benthic community took many months to recover from this anoxic event. Animals that returned after the disturbance in 2008 include those species with pelagic larvae and mobile adults, as would be expected. Nonmobile brooders returned to the site in 2009 , concurrent with an increase in abundance of the brooding clam $G$. gemma and the brooding polychaete $S$. benedicti. This trend continued into 2017, when brooder species were more than half of the top 10 most abundant species, while oviparous and spawner species made up the rest (fig. 30).

Multivariate analyses of population data of the dominant species with environmental parameters did not reveal any relations, except with the concentration of silver and copper in the sediment and in the tissue of $M$. petalum (using data reported by David and others [2002]). Therefore, this update will primarily focus on those metals. Metal concentration and abundance of species with the most susceptible mode of feeding and reproduction will be compared over the period of the study. One such susceptible species, the worm $H$. filiformis, increased in abundance with the decrease in silver and copper until 2008 (fig. 28). This was of interest because H. filiformis has continual tissue contact with the sediment at the exterior of its body, as well as within its body, as a result of its lifestyle of burrowing through the sediment and consuming a diet of mud and organic particles. In addition, this is one of the few oviparous species in the present community that reproduces exclusively by laying its eggs in the sediment. The larvae hatch after 2 or 3 days and spend a very short planktonic period (2-3 days) before settling back to the mud as juvenile worms (Rasmussen, 1956). The short period limits the species' speed of expansion into new areas. The authors hypothesize that once a few individuals successfully arrived at the study site, $H$. filiformis increased in abundance because either the adult worms or the eggs then found the environment agreeable. This species is not likely to move into an area quickly after an environmental stressor because of its mode of reproduction and short planktonic larval period. A large spike in H. filiformis abundance was observed in January 2008 because of the settling of larvae, but these larvae did not survive the event that occurred before the February sampling. So far, the species has not returned in high numbers to the study site. The dynamics of recovery for this species will continue to be monitored closely given the variability in abundance of $H$. filiformis over monthly to decadal time scales.

Two species that have shown the opposite trend of $H$. filiformis, the crustacean $A$. abdita (fig. 24) and the worm $S$. benedicti (fig. 25) have declined in abundance coincident with the decline in metals. These species have very similar life-history characteristics that make them less susceptible to high silver and copper concentrations in sediment. Both species live on the surface of the sediment in tubes that are built from sediment particles. They feed on particles in the water column or on particles 
that have settled to the sediment surface, brood their young, and produce young that are capable of either swimming or settling upon hatching. These opportunistic characteristics make these species ideal for invading a disturbed or stressed environment; thus, they are capable of rapid increase in population size and distribution. It is not surprising that both species immediately responded to the near-empty community in February 2008 and have subsequently declined (figs. 24 and 25). This abundance pattern is consistent with what is expected of an opportunistic species, confirming both their tolerance to elevated metals as well as an inability to out-compete less opportunistic taxa in diverse communities under non-stressed conditions.

Other species share the characteristics highlighted in our discussion of H. filiformis, S. benedicti, and $A$. abdita; the species with similar characteristics have been combined into plots that examine the percent of abundance represented by each feeding and reproductive mode (figs. 30-33). Because the natural spatial variability (that is, the large standard deviations around the monthly means) and seasonal variability of invertebrate abundance can be quite large, the average percentages for the month of August of each characteristic reproductive and feeding mode are shown in figures 30-33. To interpret these plots, the life-history characteristics must first be examined to determine if there is some mechanism by which this organism could be responding to a decrease in silver or copper in the environment. It is likely that silver, and probably not copper, adversely affected reproduction of all animals (Hornberger and others, 2000). If species with pelagic larvae were transported into the area they did not survive to dominate the community. Species having oviparous and mixed (species capable of oviparity and brooding) reproductive modes (Ahn and others, 1995; Hornberger and others, 2000) are worth examining in more detail. The gradual increase in abundance of these oviparous and mixed reproduction species through 1983 occurred concurrently with the gradual reduction of metals in the environment during that time. In the present environment, with much lower metal concentrations, these species respond to a different variety of stresses, and the percentage of brooding and oviparous individuals in the community reflects those stresses (figs. 30, 31). Although the percentage is volatile, the percentage of brooders plus oviparous individuals has never been as high as it was in the early 1970s. The authors interpret this as being a reflection of the general health of the benthic environment. In a similar manner, we can examine the feeding modes of the majority of the individuals (figs. 32, 33). High concentrations of either copper or silver in the sediment are unlikely to be healthy for species that ingest the sediment in order to consume the interstitial and attached carbon. Thus, it is reasonable to expect species that consume particles from the water column to be more protected from sediment-bound contaminants. Filter feeding species are usually the dominant group throughout the dataset, and the subsurface deposit feeders are the group that shows the largest increase in dominance after the 1970s when improved wastewater treatment at PARWQCP decreased silver and copper in proximal sediments. The multi-decadal trends presented above for abundances of major-species are consistent with the conceptual model posed here.

The change in function of the benthic community over time can be examined by ranking the top 10 species by abundance and plotting the $\log (n+1)$ of mean abundance against the rank of each species (Whittaker, 1965). The plot for 2017 (fig. 34) is indicative of a healthy benthic community with species dominance, as revealed by abundance, not showing large differences among the top 10 species. An examination of similar plots for August of three hydrologically dry years during this study (1977, 1989, and 2002) shows that the shape of the curve has varied and that the 2017 curve is similar to that seen in 1989. The series of curves shows a community that was, with the rest of the species having similar abundancies, heavily dominated by three species in 1977, 1989, and 2017, versus a community with one dominant species in 2002. Although G. gemma is the most dominant species in all years except 1989; in 2017, the graph shows a smooth downward slope showing a more homogenized decrease in species 
abundance. The 1977 community plot is the most extreme, with three species dominating the community and the remainder having similar but relatively low abundances. It is informative to examine the rank-abundance plots within the context of the life-history characteristics of each species to determine if shifts in plot shape coincide with a shift in community structure and function that might be indicative of a healthier environment. Two critical life history characteristics are shown: feeding mode (fig. 35) and reproductive mode (fig. 36). The 1977 community was dominated by filter feeding species (species that consume particles in the water column), species that have the option of either filter feeding or feeding on the sediment surface (mixed feeders), and two species that feed on food particles on the sediment surface. In 1989, the species composition had shifted, relative to 1977, such that filter feeding species, subsurface deposit and surface deposit feeding species (those that ingest sediment and strip the food off of the sediment in their gut) dominated the community. In 2002, a shift was observed towards species that could either filter feed or deposit feed (mixed feeders) and those species that feed on subsurface sediment. The most recent data (2017) show the community to be similar to that of 1989, with the composition still having greater abundance of subsurface and surface deposit feeders, relative to 1977 . The species that returned following the defaunation event in January/February 2008 have maintained this pattern. Thus, it is unlikely that any of the sediment-borne contaminants considered in this study caused the collapse of the community in early 2008.

An examination of these rank-abundance plots using reproductive mode as the descriptor for each point is equally informative (fig. 36). The dominant species in 1977 were species that brood their young and release fully functional juveniles into the environment. In 1989, there were still several brooders, but there were also two species that lay their eggs in the sediment. It would appear that brooding species have a reproductive advantage over other modes, as they occupied the top-ranking position since 1977 (fig. 36). It is possible that some of the metal contaminants found in the sediment in the 1970s at this location limited the success of species that consumed the sediment for food, laid eggs in the sediment, or depended on water-borne larvae to repopulate the community. Species that spawn their gametes into the water column in combination with those that lay eggs in the sediment (oviparous) have sometimes ranked highly in terms of their presence. Interestingly, the reproductive mode of most species present in 2017 is brooding with some egg laying (oviparous) and spawning species.

\section{Summary}

\section{Long-Term Observations}

Since 1974, USGS personnel have monitored and conducted basic research on the benthic sediments and biological community in the vicinity of the discharge of the Palo Alto Regional Water Quality Control Plant (PARWQCP). The time series presented here updates and extends previous findings (for example, Luoma and others, 1991, 1995a, 1996; Hornberger and others, 2000; Thompson and others, 2002; Shouse and others, 2003, 2004; Moon and others, 2005; Cain and others, 2006; Dyke and others, 2012, 2014) with additional data from January 2017 through December 2017 to create a record spanning more than 40 years. This long-term dataset includes sediment chemistry and tissue concentrations of metals (1977-2017 for copper and silver, 1994-2017 for other metals), condition index (1988-2017), and reproductive activity in M. petalum and population dynamics of benthic invertebrate species (1974-2017). The time series encompasses the period when exceptionally high concentrations of copper and silver were found in M. petalum (1970s and early 1980s) and the subsequent period when those concentrations declined. The sustained record of biogeochemical data at this site provides a rare opportunity to examine the biological response to metal contamination within this ecosystem over multiple time scales. 
Studies during the 1970s showed that sediments and M. petalum at the Palo Alto site contained highly elevated levels of metals, especially silver and copper, as a result of metal-containing effluent being discharged from the Palo Alto Regional Water Quality Control Plant (PARWQCP) to south San Francisco Bay. In the early 1980s, the point-source metal loading from the nearby PARWQCP was significantly reduced as a result of advanced treatment of influent and source mitigation. Coincident with declines in metal loadings, concentrations of metals in the sediment and in the clam M. petalum (serving as a biomonitor of metal exposures) also declined, as previously described by Hornberger and others (2000). Inter-annual trends in clams and sediments were highly correlated with copper loadings from PARWQCP (concurrent loading data for silver were not available). Metal levels in sediments and clams responded relatively quickly to changes in metal loading; the reduction in metal loadings by the PARWQCP resulted in a reduction in metal concentrations in both the sediment and M. petalum within a year (Hornberger and others, 2000).

Biological responses to metal inputs to south San Francisco Bay were assessed at different levels of organization. These responses are interpreted within the appropriate temporal context. Because metal exposures were already high when the study began, interpretations are based on observed changes in biological attributes as metal inputs declined. In general, discernable responses at the organism level (that is, reproductive activity, a manifestation of a cellular or physiological change) to metal exposure may occur within a relatively short time (for example, at intra- and inter-annual time scales as previously exposed individuals recover and successive cohorts become established), whereas population- and community-level responses take longer to develop. Stable changes in the benthic community may take a relatively long period of time to be expressed because of the normally high degree of intra-annual variability of benthic community dynamics, which reflects the cumulative response to natural and anthropogenic disturbances. It is therefore critical that sampling frequency and duration be conducted at temporal scales appropriate to characterize the different biological responses.

During the first 10 years of this study, when the metal concentrations were initially high and declining, the benthic community was largely dominated by nonindigenous, opportunistic species. This dominance was initially attributed to their ability to survive the many physical disturbances on the mudflat (Nichols and Thompson, 1985a, b). These disturbances included sediment erosion and deposition and aerial exposure at extreme low tides, as well as less well-defined stresses. The possible effects of metal exposure as a disturbance factor were not considered in the analyses by Nichols and Thompson because the decline in metal concentrations in M. petalum and sediment had just begun.

However, data collected throughout the period of declining metal exposure have revealed biological responses to this metal decline. Reproductive activity improved within a year or two of reduced metal exposure (Hornberger and others, 2000), and responses at the population and community levels were observed afterward. Identification of these responses was possible because the frequency of sampling allowed long-term trends related to metal contamination to be identified within the context of repeating seasonal cycles and unrelated intra-annual variation.

The ecology of the Palo Alto mudflats is part of the larger south San Francisco Bay, which has been undergoing some changes in recent years. During 1999-2005, USGS scientists noticed an increase in phytoplankton biomass in the southern bay. Sampling in the deeper water of the southern bay showed that the bivalves were mostly absent from the system during this increase in primary production. Cloern and others (2007) indicate that the cause of the decline in bivalves was an increase in fish predators resulting from increased offshore upwelling activity. The higher reproductive success of demersal fish, crabs, and shrimp during this period resulted in a higher number of juveniles moving into the south San Francisco Bay to grow. Since 2005, scientists have seen the large bivalve populations fluctuate more than in previous decades, and these fluctuations have been reflected in changes in phytoplankton 
biomass in the system (primarily through an increase in phytoplankton biomass in late summer and fall). The value of these findings in greater south San Francisco Bay to this study is twofold. First, it reinforces the importance of the benthic community's impact on ecosystem function and solute cycling. Second, it shows that the high intertidal community at the Palo Alto site has not been demonstrably affected by these greater south San Francisco Bay influences during these years. These findings reinforce the authors' confidence that the changes observed in the benthic community are in large part due to local factors.

\section{Observations}

Throughout 2017, copper and silver concentrations in sediments remained representative of the concentrations observed since 1990, following the significant reductions in concentrations during the 1980s that coincided with reductions in the discharge of these elements from PARWQCP. Since 1990, annual mean copper and silver concentrations have fluctuated modestly. Copper concentrations have gradually declined over that period, while silver concentrations have not. Like silver, sedimentary concentrations of other elements have varied from year to year but shown no sustained temporal trend.

The most recent results (2017) showed an increase in all metals in M. petalum. The increase in copper was particularly notable given that it approached concentrations (on an annual basis) that had not been observed since the late 1980s. Mercury concentrations in 2017 were the highest on record. The increased levels of metals were coupled with a relatively low condition index, which is indicative of the physiological state of the clam. An analysis of factors influencing the physiological condition of $M$. petalum is beyond the scope of this study. However, since the 1990s, metal exposure would seem an unlikely causative agent given the low and relatively stable concentrations of metals in the sediments. Furthermore, inter-annual variation in copper and silver in M. petalum from 1991 to 2006 did not correlate with discharge of copper and silver from PARWQCP (Lorenzi and others, 2007), indicating that, as with other elements of regulatory interest, including chromium, nickel, and zinc, regional-scale factors now largely influence sedimentary and bioavailable concentrations (see, for example, Luoma and others, 1998). In addition to the biotic factors discussed in previous sections, abiotic factors that affect the seasonal and year-to-year patterns in sedimentary and tissue concentrations may include precipitation, nonpoint-source runoff, cycling of legacy contamination within the bay, accelerated erosion of salt marsh banks in recent years, and periods of accretion and erosion of sediment on the mudflat.

The long-term dataset that we augment with this report demonstrates various adverse effects of contaminants on benthic organisms. Decreasing particulate concentrations of trace metals in the local environment have benefited resident populations of invertebrates, as evidenced by increased reproductive activity in $M$. petalum that has been sustained through 2017 . In early 2008 , the benthic community declined, with few animals present in February. This decline was likely the result of a natural stressor, such as a sedimentation or freshwater event, and the composition of the benthic community supports that supposition. Mobile animals such as M. petalum that were capable of burrowing down to avoid the stressor probably did so, but many other species either relocated or did not survive at the study site. This natural disturbance gives scientists the opportunity to observe mudflat community recovery from a natural stressor and to compare this recovery to that observed during the long-term decline of metals in sediment and M. petalum. Shifts in species abundance at the study site have been interpreted to be a response to decreasing sediment contaminants within two years of improved wastewater treatment at PARWQCP. These community changes have included a shift from species that live on the surface, filter food out of the water column or consume particles on the sediment surface, and brood their young; to a community dominated by species that live on and below the 
surface, consume the sediment directly to harvest food particles, and spawn and lay eggs in the sediment. Hence, the benthic community now has a greater dependence on sediment for food and reproduction relative to the late 1970s, consistent with management practices that have improved sediment quality. The 2008-2017 data reveal a community that had a short-term physical stressor but not one that was subject to trace-metal contamination. In 2017, the species abundance data continues to show signs of a community that has recovered and stabilized, and the constancy of functional groups reflects the stability of the ecosystem. Thus, the data from the recent record (that is, within the past three decades) reflect the improved ecological condition of the Palo Alto site which appears indicative of an integrated regional ecological baseline. This "natural experiment" has given USGS scientists an opportunity to test various hypotheses on the benthic community response to different stressors. Future data will further refine the understanding of the response of this benthic community to natural and anthropogenic stressors.

\section{Value of Long-Term Monitoring}

This study highlights the importance of long-term ecosystem monitoring. Although monitoring studies cannot always unambiguously determine the causes of variation in metal concentrations or benthic community structure, time-series data may reveal ecological responses that are distinctively associated with human activities. Changes and trends in community structure that may be related to anthropogenic stressors, as was seen in this study for multiple trace metals, can be established only with a concerted and committed sampling effort of sufficient duration and frequency and data interpretation. The strength and uniqueness of this study is the integrated analysis of metal exposure and biological response at intra- and inter-annual time scales over multiple decades.

Human activities continue to impact San Francisco Bay and its watershed. Factors that may influence metals in the near and long term include climate variation, nonpoint-source runoff and efforts to mitigate it, reconnection of reclaimed intertidal areas to the bay, cycling of legacy contamination within the bay, new and redevelopment of the Bay Area landscape, and sea-level rise. Among emerging contaminants of concern are nanomaterials, many of which include metal-based products in forms for which environmental scientists and regulators have little or no experience. Only recently have quantitative descriptions become available of the bioavailability of trace metals from such sources (Croteau and others, 2011, 2014). The long-term, detailed, integrated ecological baseline that has been established at this sampling site will be uniquely valuable in assessing the response of the environment and informing management and regulatory agencies as human activities within the watershed continue.

\section{Acknowledgment}

Le Kieu and Mark Marvin-DiPasquale, U.S. Geological Survey, provided the mercury data.

\section{References Cited}

Ahn, I.Y., Kang, Y.C, and Choi, J.W., 1995, The influence of industrial effluents on the intertidal benthic communities in Panweol, Kyeonggi Bay (Yellow Sea) on the west coast of Korea: Marine Pollution Bulletin, v. 30, p. 200-206.

Alpine, A.E., and Cloern, J.E., 1992, Trophic interactions and direct physical effects control phytoplankton biomass and production in an estuary: Limnology and Oceanography, v. 37, p. 946955. 
Cain, D.J., and Luoma, S.N., 1990, Influence of seasonal growth, age and environmental exposure on $\mathrm{Cu}$ and $\mathrm{Ag}$ in a bivalve indicator, Macoma balthica in San Francisco Bay: Marine Ecology Progress Series 60, p. 45-55.

Cain, D.J., Parchaso, F., Thompson, J.K., Luoma, S.N., Lorenzi, A.H., Moon, E., Shouse, M.K., Hornberger, M.I., and Dyke, J.L., 2006, Near-field receiving water monitoring of trace metals and a benthic community near the Palo Alto Regional Water Quality Control Plant in south San Francisco Bay, California; 2005: U.S. Geological Survey Open-File Report 2006-1152, 128 p.

Cain, D.J., Thompson, J.K., Parchaso, F., Pearson, S., Stewart, R., Turner, M., Barasch, D., and Luoma, S.N., 2017, Near-field receiving water monitoring of trace metals and a benthic community near the Palo Alto Regional Water Quality Control Plant in south San Francisco Bay, California; 2016: U.S. Geological Survey Open-File Report 2017-1135, 75 p., https://doi.org/10.3133/ofr20171135.

Childress, C.J.O., Foreman, W.T., Connor, B.F., and Maloney, T.J., 1999, New reporting procedures based on long-term method detection levels and some considerations for interpretations of waterquality data: U.S. Geological Survey Open-File Report 99-193, 19 p.

Cloern, J.E., Jassby, A.D., Thompson, J.K., and Hieb, K., 2007, A cold phase of the east Pacific triggers new phytoplankton blooms in San Francisco Bay: Proceedings National Academy of Science, v. 104, no. 47, p. 18561-18565.

Cohen, A.N., and Carlton, J.T., 1995, Biological study, nonindigenous aquatic species in a United States estuary; a case study of the biological invasions of the San Francisco Bay and Delta: Washington, D.C., Report for the U.S. Fish and Wildlife Service and the National Sea Grant College Program, Connecticut Sea Grant, http://nsgl.gso.uri.edu/conn/connt95002/connt95002index.html.

Croteau, M.-N., Misra, S.K., Luoma, S.N., and Valsami-Jones, E., 2011, Silver bioaccumulation dynamics in a freshwater invertebrate after aqueous and dietary exposure to nanosized and ionic Ag: Environmental Science and Technology, v. 45, p. 6660-6607.

Croteau, M.-N., Misra, S.K., Luoma, S.N., and Valsami-Jones, E., 2014, Bioaccumulation and toxicity of $\mathrm{CuO}$ nanoparticles by a freshwater invertebrate after waterborne and dietborne exposures:

Environmental Science and Technology, v. 48, p. 10929-10937.

David, C.P.C., Luoma, S.N., Brown, C., Cain, D.J., Hornberger, M., and Lavigne, I.R., 2002, Near-field receiving water monitoring of trace metals in clams (Macoma balthica) and sediments near the Palo Alto Water Quality Control Plant in south San Francisco Bay, California; 1999-2001: U. S. Geological Survey Open-File Report 02-453, 105 p.

Dyke, J.L., Parchaso, F., Thompson, J.K., Cain, D.J., Luoma, S.N., and Hornberger, M.I., 2012, Nearfield receiving water monitoring of trace metals and a benthic community near the Palo Alto Regional Water Quality Control Plant in south San Francisco Bay, California; 2011: U.S. Geological Survey Open-File Report 2012-1165, 108 p.

Dyke, J.L., Cain, D.J., Thompson, J.K., Kleckner, A.E., Parchaso, F., Hornberger, M.I., and Luoma, S.N., 2014, Near-field receiving water monitoring of trace metals and a benthic community near the Palo Alto Regional Water Quality Control Plant in south San Francisco Bay, California; 2013: U.S. Geological Survey Open-File Report 2014-1174, 81 p., http://dx.doi.org/10.3133/ofr20141174.

Elrick, K.A., and Horowitz, A.J., 1985, Analysis of rocks and sediments for arsenic, antimony, and selenium, by wet digestion and hydride generation atomic absorption: U.S. Geological Survey OpenFile Report 85-497, 14 p.

Förstner, U., and Wittmann, G.T.W., 1979, Metal pollution in the aquatic environment: SpringerVerlag, Berlin, Germany.

Glaser, J.A., Foerst, D.L., Mckee, G.D., Quave, S.A., and Budde, W.L., 1981, Trace analyses for wastewaters: Environmental Science and Technology, v. 15, no. 12, p. 1426-1435. 
Hornberger, M., Luoma, S., Cain, D., Parchaso, F., Brown, C., Bouse, R., Wellise, C., and Thompson, J., 2000, Linkage of bioaccumulation and biological effects to changes in pollutant loads in south San Francisco Bay: Environmental Science and Technology, v. 34, p. 2401-2409.

Hornberger, M.I., Luoma, S.N., Van Geen, A., Fuller, C.C., and Anima, R., 1999, Historical trends of metals in the sediments of San Francisco Bay, California: Marine Chemistry, v. 64, p. 39-55.

Kennish, J.K., 1998, Pollution impacts on marine biotic communities: New York, CRC Press, 310 p.

Liber, K., 2011, Cold digestion of invertebrates for the Selenium Project. Method developed by C.W. and E.F. 2007. Revised Mar 2011 MK: Water Quality Laboratory, Toxicology Center, University of Saskatchewan.

Long, E.R., MacDonald, D.D., Smith, S.L., and Calder, F.D., 1995, Incidence of adverse biological effects within ranges of chemical concentrations in marine and estuarine sediments: Environmental Management, v. 19, p. 81-97.

Lorenzi, A., Cain, D.J., Parchaso, F., Thompson, J.K., Luoma, S.N., Hornberger, M.I., Dyke, J.L., Cervantes, R., and Shouse, M.K., 2007, Near-field receiving water monitoring of trace metals and a benthic community near the Palo Alto Regional Water Quality Control Plant in south San Francisco Bay, California; 2006: U.S. Geological Survey Open-File Report 2007-1199, 121 p.

Luoma, S.N., Cain, D.J., and Johansson, C., 1985, Temporal fluctuations of silver, copper and zinc in the bivalve Macoma balthica at five stations in south San Francisco Bay: Hydrobiologia, v. 129, p. 109-120.

Luoma, S.N., Cain, D.J., Brown, C., and Axtmann, E.V., 1991, Trace metals in clams (Macoma balthica) and sediments at the Palo Alto mudflat in south San Francisco Bay; April, 1990-April, 1991: U.S. Geological Survey Open-File Report 91-460, 47 p.

Luoma, S.N., Cain, D.J., Brown, C., and Hornberger, M., 1995a, Near-field receiving water monitoring of trace metals in clams (Macoma balthica) and sediments near the Palo Alto and San Jose/Sunnyvale Water Quality Control Plants in south San Francisco Bay; June 1993-October 1994: U.S. Geological Survey Open-File Report 95-299, 83 p.

Luoma, S.N., Cain, D.J., Brown, C., Hornberger, M., and Bouse, R., 1996, Near-field receiving water monitoring of trace metals in clams (Macoma balthica) and sediments near the Palo Alto and San Jose/Sunnyvale Water Quality Control Plants in south San Francisco Bay; December 1994-December 1995: U.S. Geological Survey Open-File Report 96-203, 90 p.

Luoma, S.N., and Cloern, J.E., 1982, The impact of wastewater discharge on biological communities in San Francisco Bay, in Conomos, T.J., ed., San Francisco Bay-The urbanized estuary: American Association for the Advancement of Science, San Francisco, Calif., p. 137-160.

Luoma, S.N., Ho, Y.B., and. Bryan, G.W., 1995b, Fate, bioavailability and toxicity of silver in estuarine environments: Marine Pollution Bulletin, v. 31, p. 44-54.

Luoma, S.N., Wellise, C., Cain, D.J., Brown, C., Hornberger, M., and Bouse, R., 1998, Near-field receiving water monitoring of trace metals in clams (Macoma balthica) and sediments near the Palo Alto and San Jose/Sunnyvale Water Quality Control Plants in south San Francisco Bay; 1997: U.S. Geological Survey Open-File Report 98-563, 88 p.

Moon, E., Shouse, M.K., Parchaso, F., Thompson, J.K., Luoma, S.N., Cain, D.J., and Hornberger, M.I., 2005, Near-field receiving water monitoring of trace metals and a benthic community near the Palo Alto Regional Water Quality Control Plant in south San Francisco Bay, California; 2004: U.S. Geological Survey Open-File Report 2005-1279, 118 p.

Morrisey, D.J., Underwood, A.J., and Howitt, L., 1996, Effects of copper on the faunas of marine softsediments; an experimental field study: Marine Biology, v. 125, p. 199-213.

Newman, M.C., 1998, Fundamentals of ecotoxicology, Sleeping Bear Press, Chelsea, Mich., 402 p. 
Nichols, F.N., and Thompson, J.K., 1985a, Persistence of an introduced mudflat community in south

San Francisco Bay, California: Marine Ecology Progress Series, v. 24, p. 83-97.

Nichols, F.N., and Thompson, J.K., 1985b, Time scales of change in the San Francisco Bay benthos: Hydrobiologia, v. 129, p. 121-138.

Parchaso, F., 1993, Seasonal reproduction of Potamocorbula amurensis in San Francisco Bay, California: San Francisco, Calif., San Francisco State University, M.S. thesis, 79 p.

Phillips, D.J.H., and Rainbow, P.S., 1993, Biomonitoring of trace aquatic contaminants: Barking, England, Elsevier Science Publishers, LTD, 371 p.

Rasmussen, E., 1956, The reproduction and larval development of some polychaetes from the Isefjord, with some faunistic notes: Biologiske Meddelelser, det Kongelige Danske Videnskabernes Selskab, v. 23, no. 1, p. 1-84.

Rygg, B., 1985, Effect of sediment copper on benthic fauna: Marine Ecology Progress Series, v. 25, p. 83-89.

San Francisco Estuary Institute, 1997, RMP, regional monitoring program for trace substances; 1996 : Richmond, Calif., San Francisco Estuary Institute, 349 p.

Shouse, M.K., 2002, The effects of decreasing trace metal concentrations on benthic community structure: San Francisco, Calif., San Francisco State University, M.S. thesis, 177 p.

Shouse, M.K., Parchaso, F., and Thompson, J.K., 2003, Near-field receiving water monitoring of benthic community near the Palo Alto Water Quality Control Plant in south San Francisco Bay; February 1974 through December 2003: U.S. Geological Survey Open-File Report 2003-224, 39 p.

Shouse, M.K., Parchaso, F., and Thompson, J.K., 2004, Near-field receiving water monitoring of benthic community near the Palo Alto Water Quality Control Plant in south San Francisco Bay; February 1974 through December 2003: U.S. Geological Survey Open-File Report 2004-1210, 39 p. Simon, T.P., 2002, Biological response signatures: Boca Raton, Florida, CRC Press, 608 p.

Suter, G.W., II, 2001, Applicability of indicator monitoring to ecological risk assessment: Ecological Indicators, v. 1, p. 101-112.

Thompson, J.K., and Parchaso, F., 2012, Benthic invertebrate community assessment as a phytoplankton consumer and fish and bird prey source before and after the start of the restoration: South Bay Salt Pond Restoration Project Cooperative Agreement \#2009-0211, 90 p.

Thompson, J.K., Parchaso, F., and Shouse, M.K., 2002, Near-field receiving water monitoring of benthic community near the Palo Alto Water Quality Control Plant in south San Francisco Bay; February 1974 through December 2000: U.S. Geological Survey Open-File Report 02-394, 117 p.

Thomson, E.A., Luoma, S.N., Johansson, C.E., and Cain, D.J., 1984, Comparison of sediments and organisms in identifying sources of biologically available trace metal contamination: Water Research, v. 18, p. 755-765.

Thomson-Becker, E.A., and Luoma, S.N., 1985, Temporal fluctuations in grain size, organic materials and iron concentrations in intertidal surface sediment: Hydrobiologia, v. 129, p. 91-109.

Topping, B.R., and Kuwabara, J.S., 2003, Dissolved nickel and benthic flux in south San Francisco Bay; a potential for natural sources to dominate: Bulletin of Environmental Toxicology and Chemistry, v. 71, p. 46-51.

U.S. Environmental Protection Agency, 2002, Method 1631, Revision E: Mercury in water by oxidation, purge and trap, and cold vapor atomic fluorescence spectrometry: Washington, D.C., U.S. Environmental Protection Agency, EPA-821-R-02-019, 38 p.

U.S. Environmental Protection Agency, 2004, Revised assessment of detection and quantitation approaches: Washington, D.C., U.S. Environmental Protection Agency, EPA-821-B-04-005, 254 p. 
Van Geen, A., and Luoma, S.N., 1999, The impact of human activities on sediments of San Francisco Bay, California: an overview: Marine Chemistry, v. 64, p. 1-6.

Wang, W., and Fisher, N.S., 1999, Delineating metal accumulation pathways for marine invertebrates: Science of the Total Environment, v. 237, p. 459-472.

Weesner, F.M., 1960, General zoological microtechniques: Baltimore, Maryland, The Waverly Press, Inc., $230 \mathrm{p}$.

Whittaker, R.H., 1965, Dominance and diversity in land plant communities-Numerical relations of species express the importance of competition in community function and evolution: Science, v. 147, no. 3655 , p. $250-260$. 


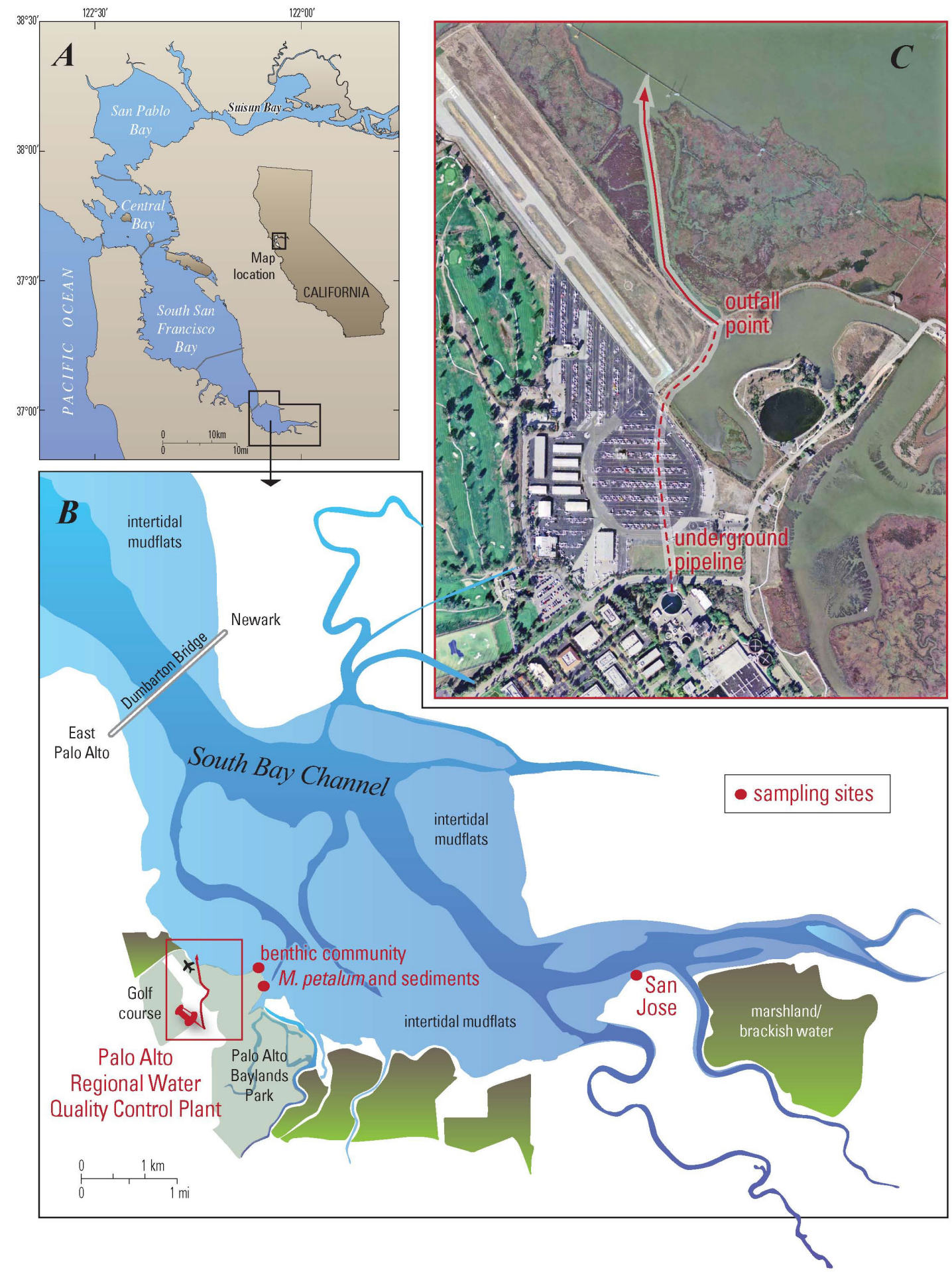

Figure 1. Location of the Palo Alto sampling site in south San Francisco Bay, Calif. $A$, Sampling area within the greater San Francisco Bay region. $B$, The intertidal mudflats are shaded light blue, subtidal in dark blue, and marshland/brackish water in green/brown. The benthic community and $M$. petalum and sediments points make up the Palo Alto sampling site. The San Jose sampling site (inactive) is also shown for reference. $C$, Effluent from the Palo Alto Regional Water Quality Control Plant (red thumbtack in $B$ ) is discharged by way of an underground pipe (dashed red line) until it reaches the mouth of a small channel that connects to the intertidal mudflat approximately 1 kilometer northwest of the sampling sites. 
A.

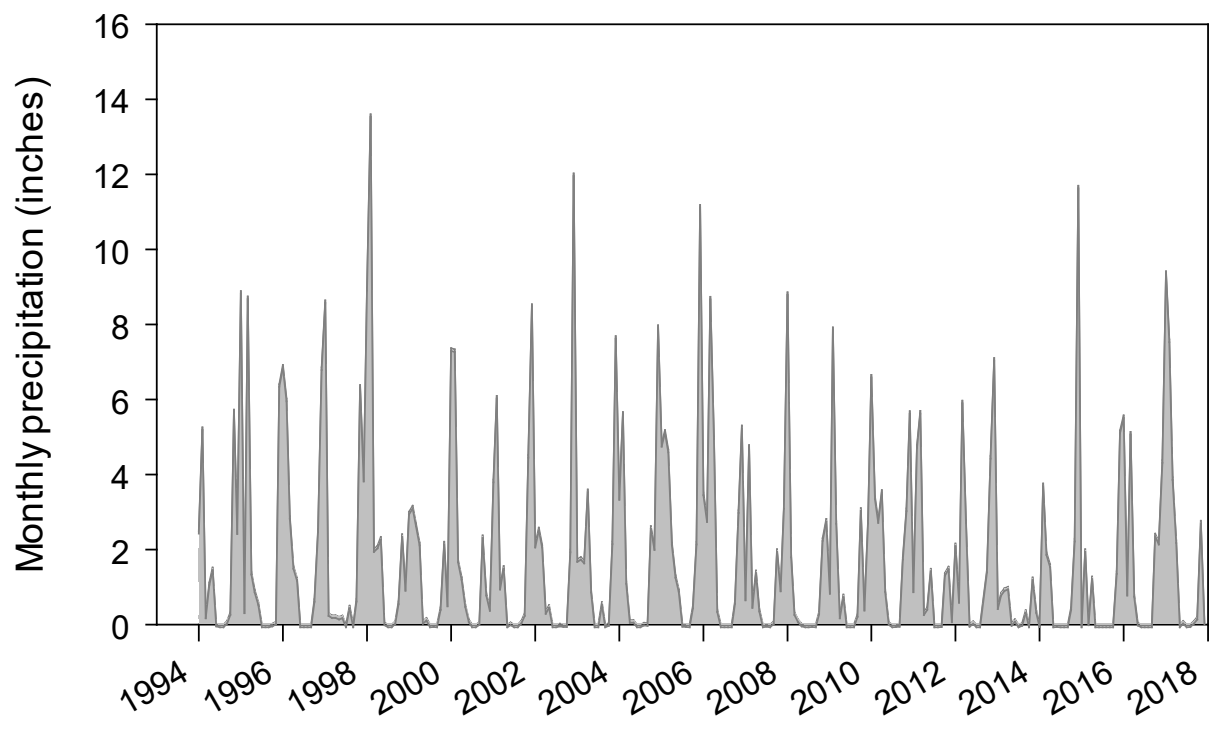

$\mathrm{B} \square$

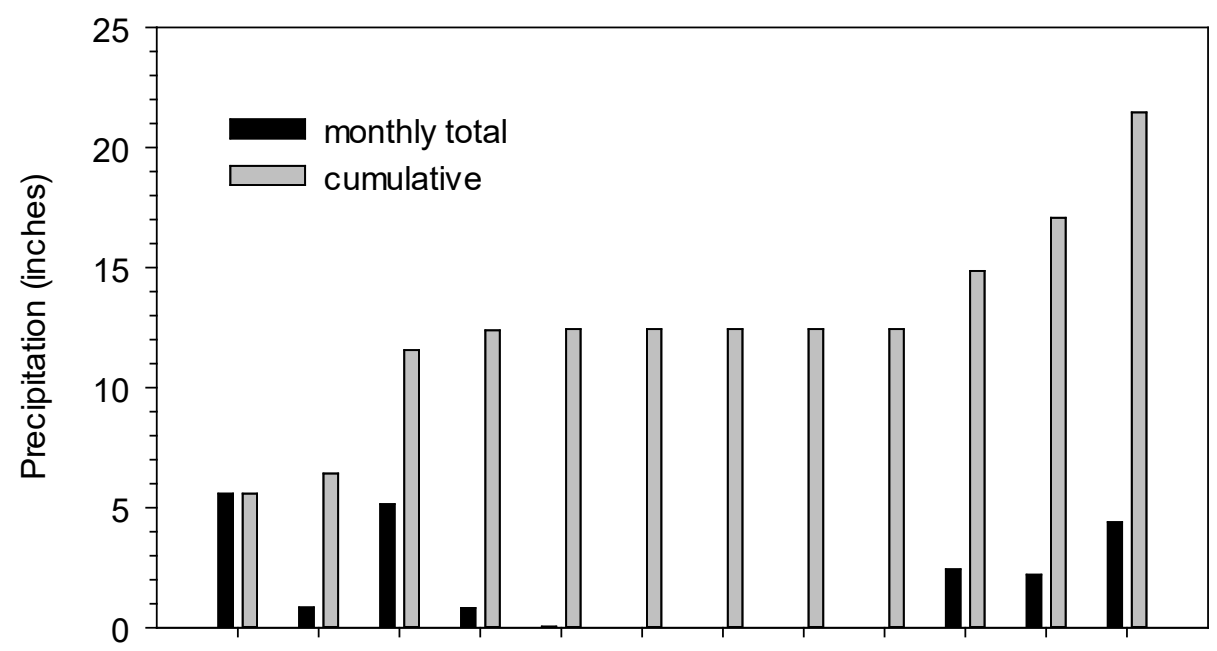

Jan. Feb. Mar. Apr. May June July Aug. Sept. Oct. Nov. Dec.

Figure 2. Precipitation recorded at San Francisco WB AP in San Mateo County, Calif. A, Monthly precipitation for the period 1994-2017. B, Monthly (dark bar) and cumulative (light bar) precipitation for 2017. The station (identification SFF) is operated by the National Weather Service. 
A.

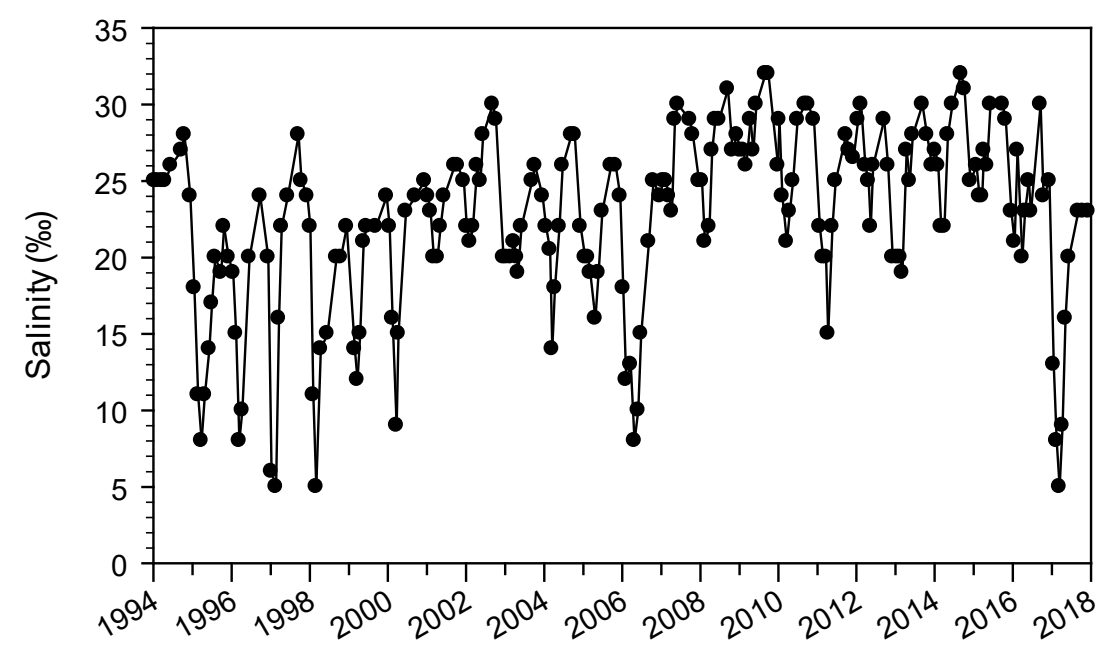

B.

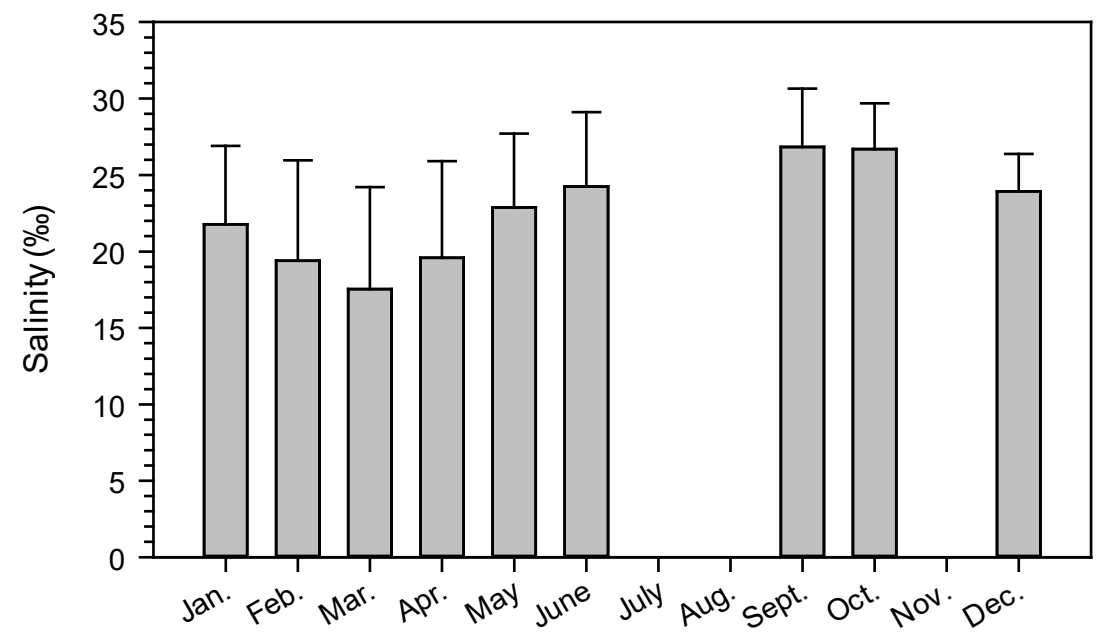

Figure 3. Surface-water salinity in parts per thousand (\%o) at the Palo Alto site, Calif., 1994-2017. A, Monthly data (dots) for the period 1994-2017. $B$, The general seasonal variation as the monthly averages ( $\pm 1 \mathrm{std}, n=23$ ). 


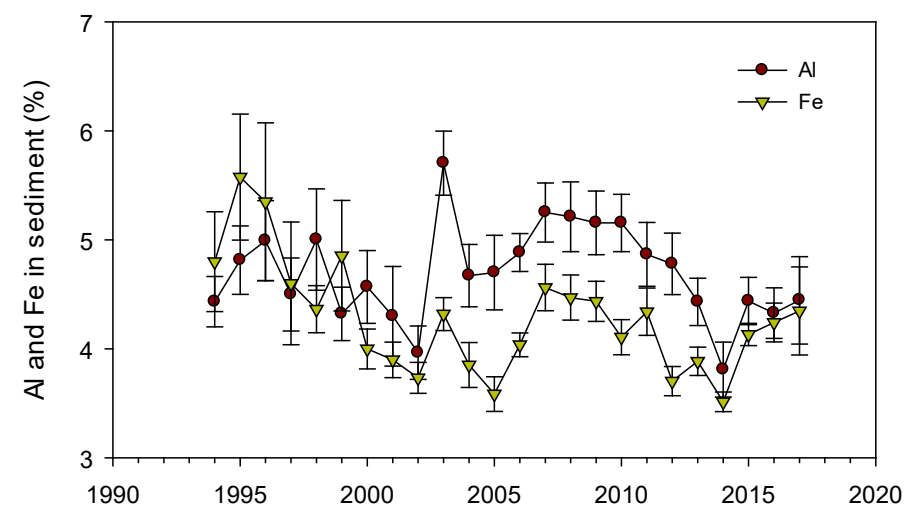

B.

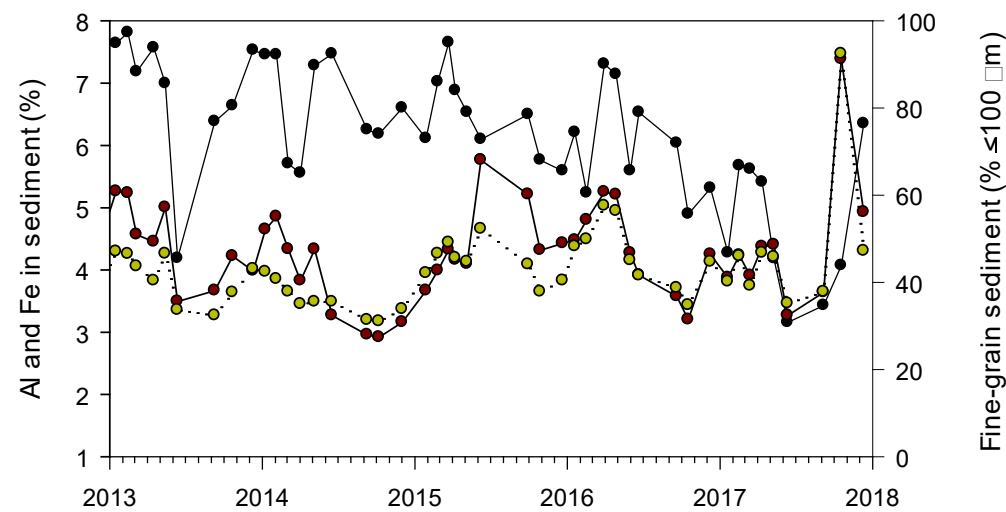

C.

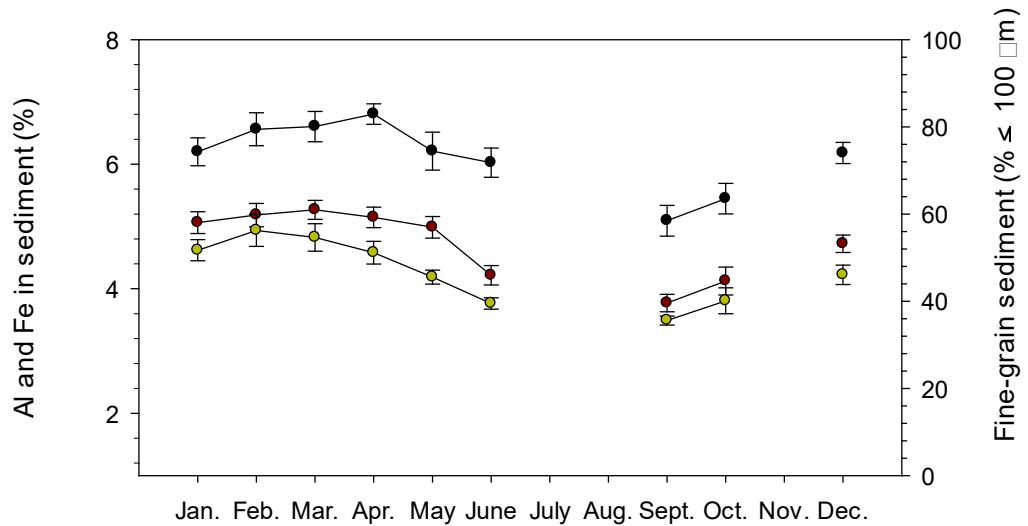

Figure 4. Aluminum (Al), iron (Fe), and silt/clay in sediments, Palo Alto, Calif., 1994-2017. \%, percent, mg/kg, milligrams per kilogram; $\mu \mathrm{m}$, micrometer. $A$, Annual concentration of aluminum and iron (extracted by near-total digest) for the period 1994-2017. Data are reported as percent. Each value is the grand mean for nine samples per year with the standard error of those means (SEM). $B$, Percent aluminum, iron, and fine sediment $(\leq 100 \mu \mathrm{m})$ for the period 2013-2017. Data represent the mean values. C, The monthly mean of all samples collected from 19942017, illustrating the general seasonal variation in aluminum, iron, and percent fine sediments. Collections are not made in July, August, and November. The error bars are the SEM. 
A.

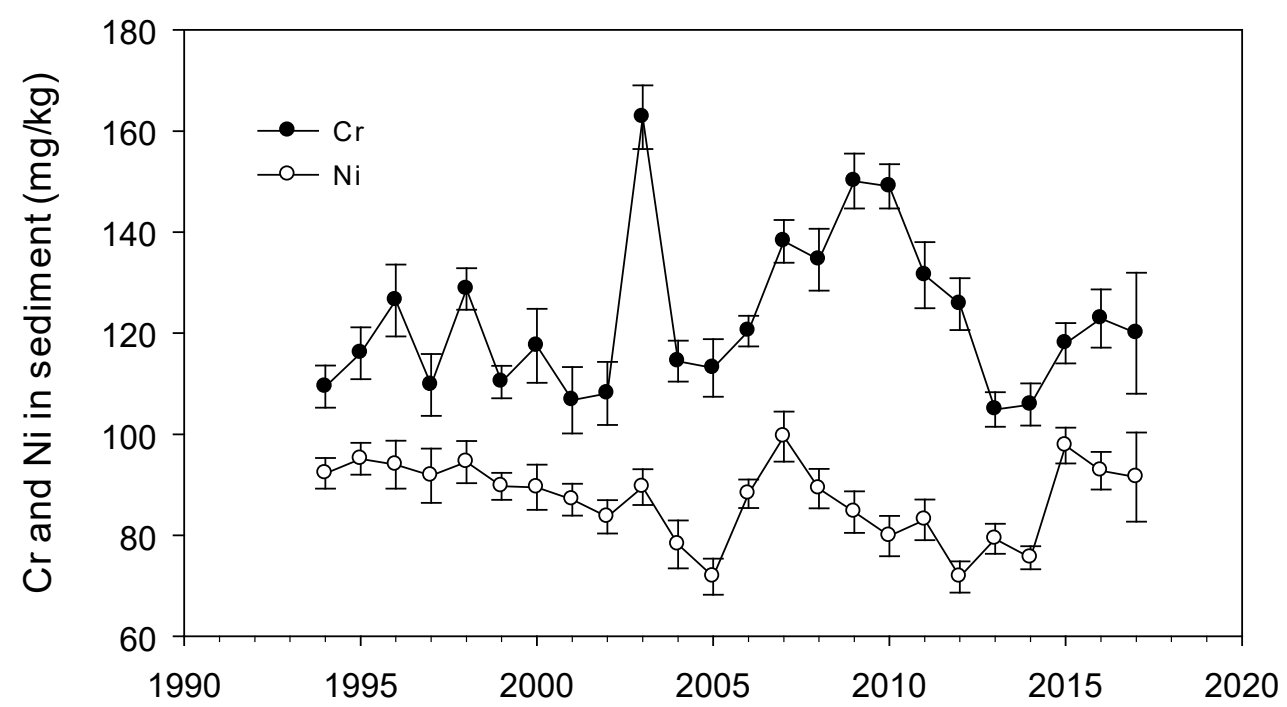

B.

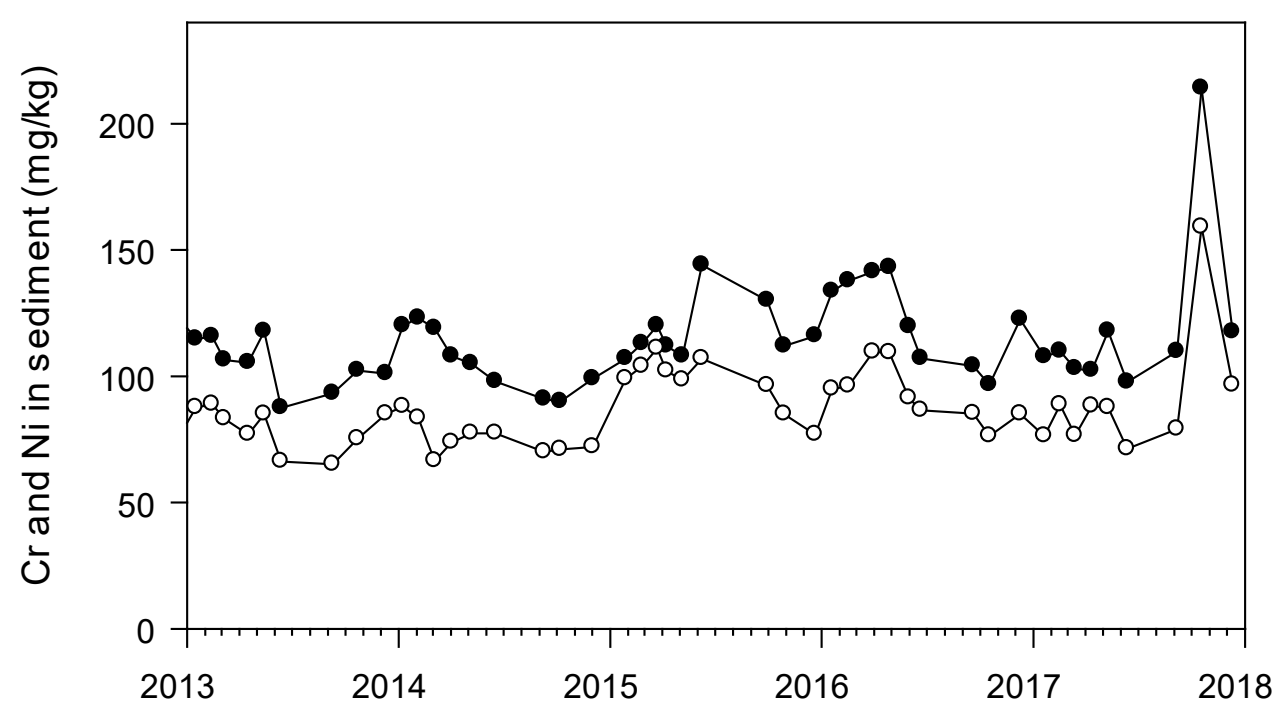

Figure 5. Chromium (Cr) and nickel (Ni) in sediments in milligrams per kilogram (mg/kg), Palo Alto, Calif., 19942017. A, Annual concentration of chromium and nickel for the period 1994-2017. Each value is the grand mean for nine samples per year with the standard error of those means (SEM). B, Data for the period 2013-2017. Data represent the mean value. 
A.

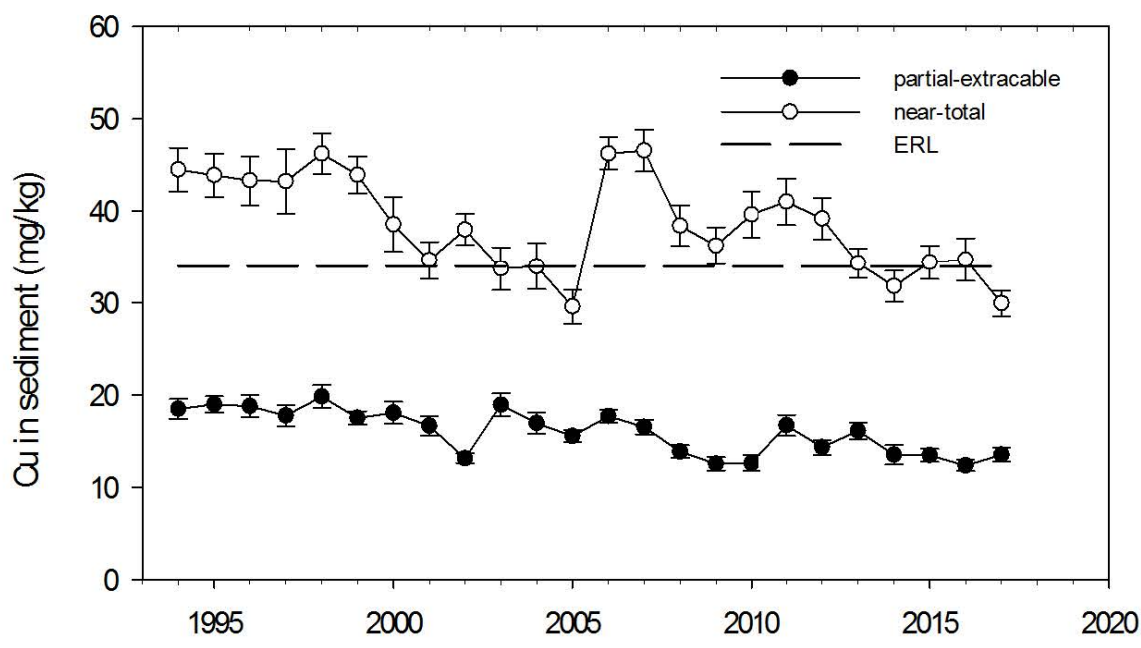

B.

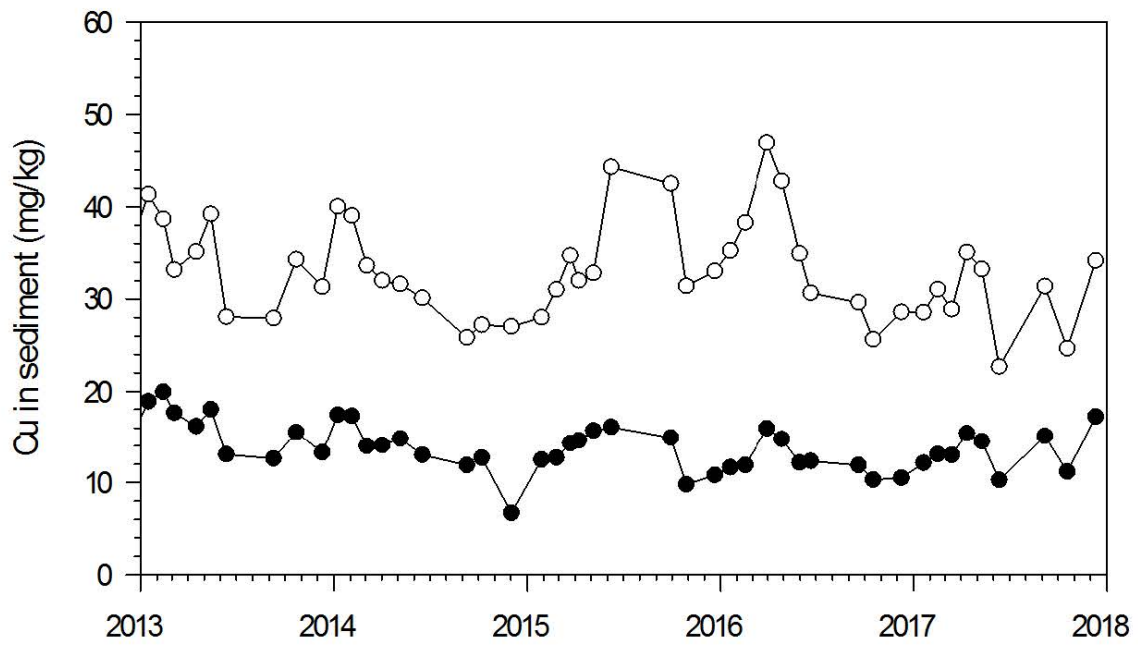

Figure 6. Copper (Cu) in sediments, in milligrams per kilogram (mg/kg), Palo Alto, Calif., 1994-2017. A, Annual concentration of near-total and partial-extractable copper for the period 1994-2017. Each value is the grand mean for nine samples per year with the standard error of those means (SEM). The dashed line is the effects range low (ERL), the concentration below which the expected incidence of adverse effects is low (9 percent). $B$, Data for the period 2013-2017. Data represent the mean value. 
A.

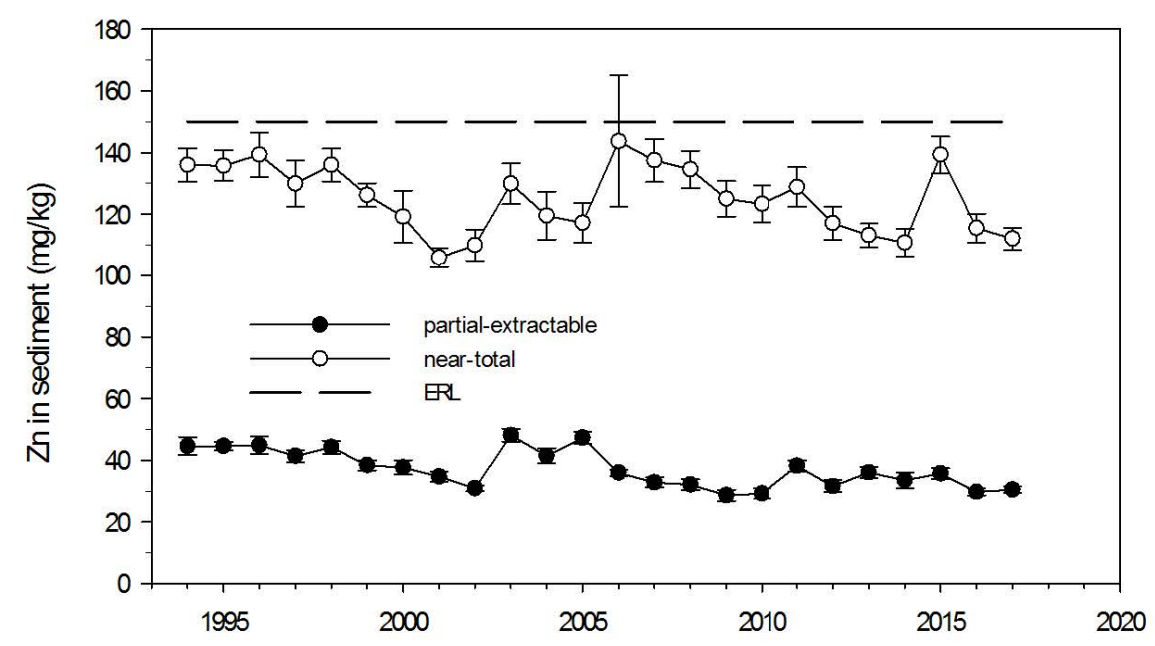

B.

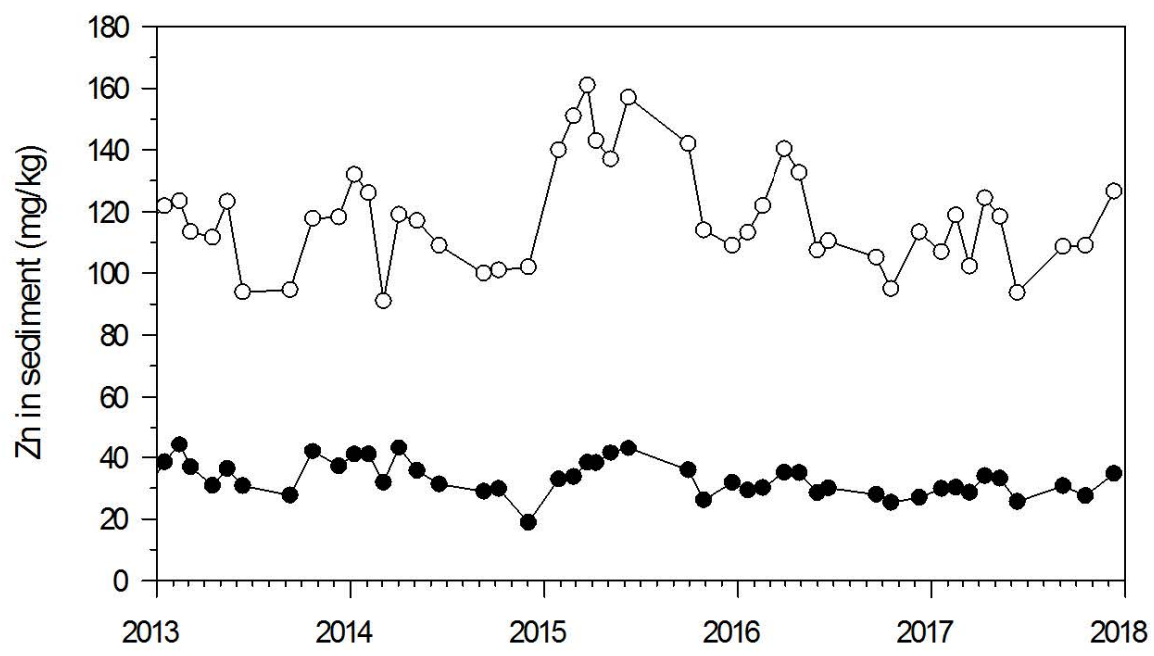

Figure 7. Zinc (Zn) in sediments, in milligrams per kilogram (mg/kg), Palo Alto, Calif., 1994-2017. A, Annual concentration of near-total and partial-extractable zinc for the period 1994-2017. Each value is the grand mean for nine samples per year with the standard error of those means (SEM). The dashed line is the effects range low (ERL), the concentration below which the expected incidence of adverse effects is low ( 9 percent). $B$, Data for the period 2013-2017. Data represent the mean values. 
A.

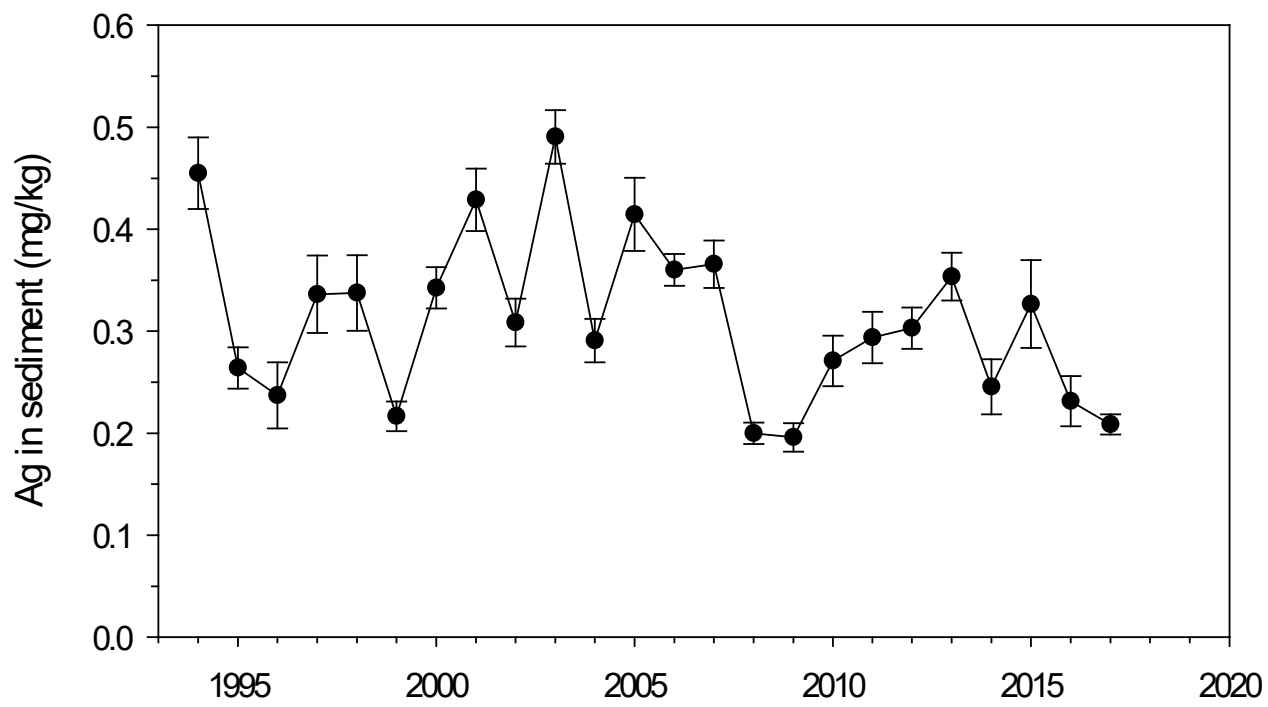

B.

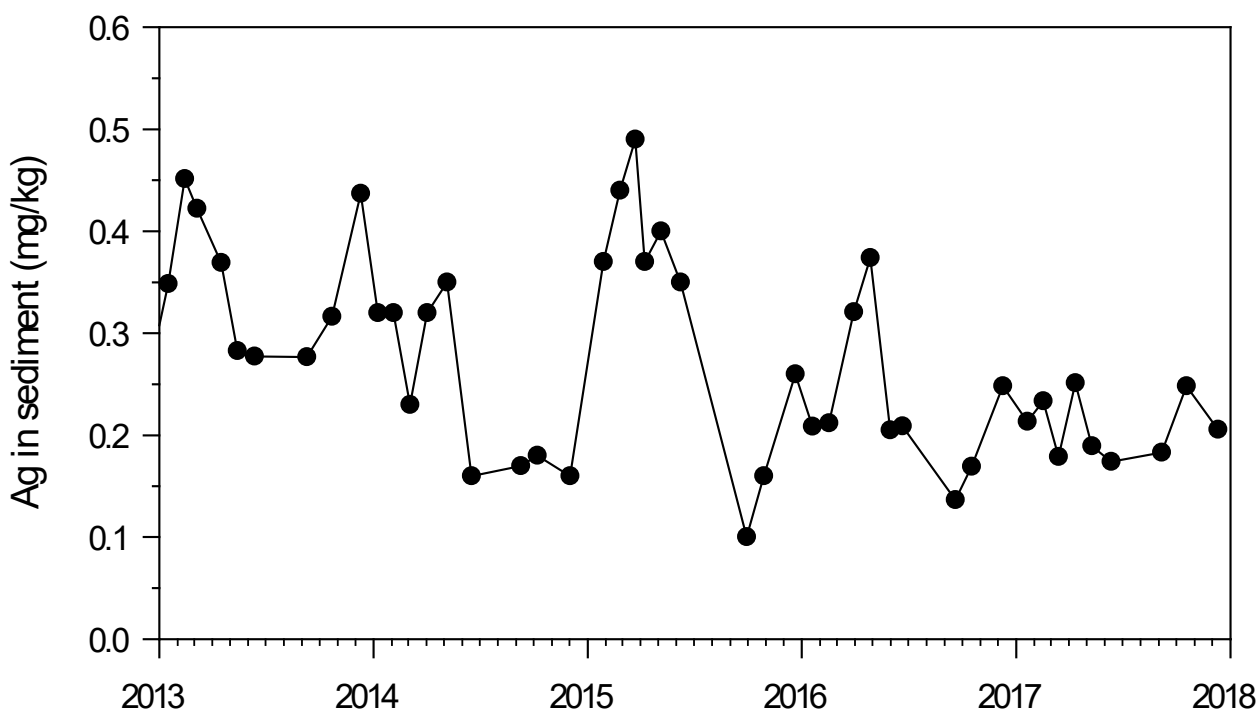

Figure 8. Silver (Ag) in sediments, in milligrams per kilogram (mg/kg), Palo Alto, Calif., 1994-2017. A, Annual concentration of silver for the period 1994-2017. Each value is the grand mean for nine samples per year with the standard error of those means (SEM). Data represent the annual mean with standard error (SEM). Data represent partial-extractable silver (treatment with $0.6 \mathrm{~N}$ hydrochloric acid). B, Data for the period 2013-2017. Data represent the mean values. 
A.

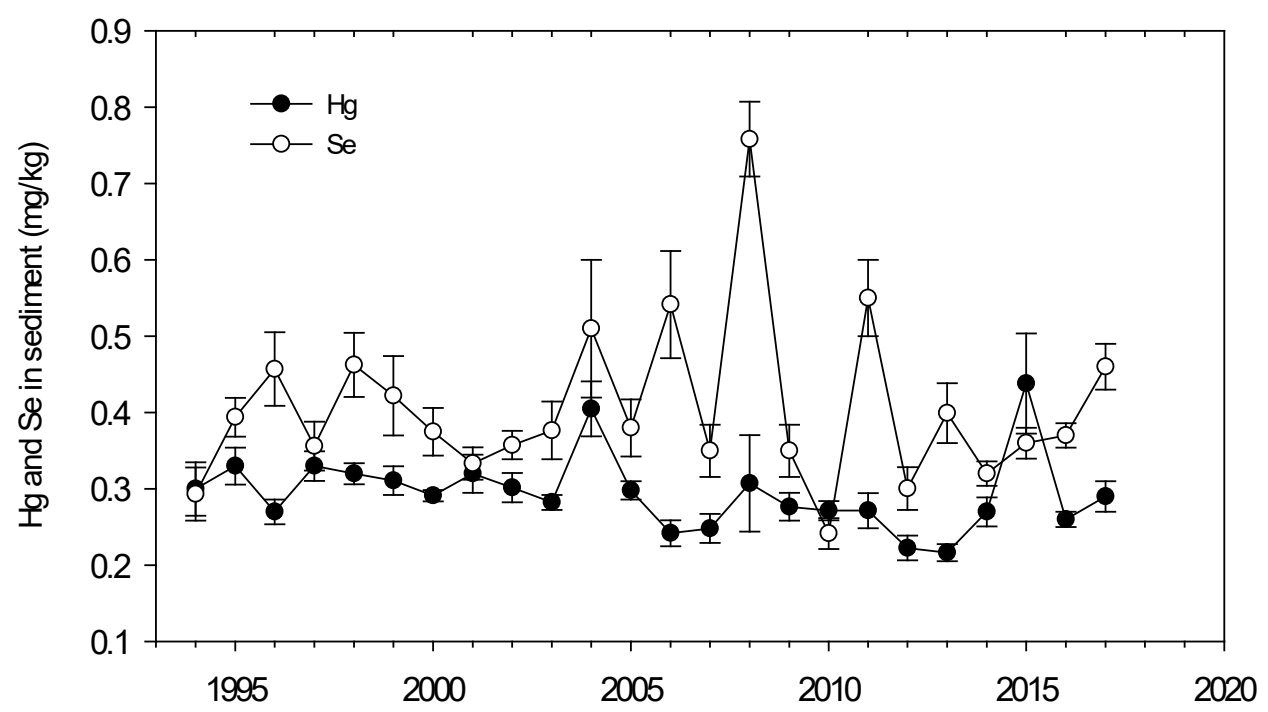

B.

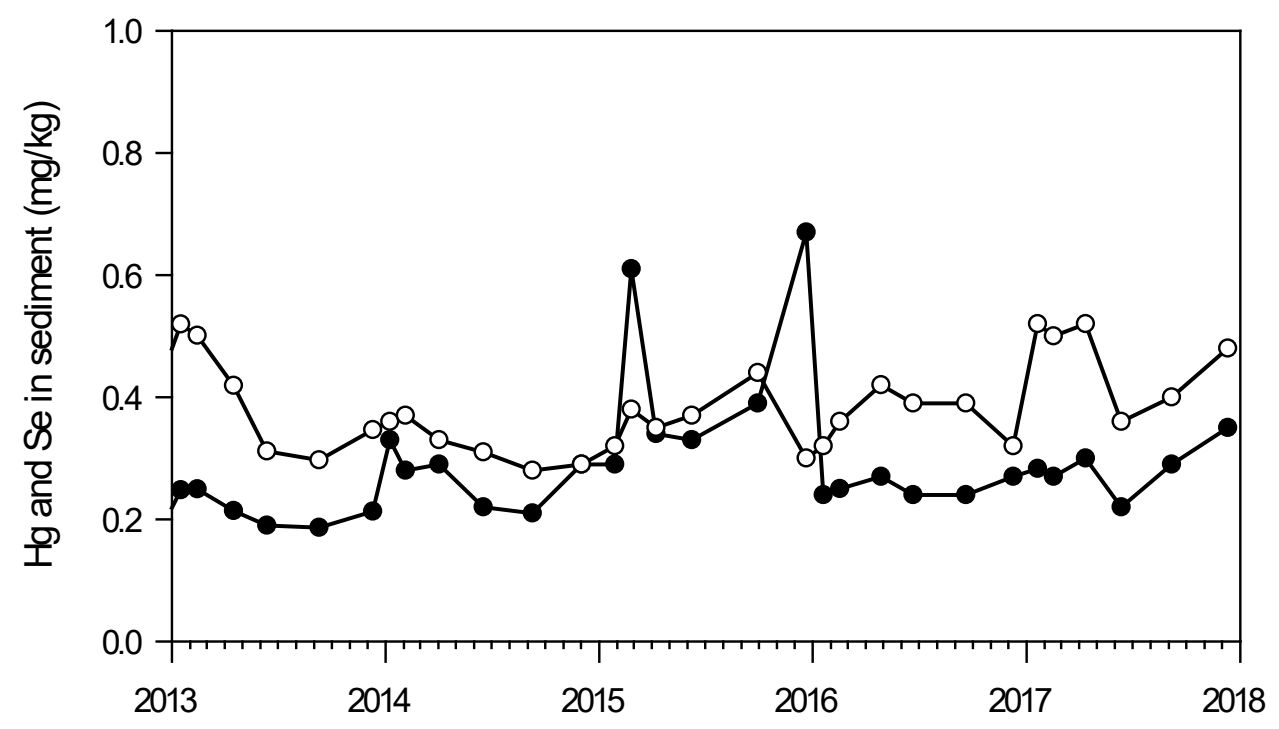

Figure 9. Mercury $(\mathrm{Hg})$ and selenium $(\mathrm{Se})$ in sediments, in milligrams per kilogram $(\mathrm{mg} / \mathrm{kg})$, Palo Alto, Calif., 1994-2017. A, Annual concentration of mercury and selenium for the period 1977-2017. Each value is the grand mean for 7-12 samples per year with the standard error of those means (SEM). B, Data for the period 2013-2017. Data represent the mean value. 
A.

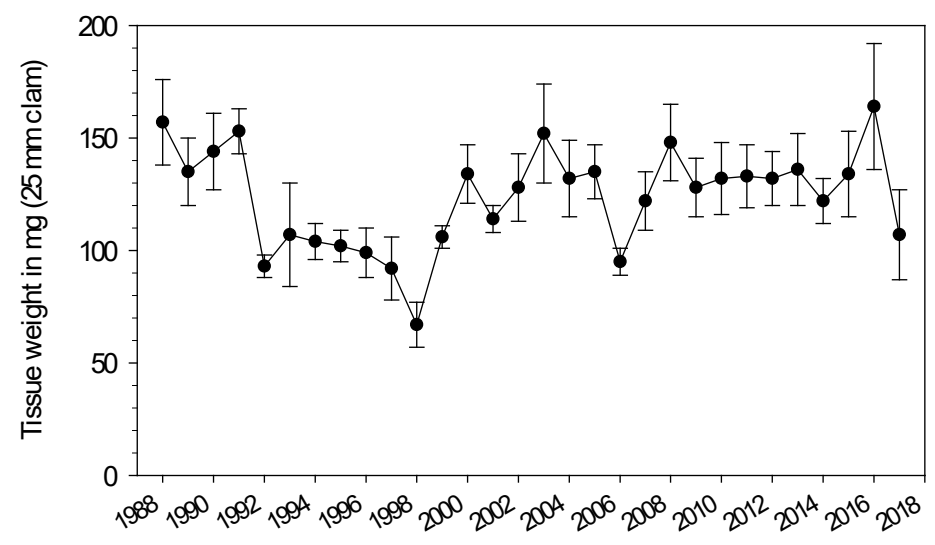

B.

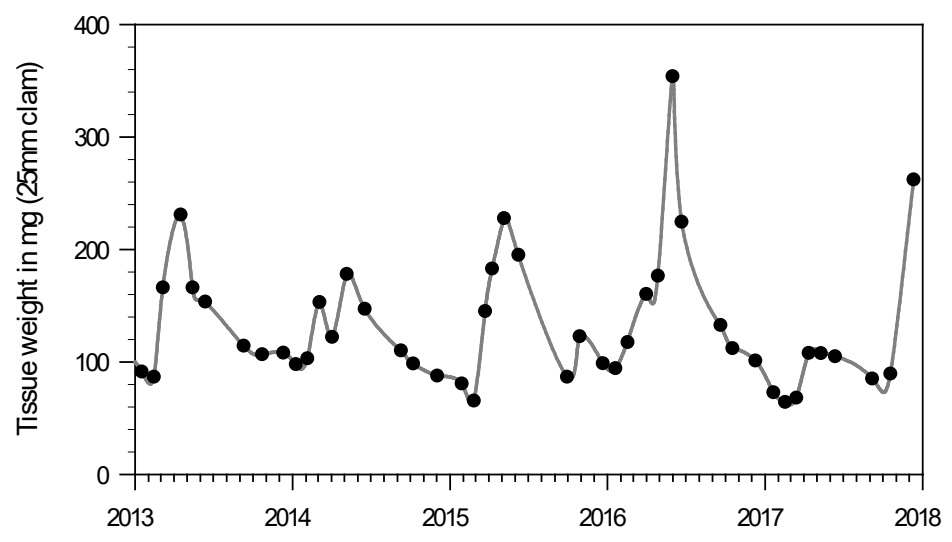

C.

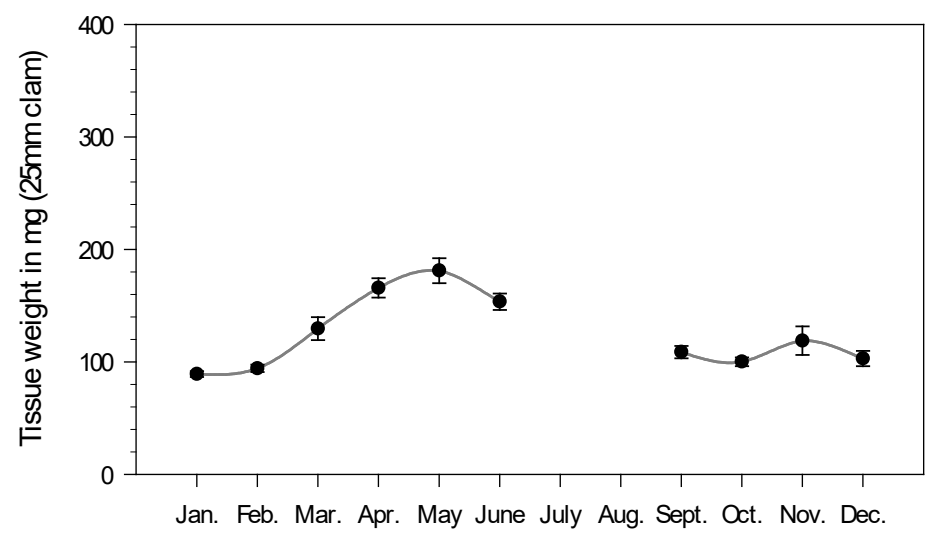

Figure 10. Condition index of the clam Macoma petalum, Palo Alto, Calif., 1988-2017. A, Annual condition index. The condition index is defined as the weight (milligrams) of the soft tissues for an individual clam having a shell length of 25 millimeters $(\mathrm{mm})$. Each value is the grand mean for nine samples with the standard error of the mean for those samples (SEM). B, Condition index over the period 2013-2017. C, The monthly mean of samples collected from 1988-2017, illustrating the general seasonal variation in condition index. The error bar is the SEM. Samples were not collected in July, August, and November after 1994, and any samples collected in those months prior to 1994 were not included for the purposes of the illustration. 
A.

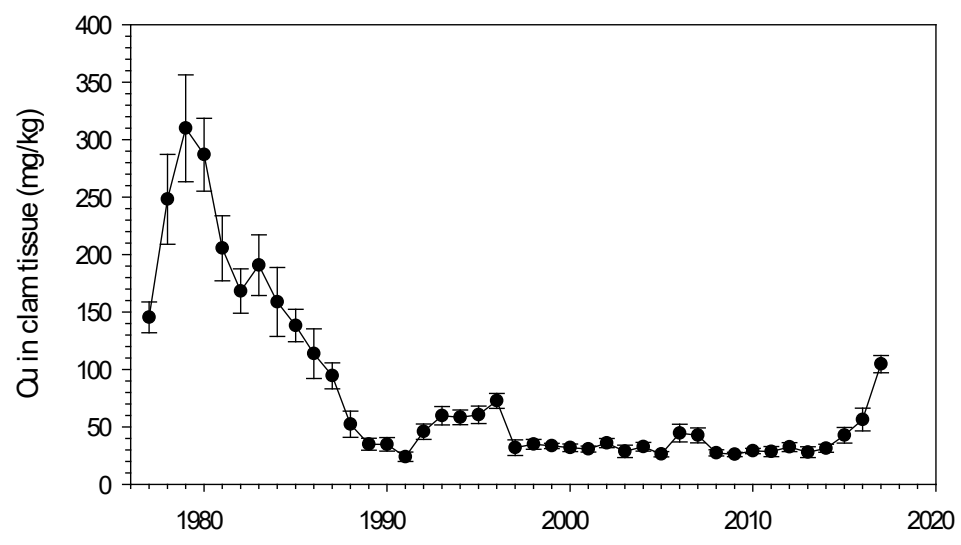

B.

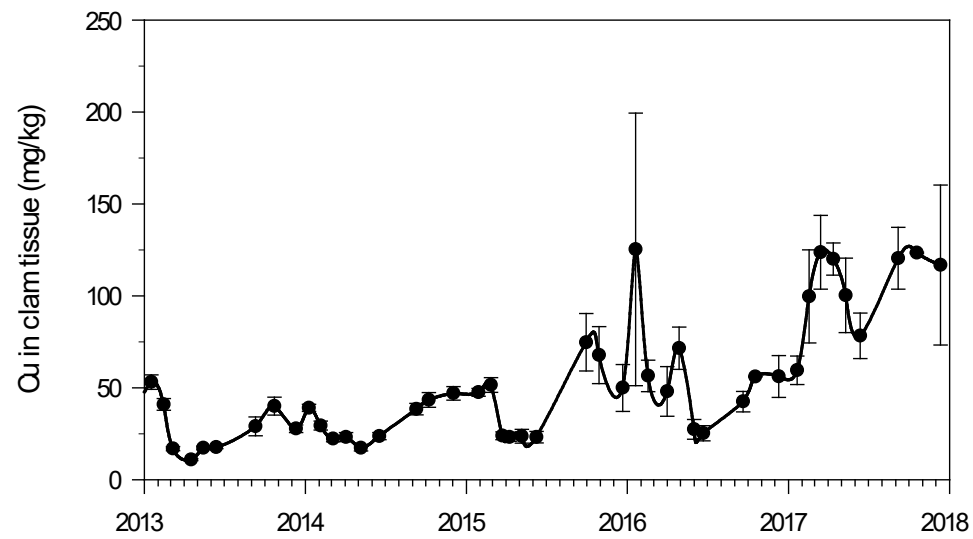

C.

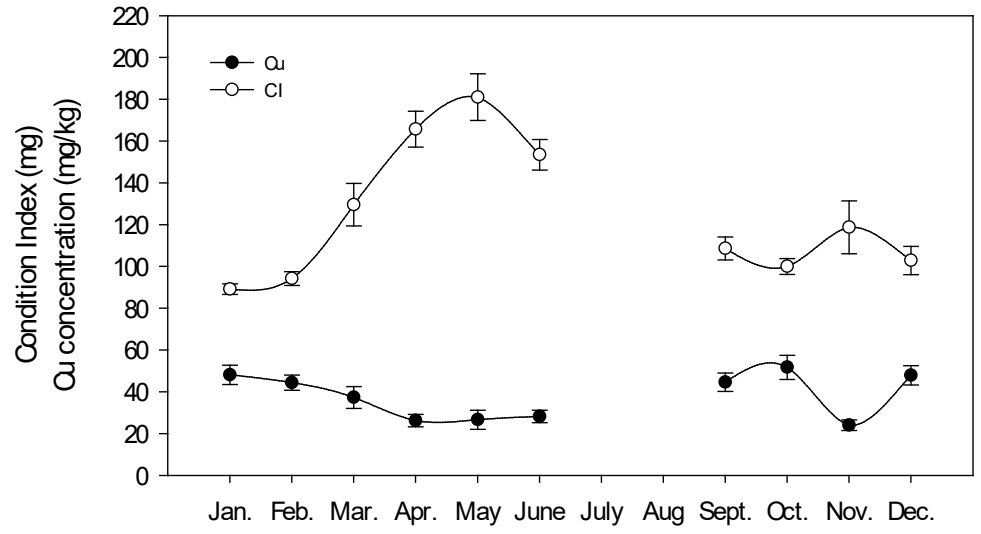

Figure 11. Copper (Cu) concentrations in the clam Macoma petalum in milligrams per kilogram (mg/kg), Palo Alto, Calif., 1977-2017. A, Annual concentration for the period 1977-2017. Each value is the grand mean for 7-12 samples per year with the standard error of those means (SEM). B, Data for the period 2013-2017. Each value represents the mean concentration for the sample collected on a given date. The error bar is the SEM. $C$, The monthly mean of all samples collected from 1994-2017, illustrating the general seasonal variation in copper and the condition index $(\mathrm{Cl})$. Collections are not made in July, August, and November. The error bar is the SEM. 
A.

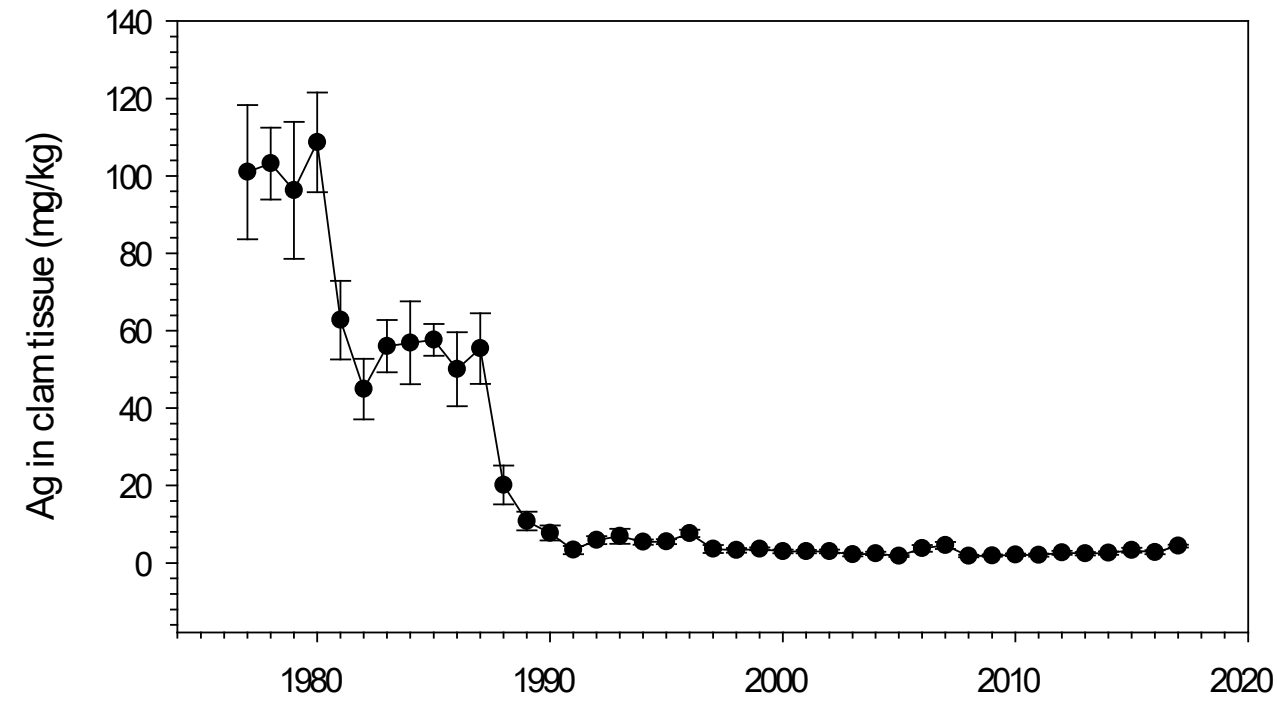

B.

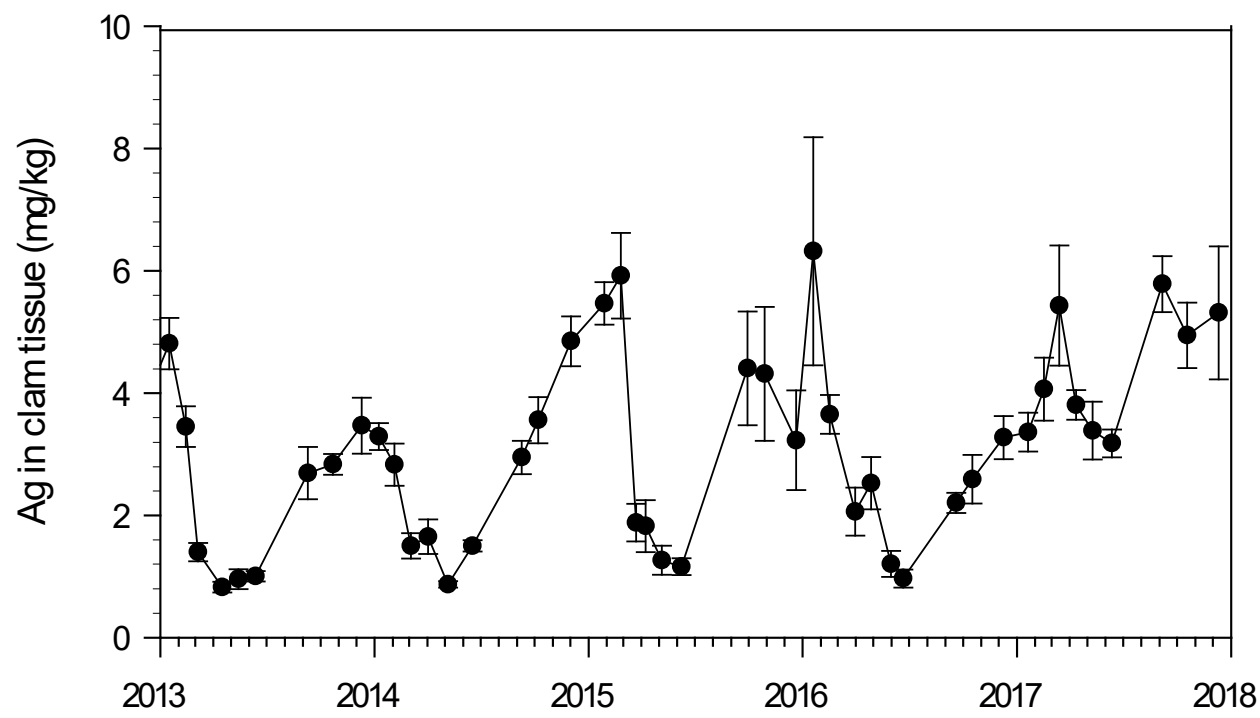

Figure 12. Silver (Ag) concentrations in the clam Macoma petalum in milligrams per kilogram $(\mathrm{mg} / \mathrm{kg})$, Palo Alto, Calif., 1997-2017. A, Annual concentration for the period 1977-2017. Each value is the grand mean for 7-12 samples per year with the standard error of those means (SEM). B, Data for the period 2013-2017. Each value represents the mean concentration for the sample collected on a given date. The error bar is the SEM. 
A.

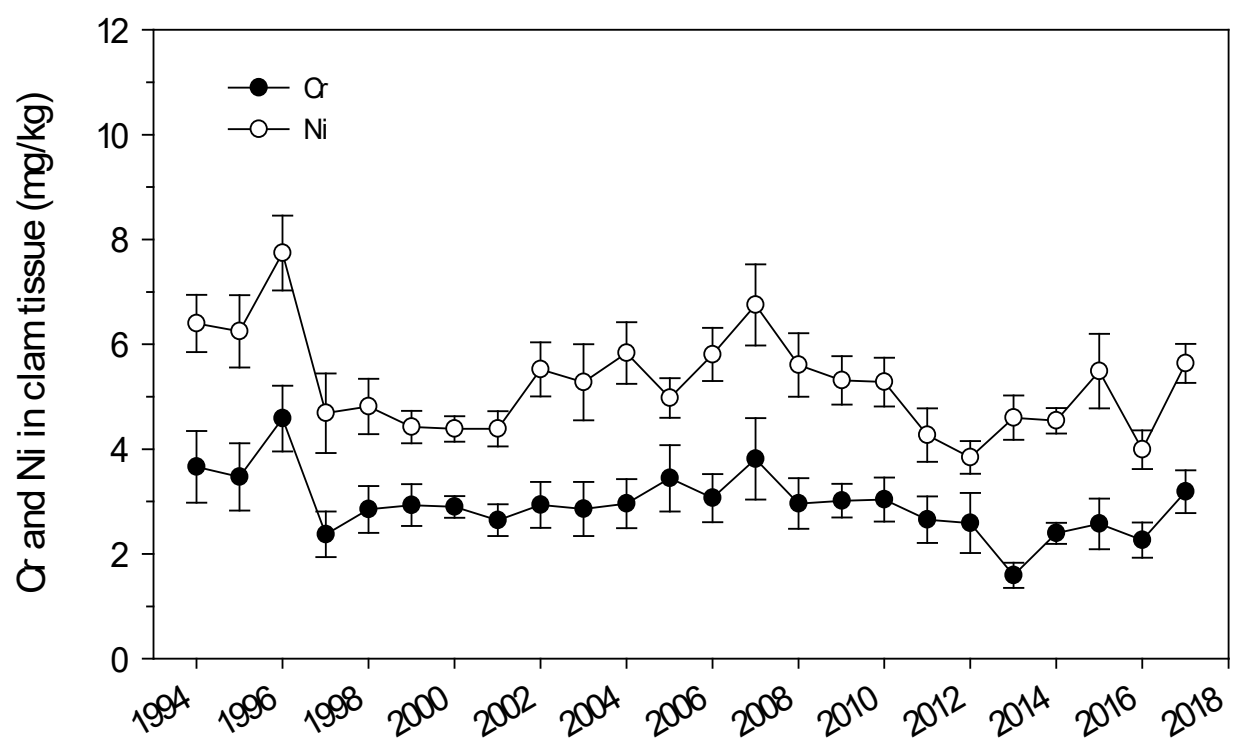

B.

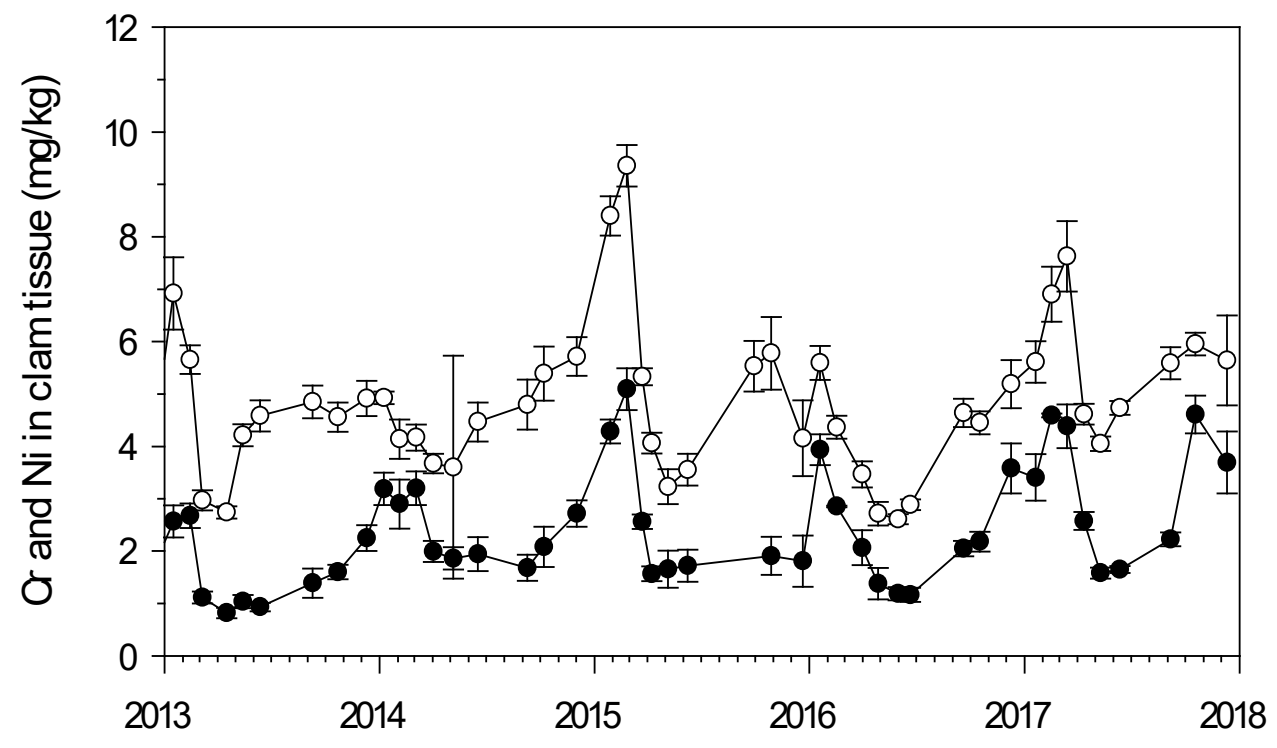

Figure 13. Chromium ( $\mathrm{Cr}$ ) and nickel (Ni) concentrations, in milligrams per kilogram $(\mathrm{mg} / \mathrm{kg})$, in the clam Macoma petalum, Palo Alto, Calif., 1994-2017. A, Annual concentration of chromium and nickel for the period 1994-2017. Each value is the grand mean concentration for 7-12 samples per year with the standard error of those means (SEM). B, Data for the period 2013-2017. Each value represents the mean concentration for the sample collected on a given date. The error bar is the SEM. 
A.

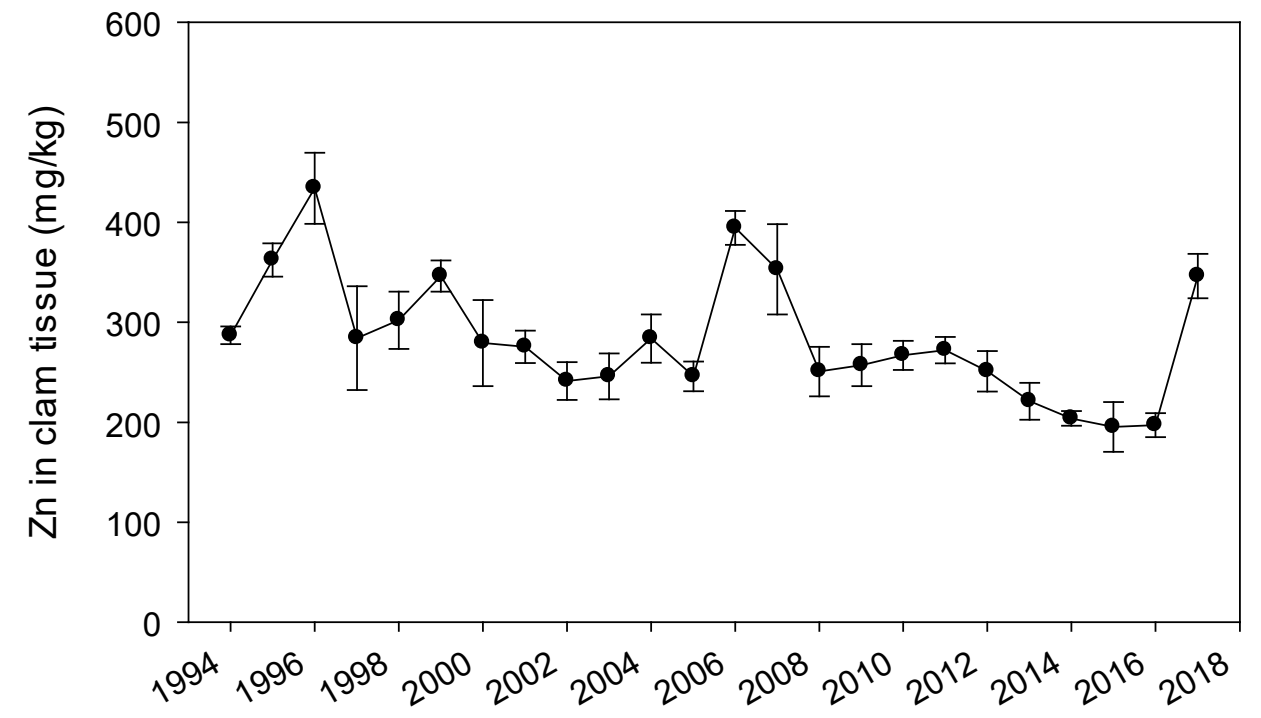

B.

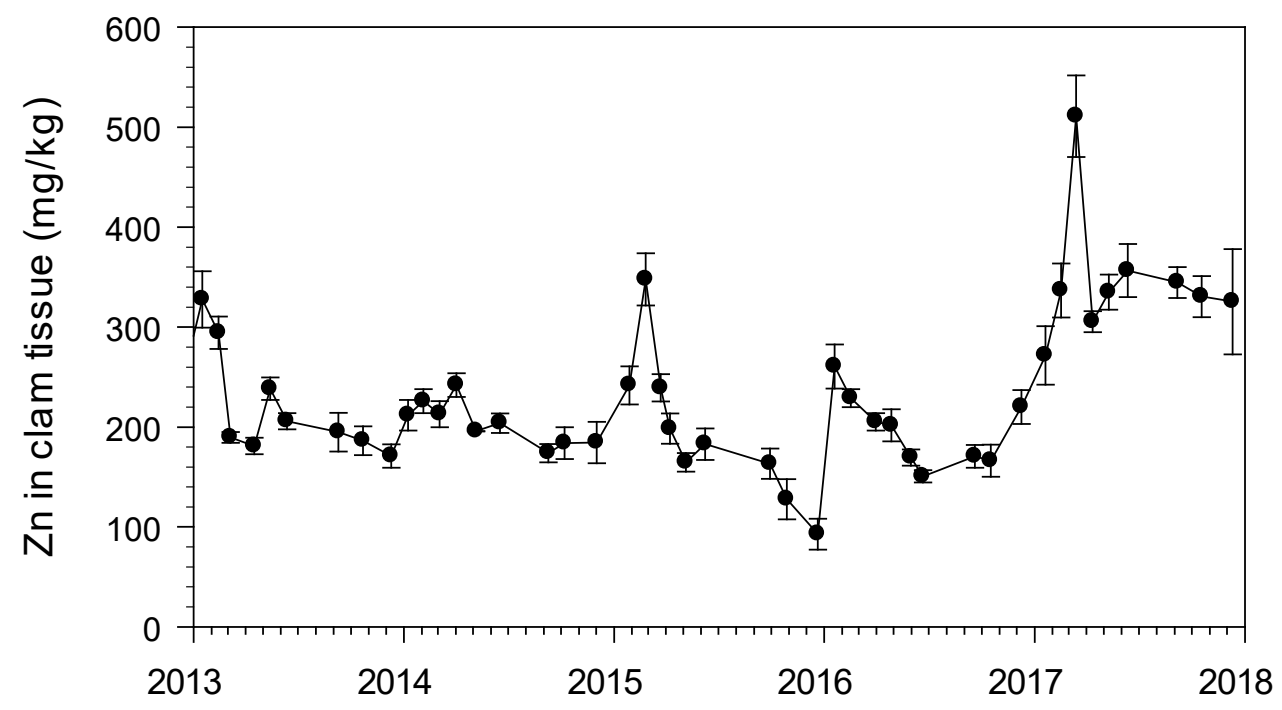

Figure 14. Zinc (Zn) concentrations, in milligrams per kilogram ( $\mathrm{mg} / \mathrm{kg})$, in the clam Macoma petalum, Palo Alto, Calif., 1994-2017. A, Annual concentration of zinc. Each value is the grand mean concentration for 7-12 samples per year with the standard error of those means (SEM). B, Data for the period 2013-2017. Each value represents the mean concentration for the sample collected on a given date. The error bar is the SEM. 
A.

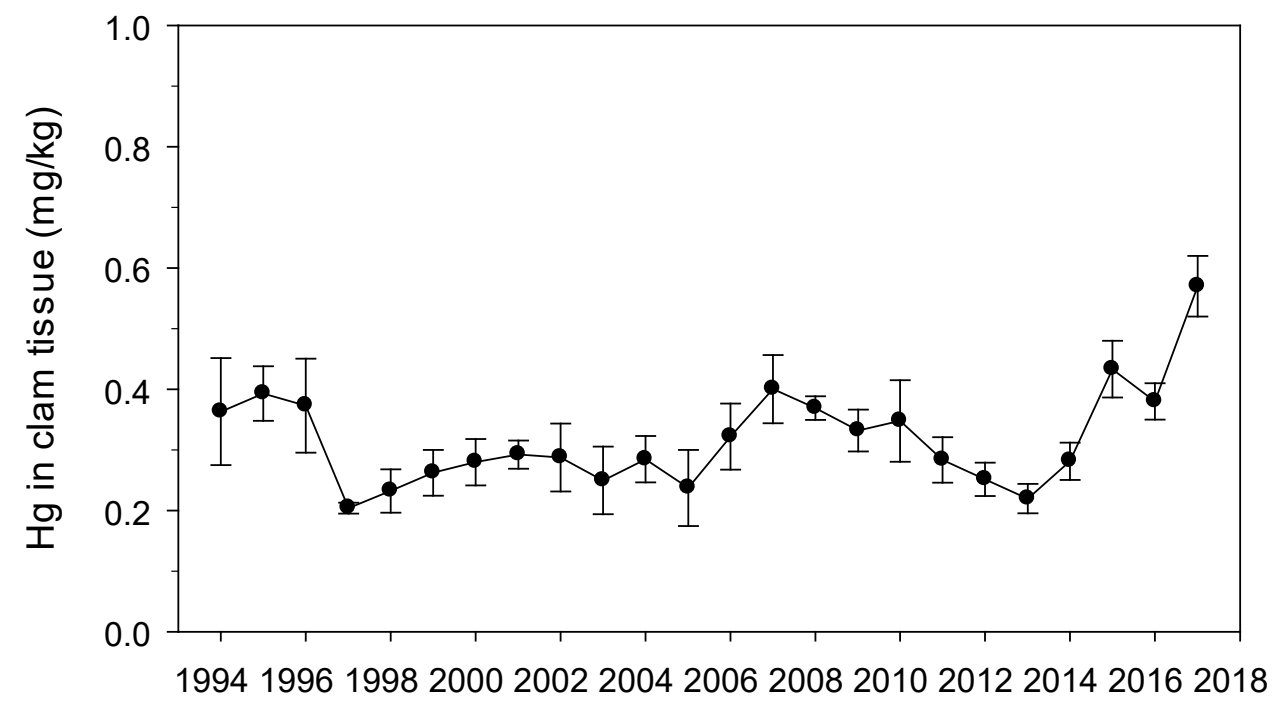

B.

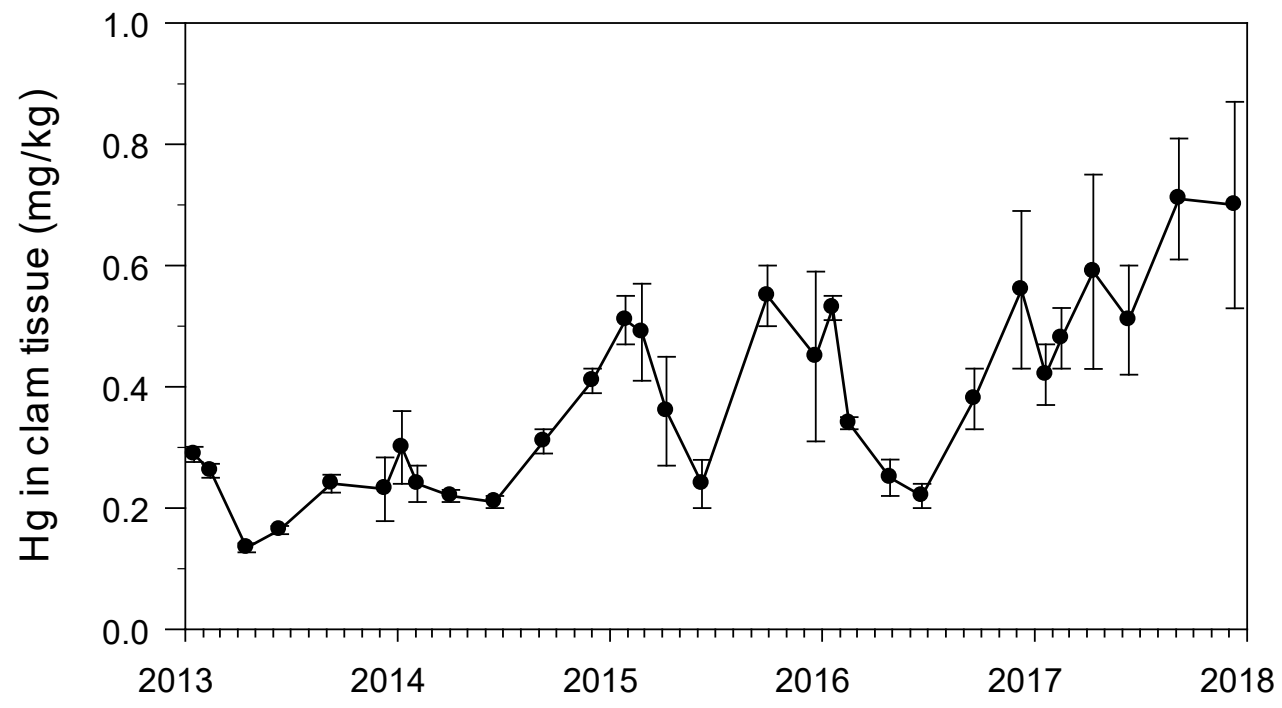

Figure 15. Mercury $(\mathrm{Hg})$ concentrations, in milligrams per kilogram $(\mathrm{mg} / \mathrm{kg})$, in the clam Macoma petalum, Palo Alto, Calif., 1994-2017. A, Annual concentration of mercury. Each value is the grand mean concentration for six samples per year with the standard error of those means (SEM). B, Data for the period 2013-2017. Each value represents the mean concentration for the sample collected on a given date. The error bar is the SEM. 
A.

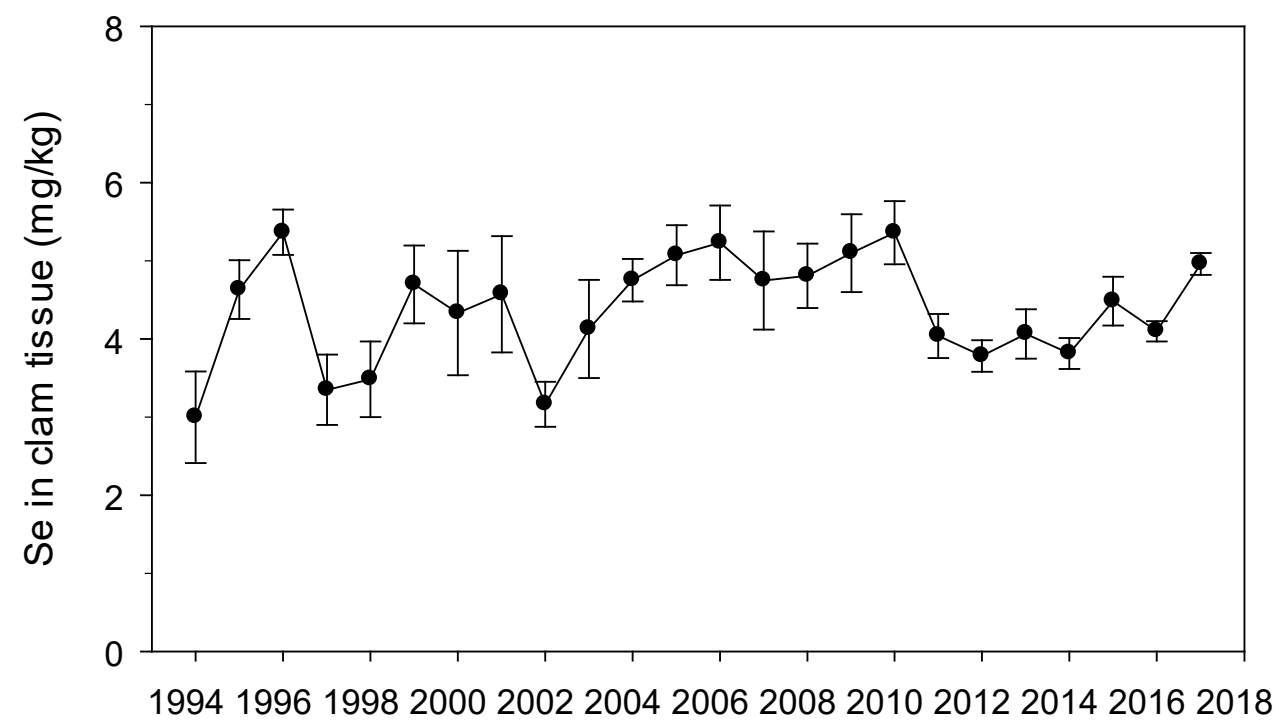

B.

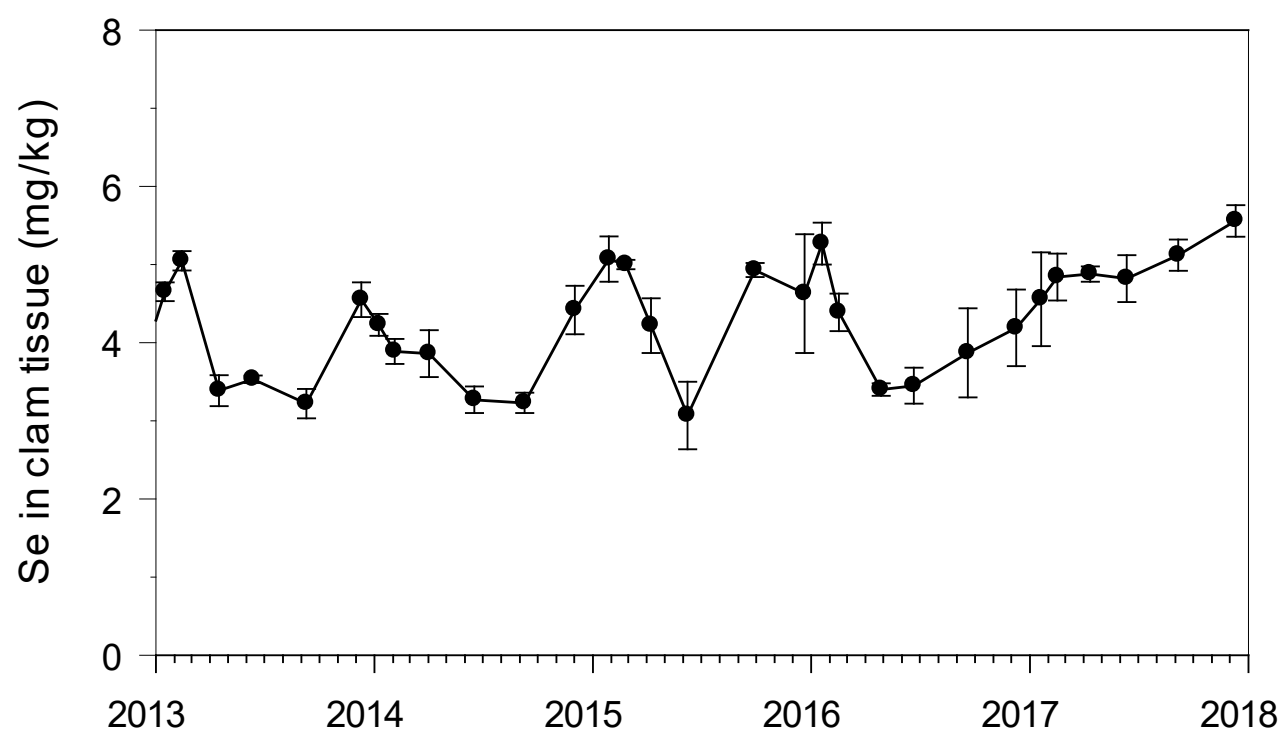

Figure 16. Selenium (Se) concentrations, in milligrams per kilogram (mg/kg), in the clam Macoma petalum, Palo Alto, Calif., 1994-2017. A, Annual concentration of selenium. Each value is the grand mean concentration for 6 samples per year with the standard error of those means (SEM). B, Data for the period 2013-2017. Each value represents the mean concentration for the sample collected on a given date. The error bar is the SEM. 


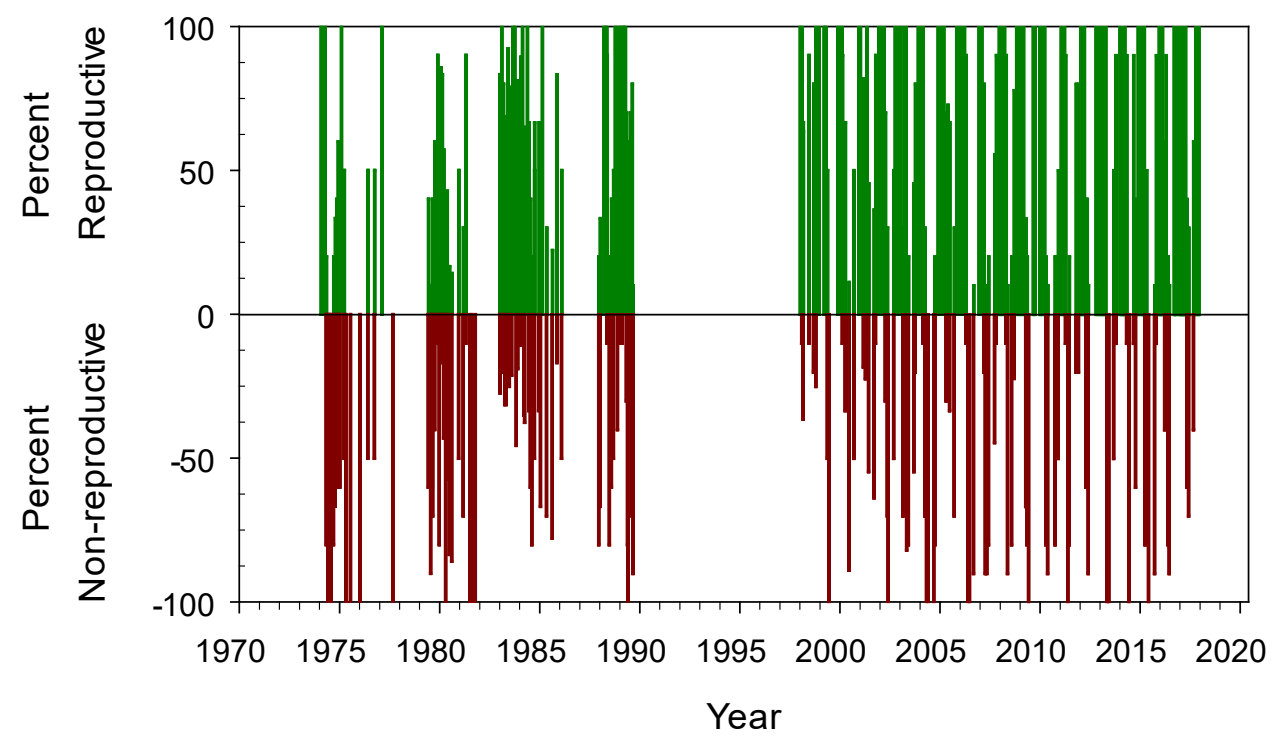

Figure 17. Reproductive activity of the clam Macoma petalum, Palo Alto, Calif., 1974-2017. Values are the percent of individuals that were either reproductively inactive (non-reproductive; shown in red) or in various stages of reproduction (reproductive; shown in green). The percent of non-reproductive individuals is reported as a negative value.

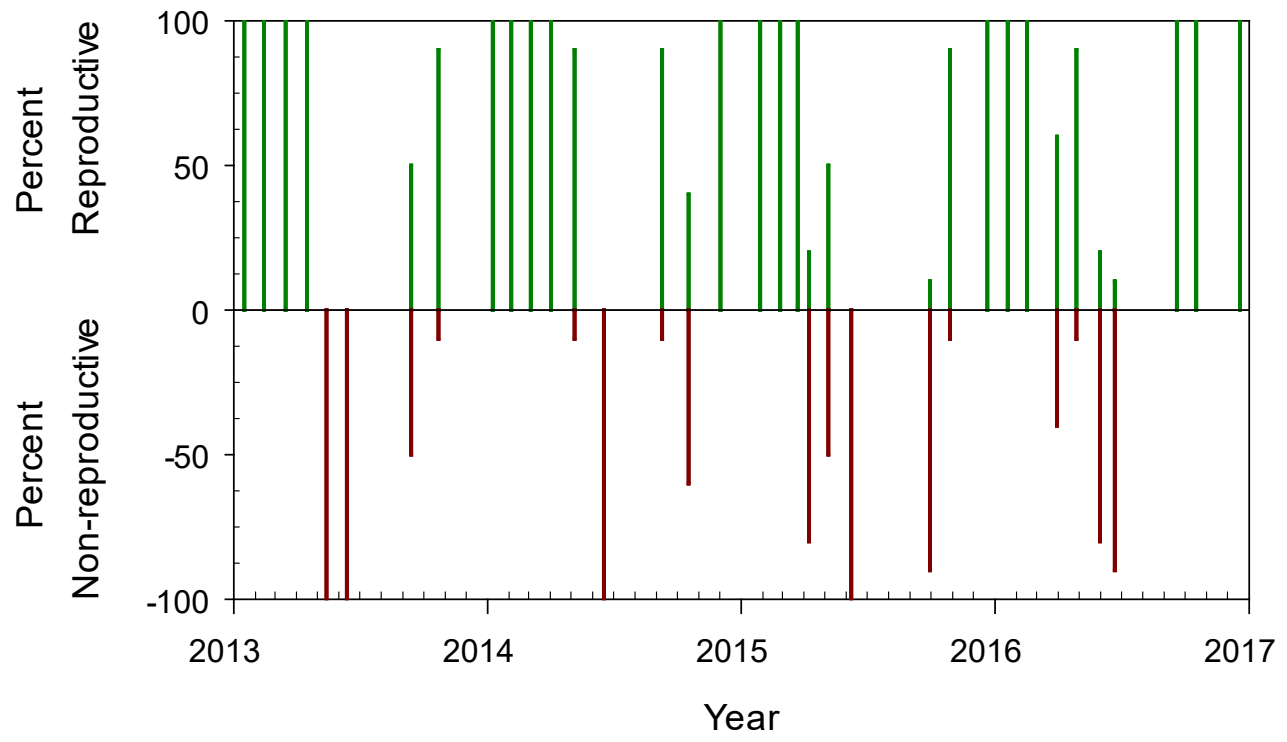

Figure 18. Reproductive activity of the clam Macoma petalum, Palo Alto, Calif., 2013-2017. Values are the percent of individuals that were either reproductively inactive (non-reproductive; shown as a negative value) or in various stages of reproduction (reproductive; shown as a positive value). 
A.

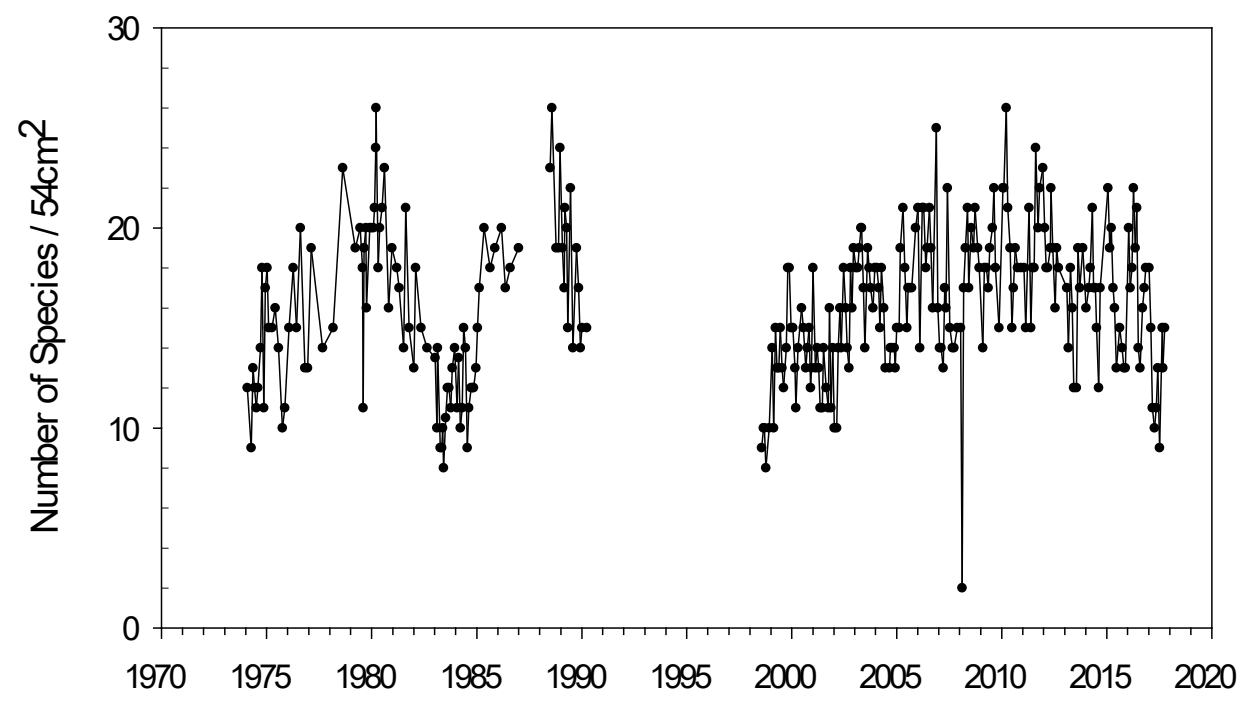

B.

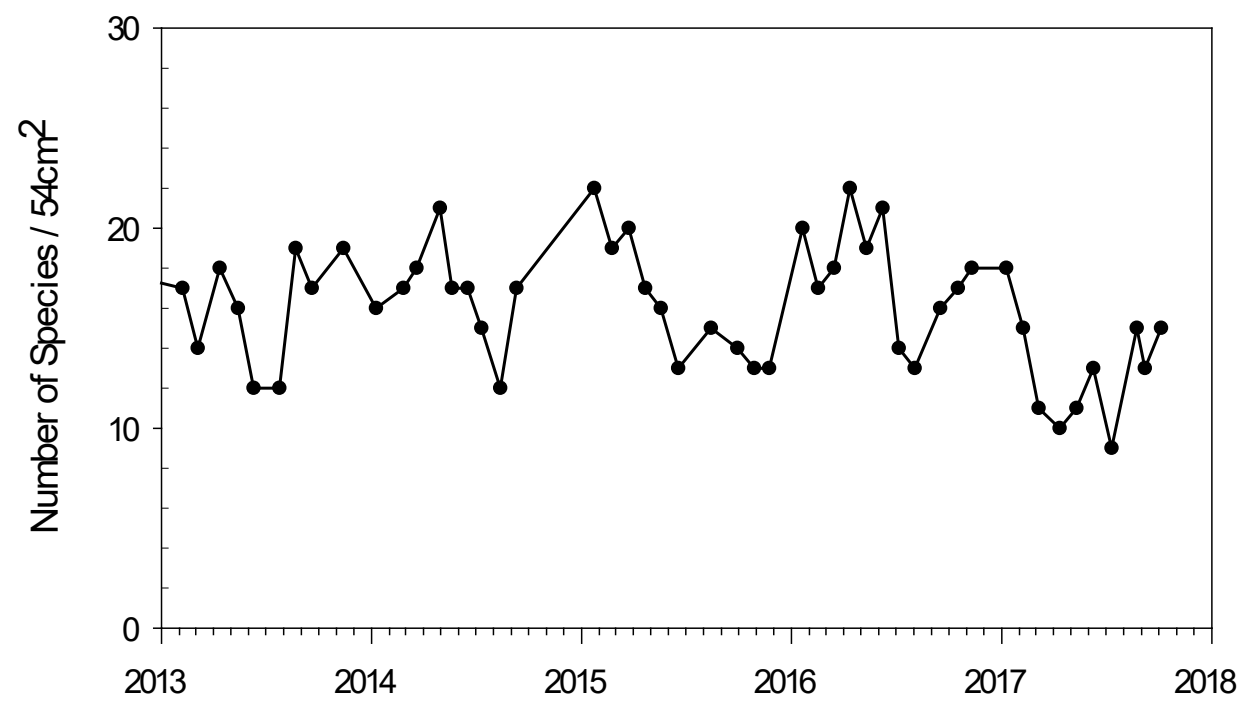

Figure 19. Total number of species present at the Palo Alto site, Calif., $(A)$ 1974-2017 and (B) 2013-2017. Collections were not made between 1991 and 1998. Cm, centimeters. 
A.

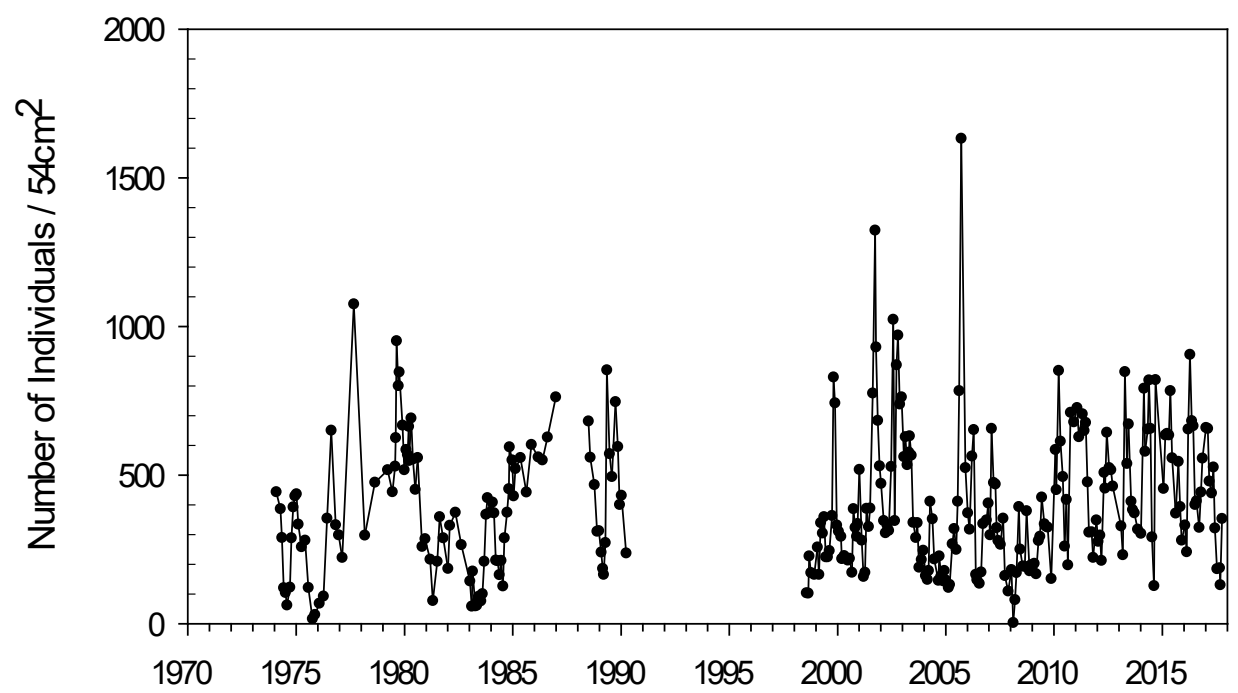

B.

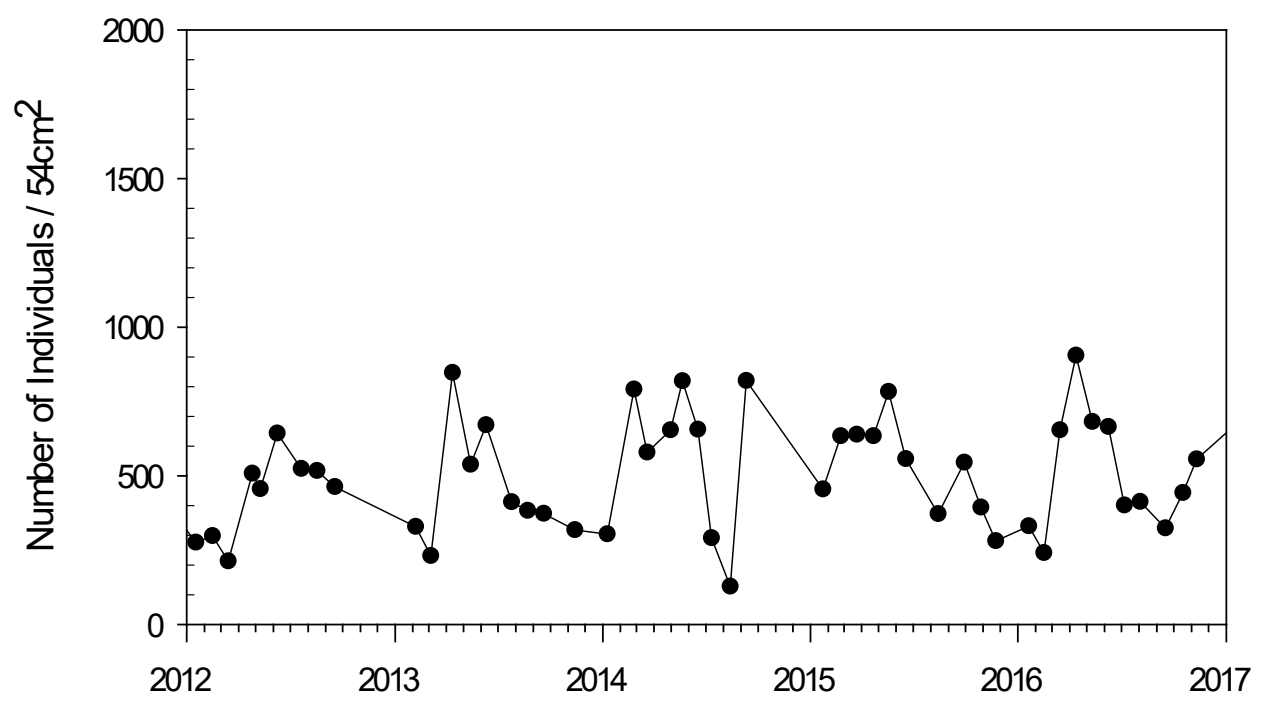

Figure 20. Total average number of individuals present at the Palo Alto site, Calif., (A) 1974-2017 and (B) 20122017. Collections were not made between 1991 and 1998. Cm, centimeters. 
A.

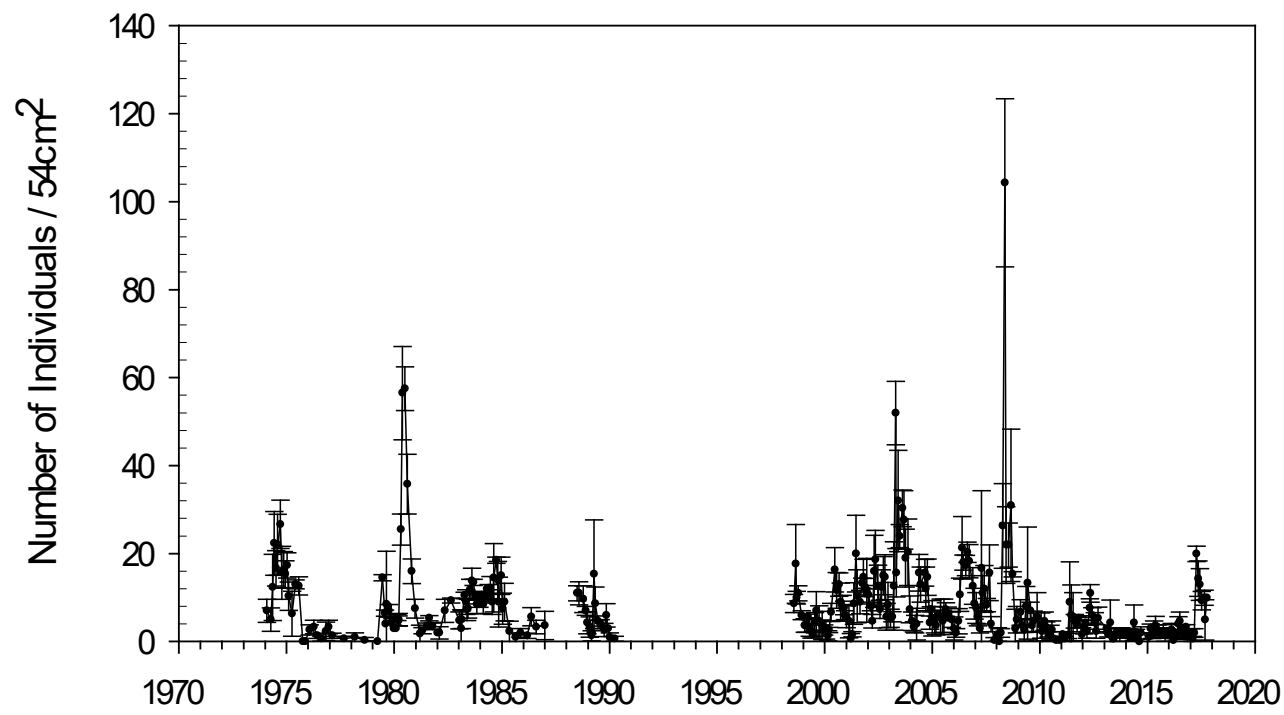

B.

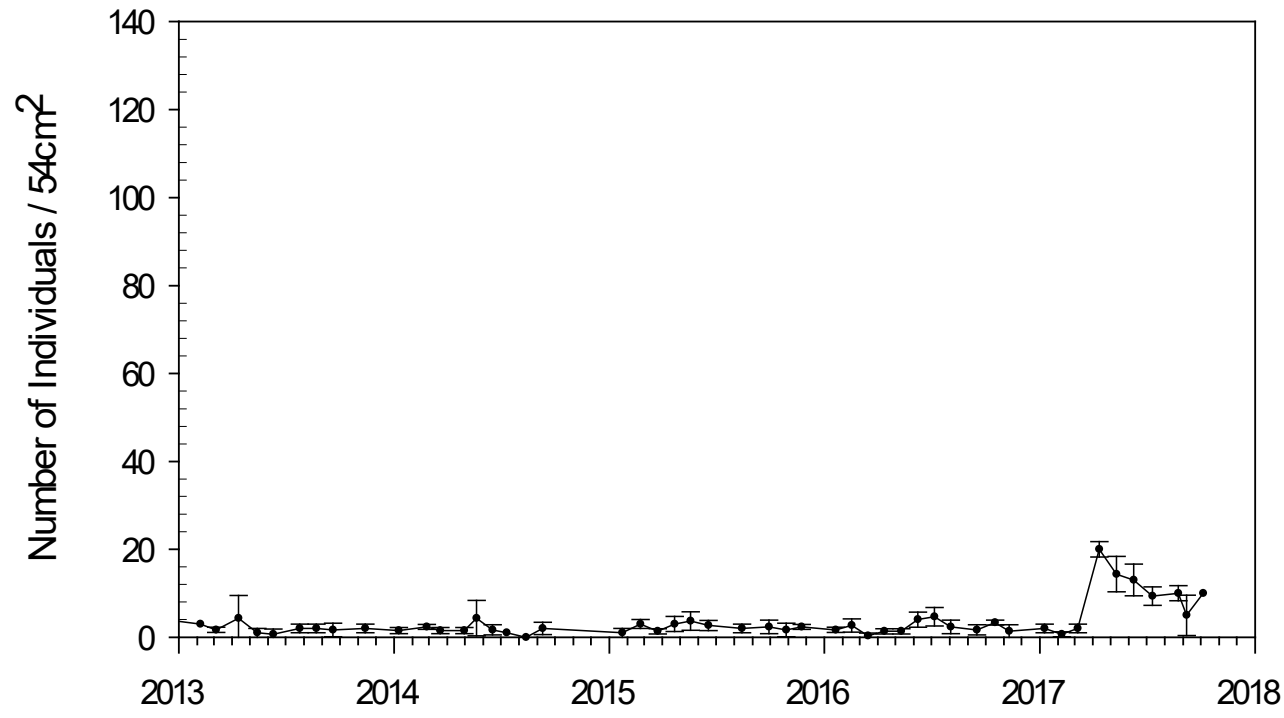

Figure 21. Monthly average abundance of Macoma petalum, Palo Alto, Calif., (A) 1974-2017 and (B) 2013-2017. Error bars represent standard deviation from three replicate samplings. Collections were not made between 1991 and 1998. Cm, centimeters. 
A.

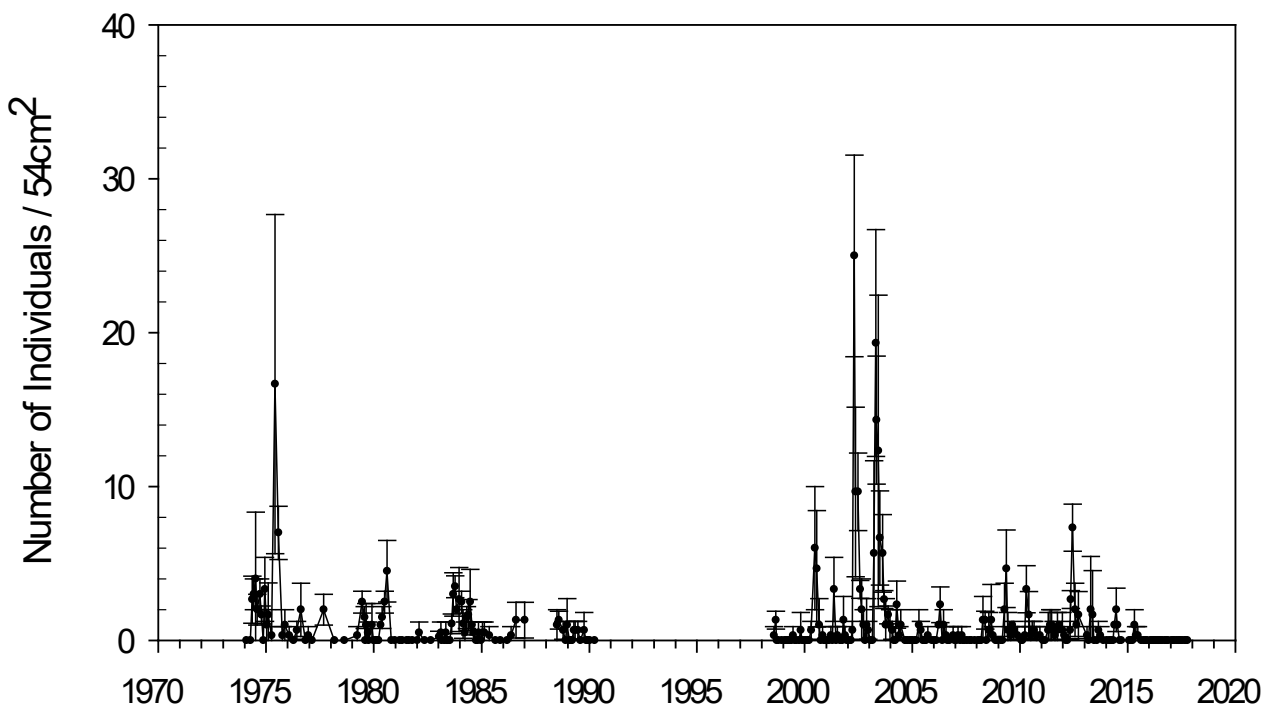

B.

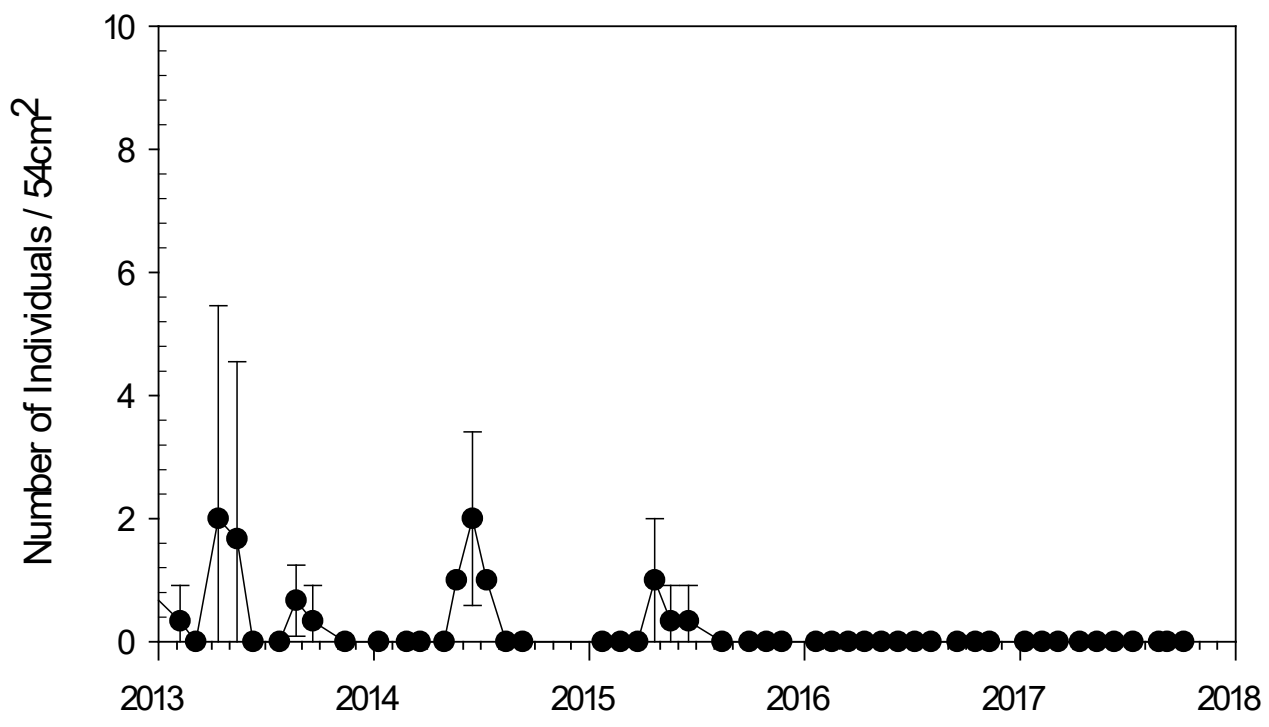

Figure 22. Monthly average abundance of Mya arenaria, Palo Alto, Calif., (A) 1974-2017 and (B) 2013-2017. Error bars represent standard deviation from three replicate samplings. Collections were not made between 1991 and 1998. Cm, centimeters. 


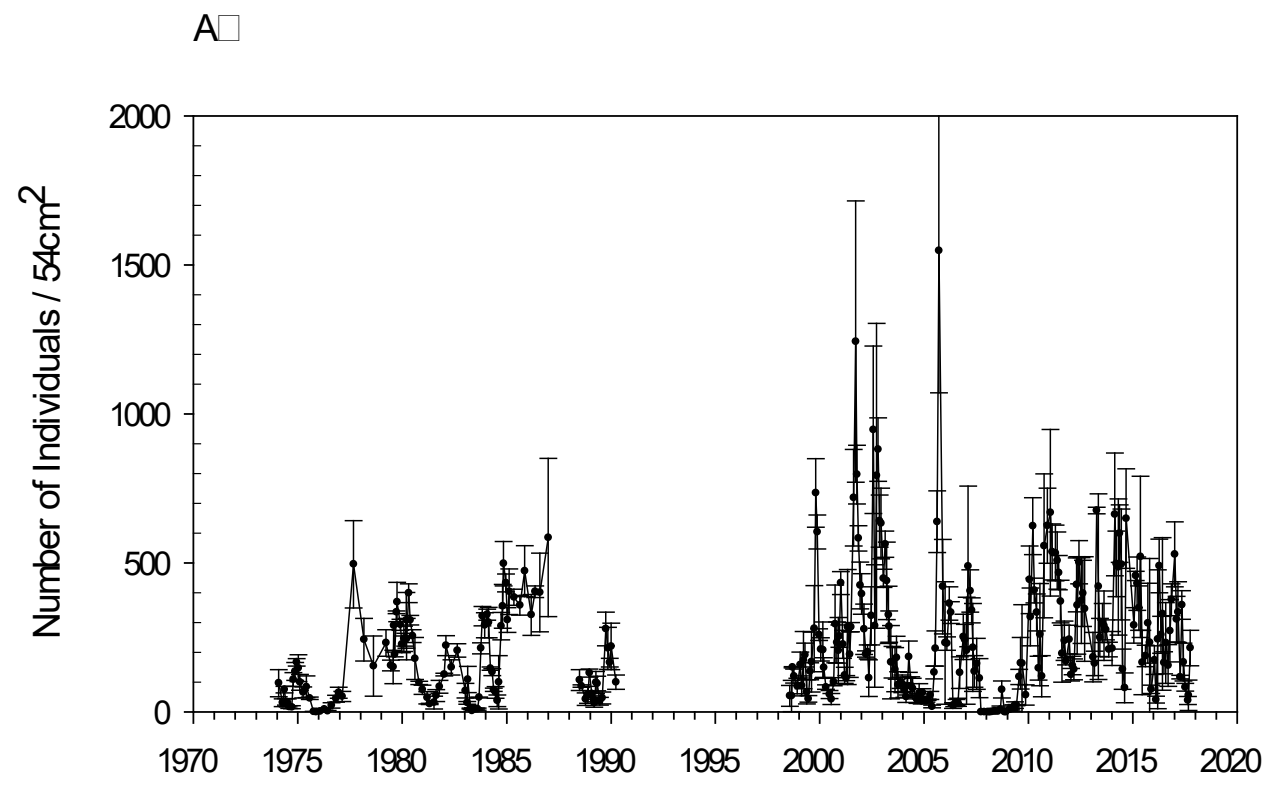

B.

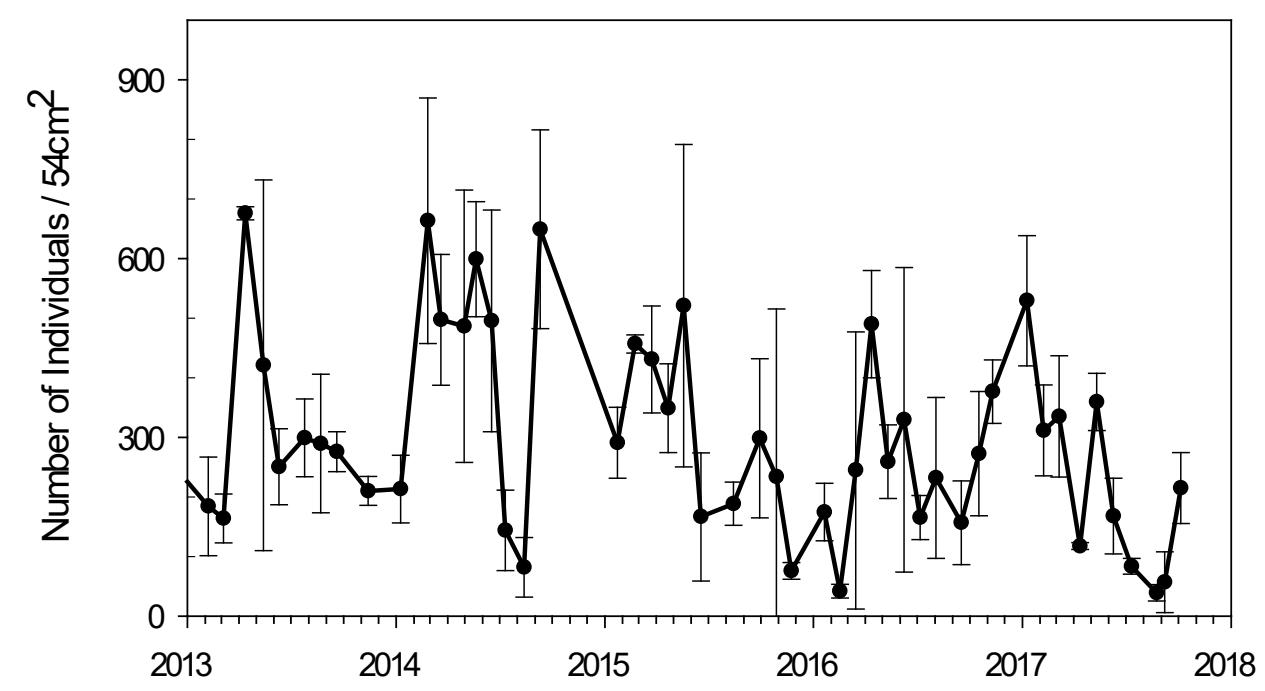

Figure 23. Monthly average abundance of Gemma gemma, Palo Alto, Calif., (A) 1974-2017 and (B) 2013-2017. Error bars represent standard deviation from three replicate samplings. Collections were not made between 1991 and 1998. Cm, centimeters. 
A.

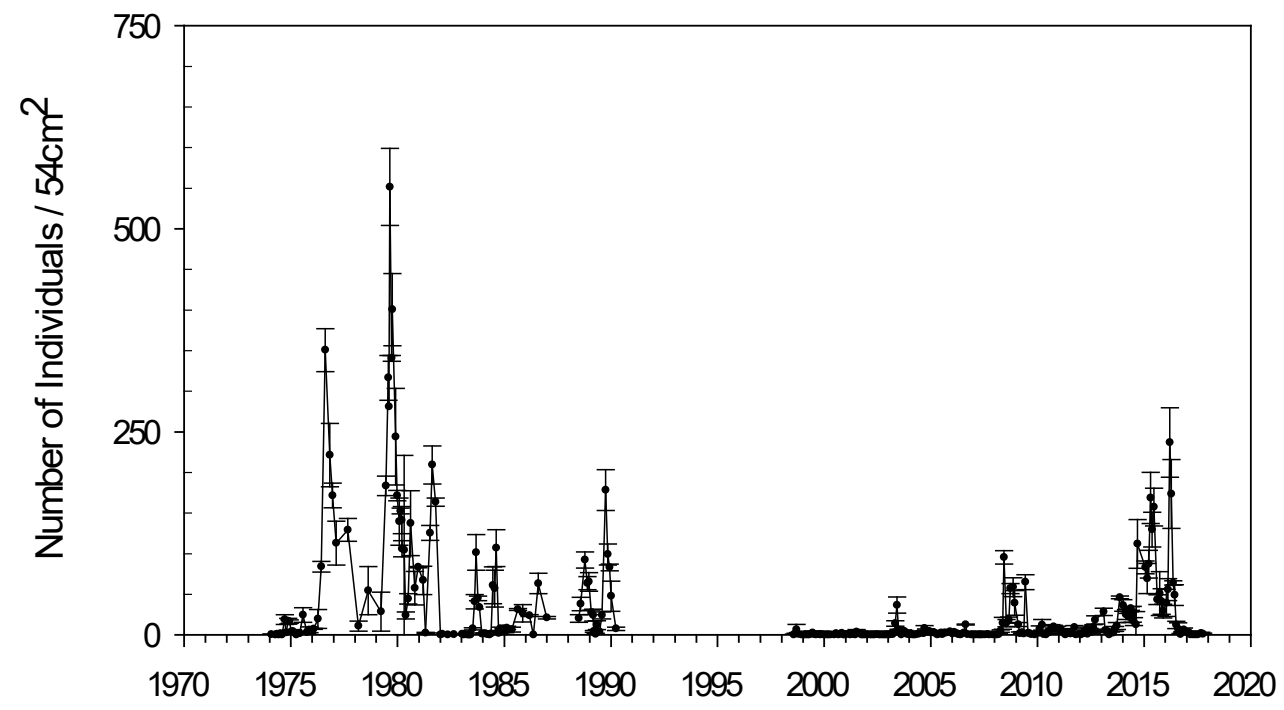

B.

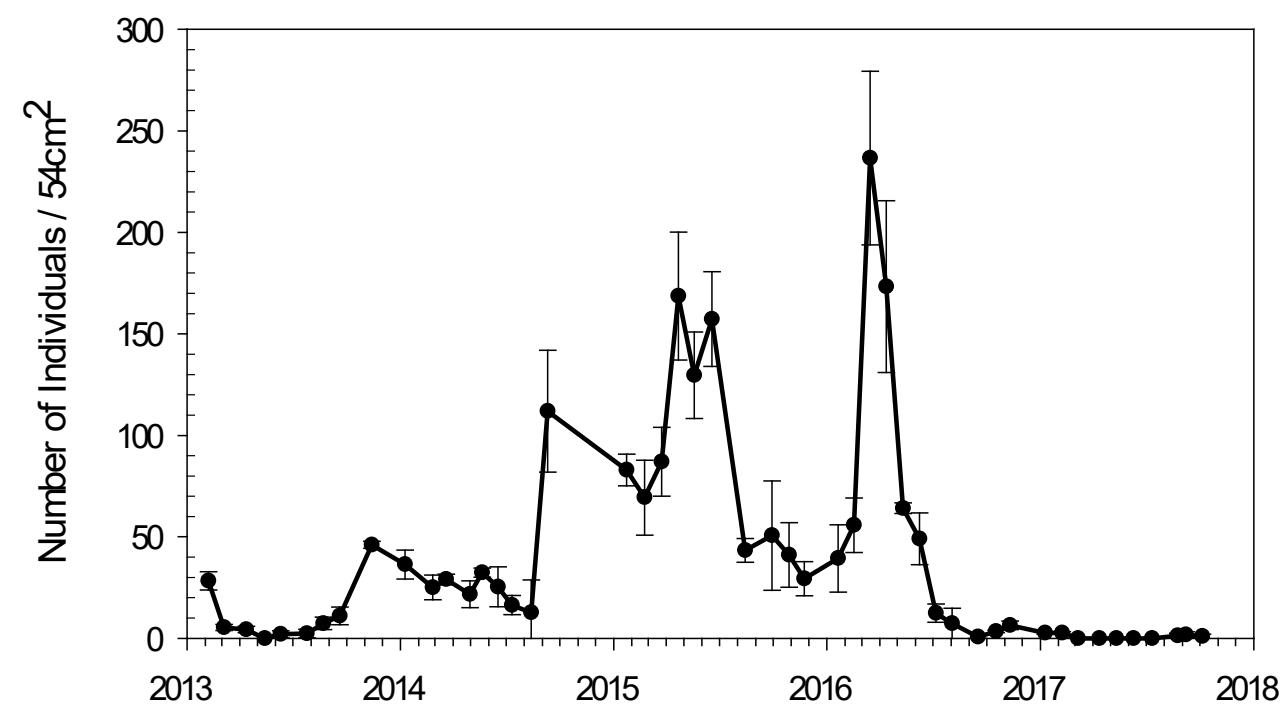

Figure 24. Monthly average abundance of Ampelisca abdita, Palo Alto, Calif., (A) 1974-2017 and (B) 2013-2017. Error bars represent standard deviation from three replicate samplings. Collections were not made between 1991 and 1998. Cm, centimeters. 
A.

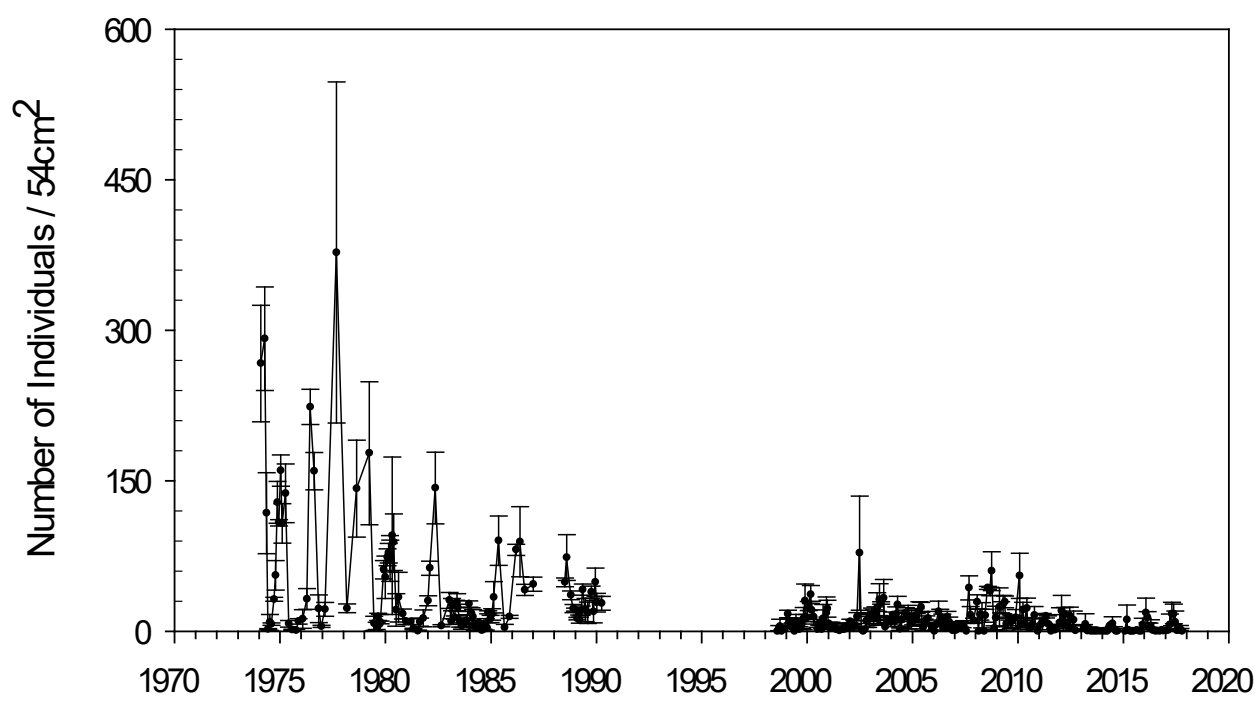

B.

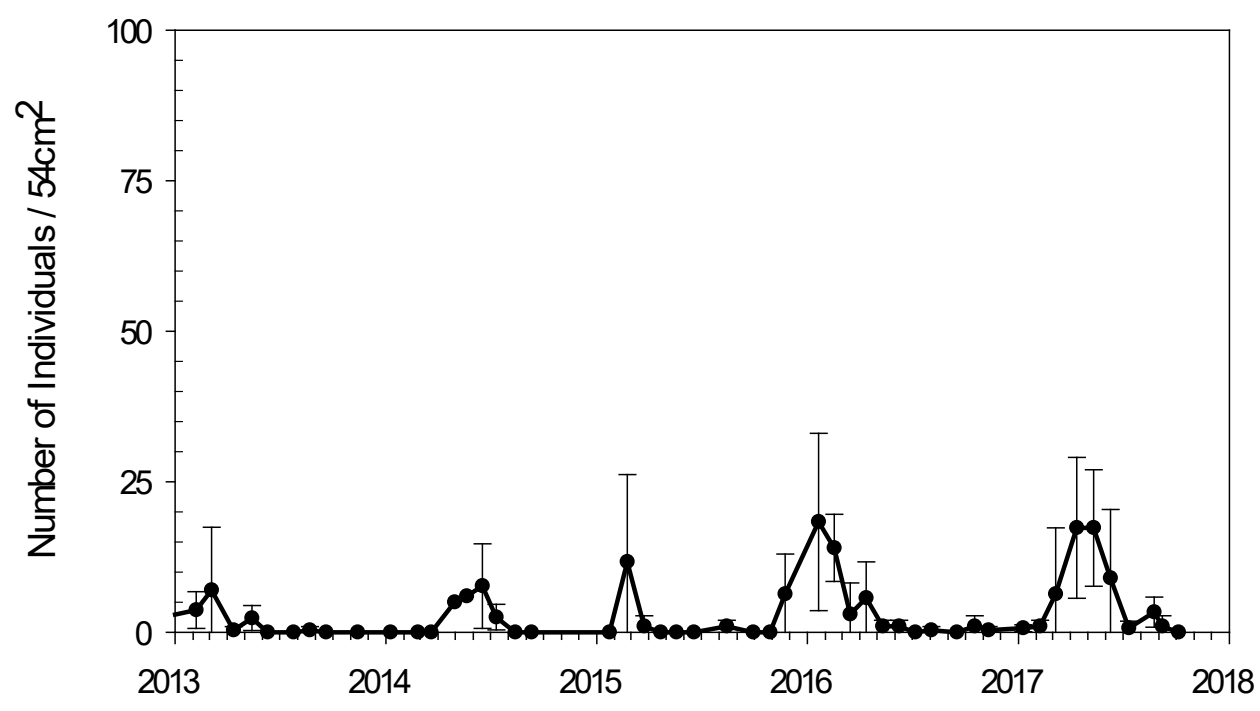

Figure 25. Monthly average abundance of Streblospio benedicti, Palo Alto, Calif., (A) 1974-2017 and (B) 20132017. Error bars represent standard deviation from three replicate samplings. Collections were not made between 1991 and 1998. Cm, centimeters. 
A.

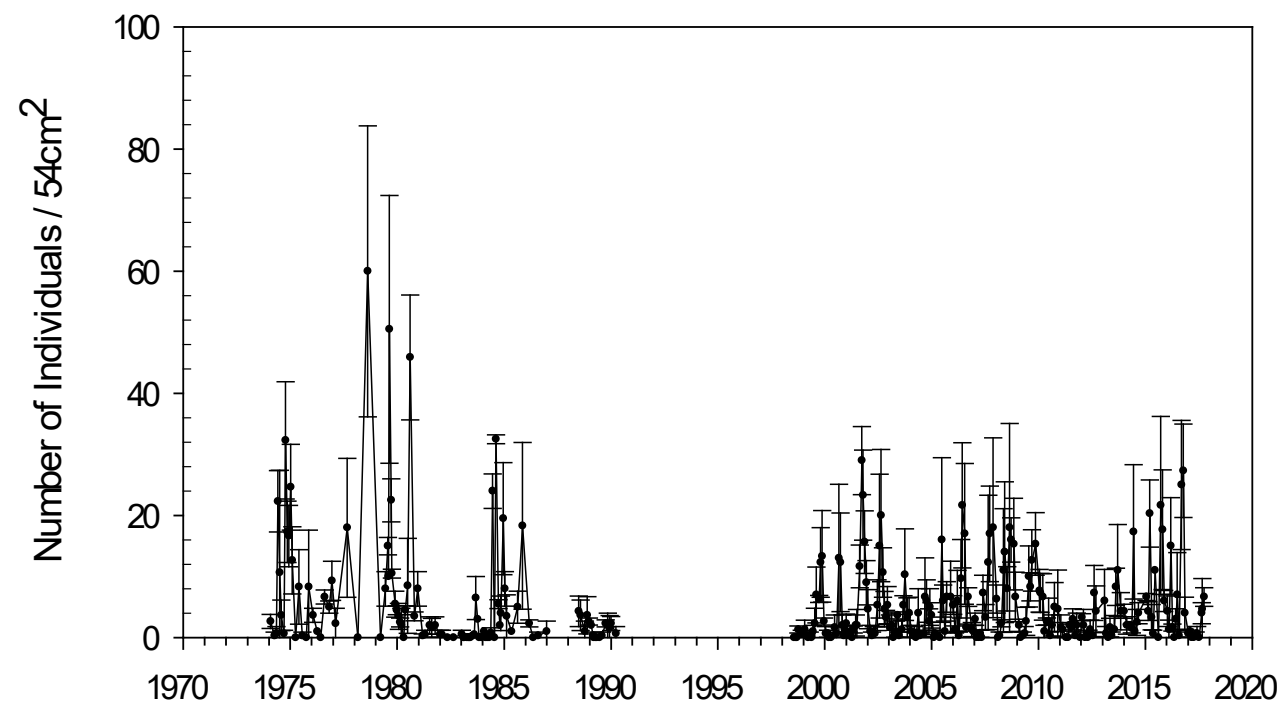

B.

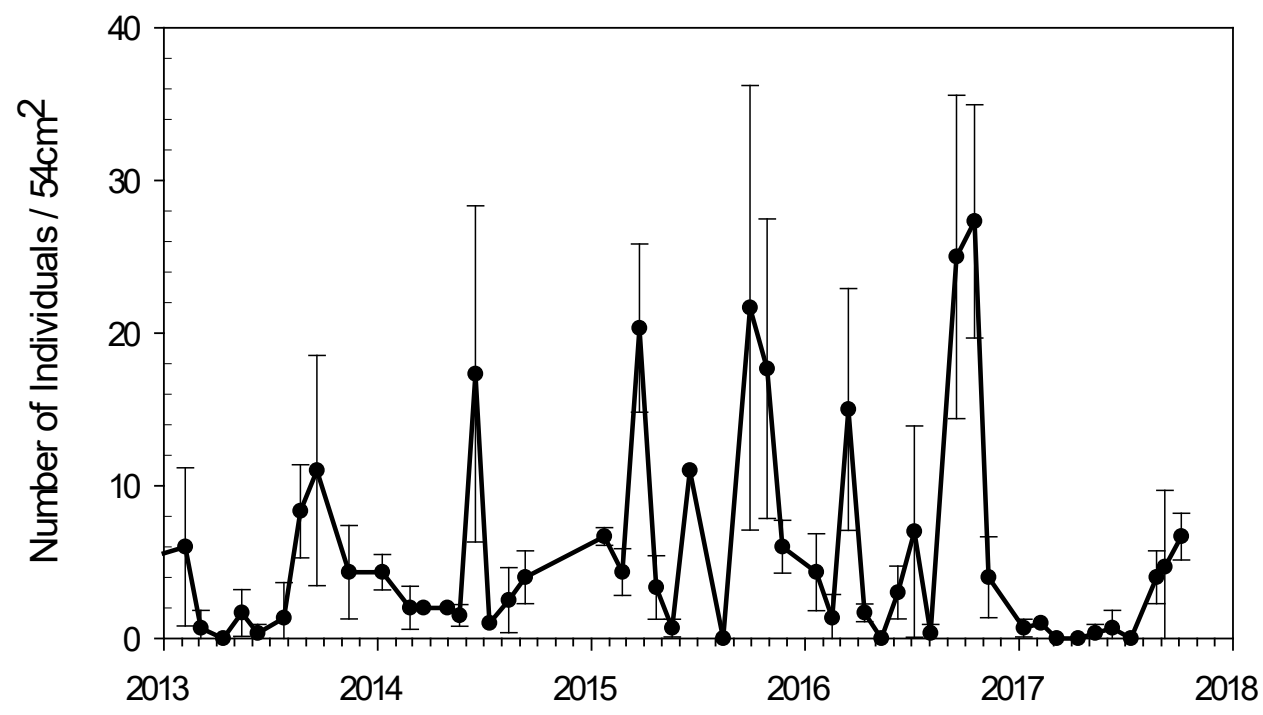

Figure 26. Monthly average abundance of Grandiderella japonica, Palo Alto, Calif., $(A)$ 1974-2017 and (B) 20132017. Error bars represent standard deviation from three replicate samplings. Collections were not made between 1991 and 1998. Cm, centimeters. 
A.

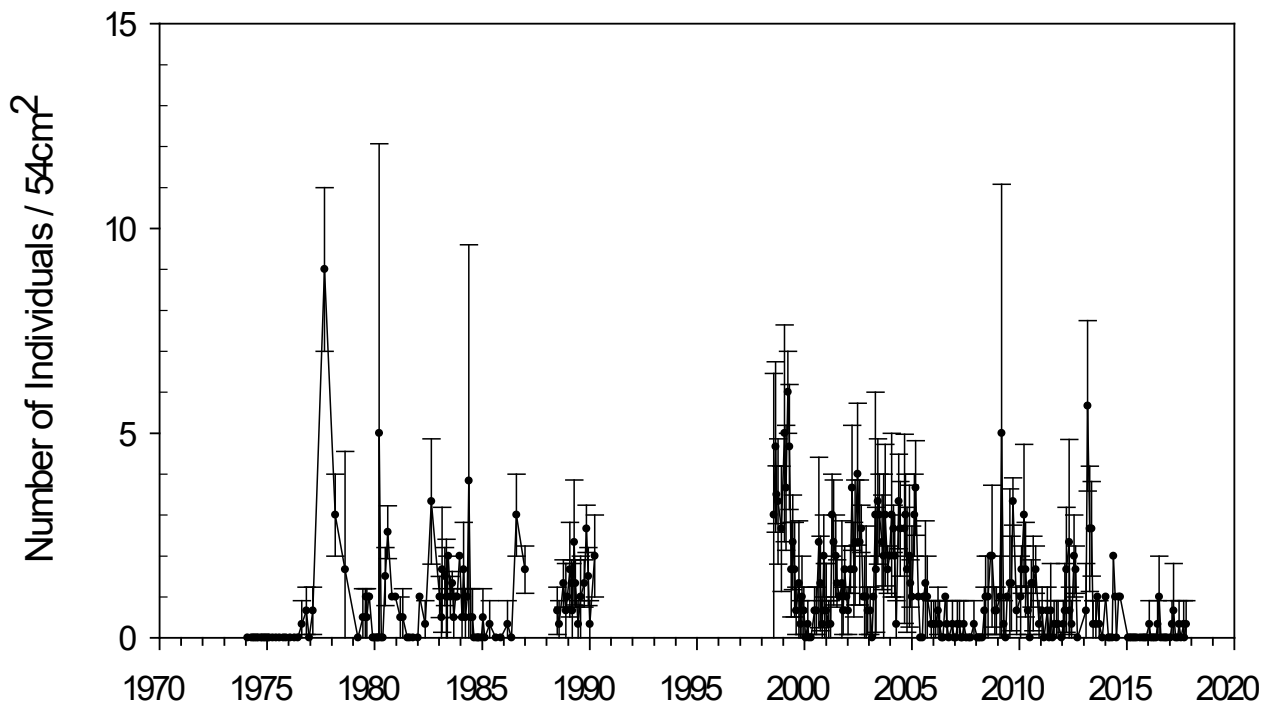

B.

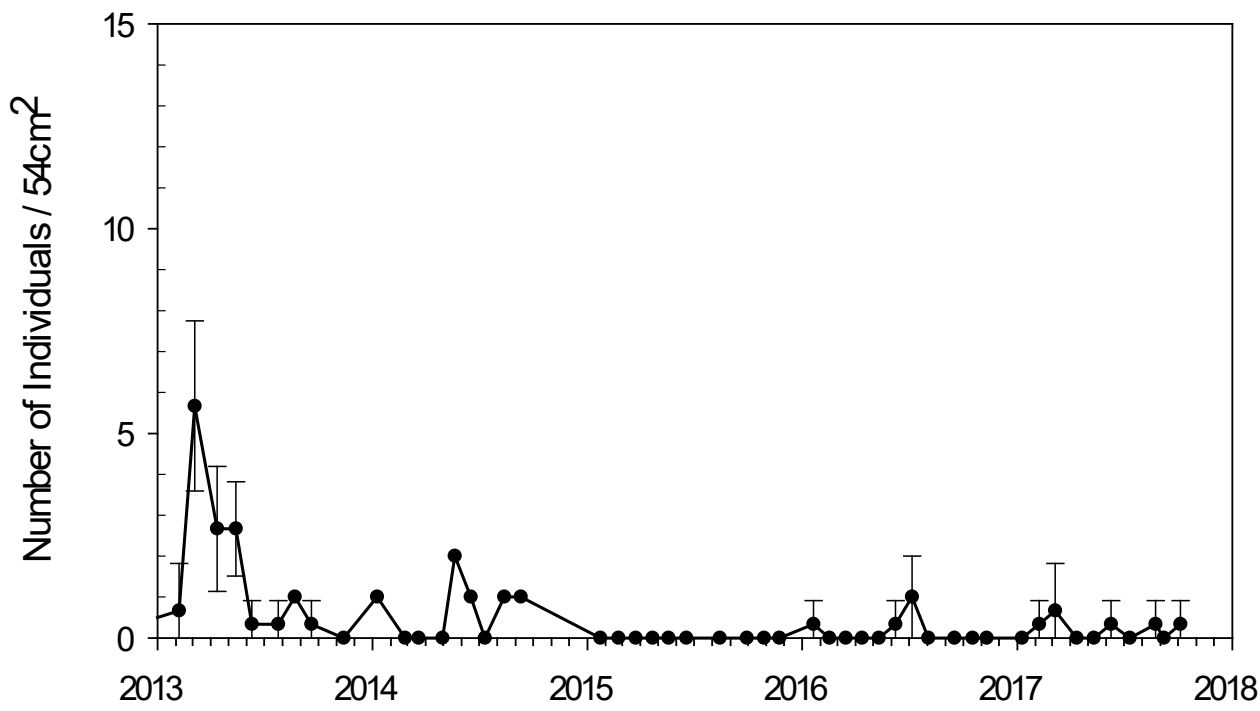

Figure 27. Monthly average abundance of Atilla succinea, Palo Alto, Calif., (A) 1974-2017 and (B) 2013-2017. Error bars represent standard deviation from three replicate samplings. Collections were not made between 1991 and 1998. Cm, centimeters. 
A.

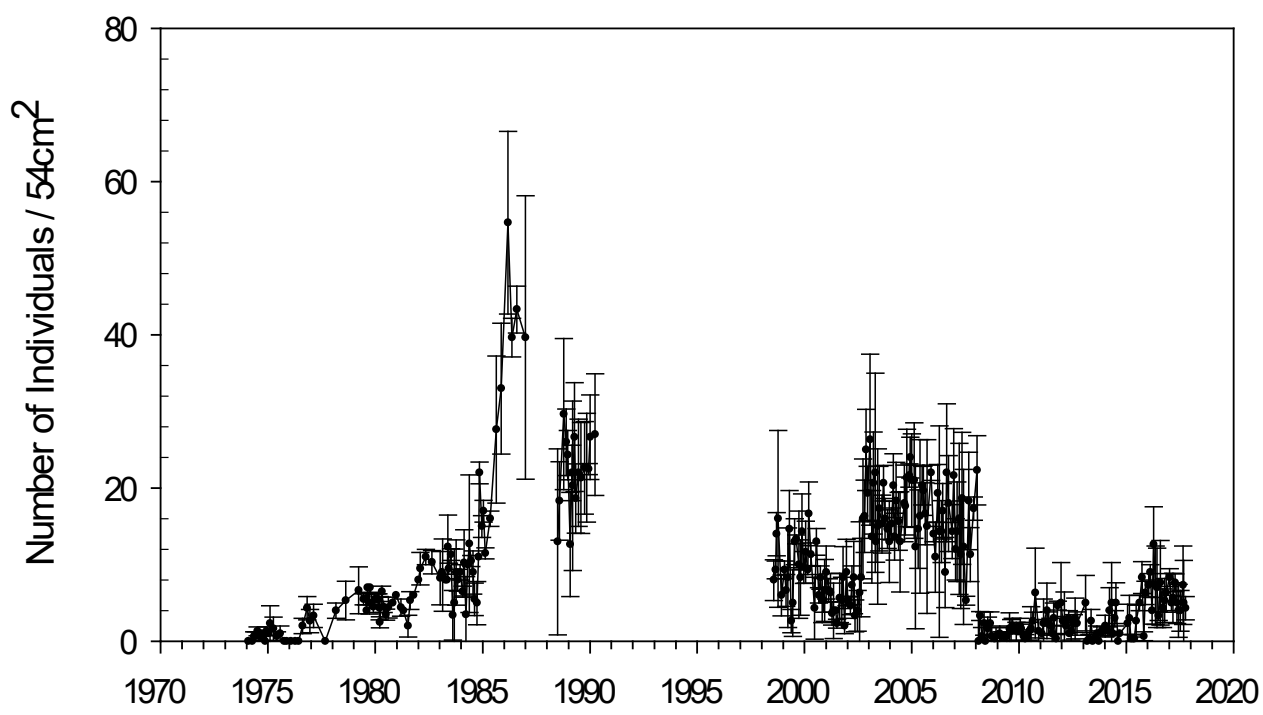

B.

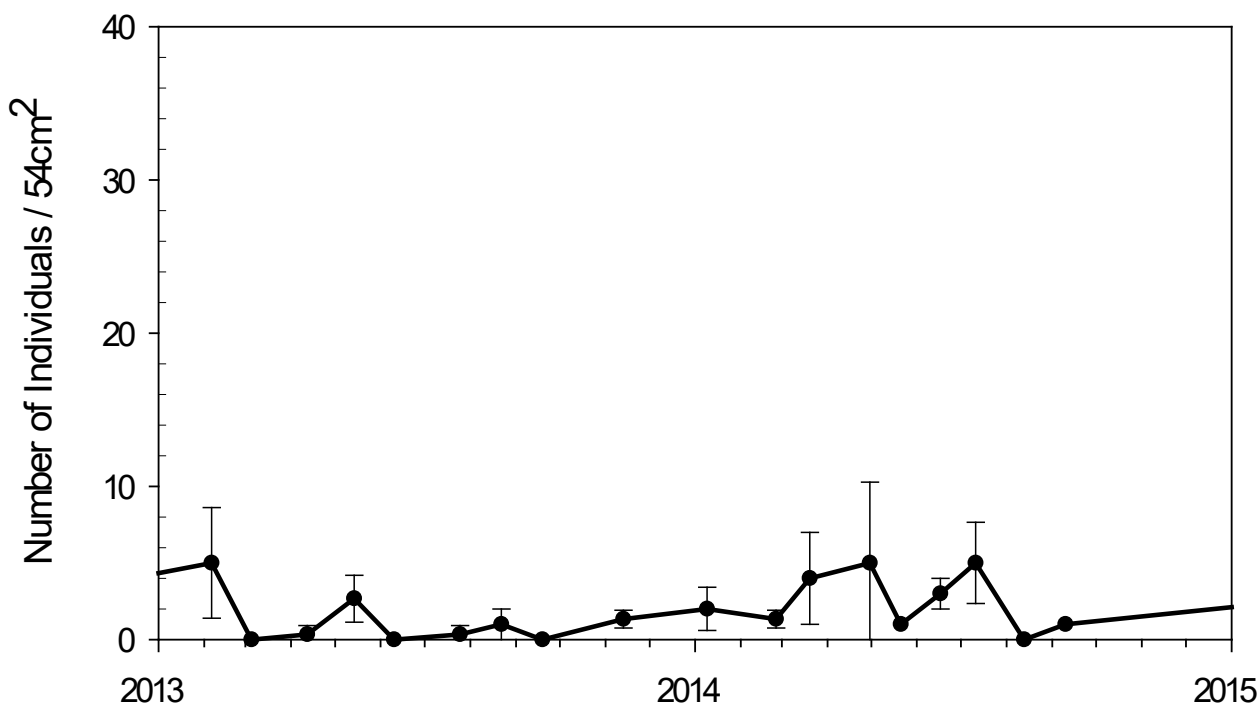

Figure 28. Monthly average abundance of Heteromastus filiformis, Palo Alto, Calif., (A) 1974-2017 and (B) 20132015. Error bars represent standard deviation from three replicate samplings. Collections were not made between 1991 and 1998. Cm, centimeters. 
A.

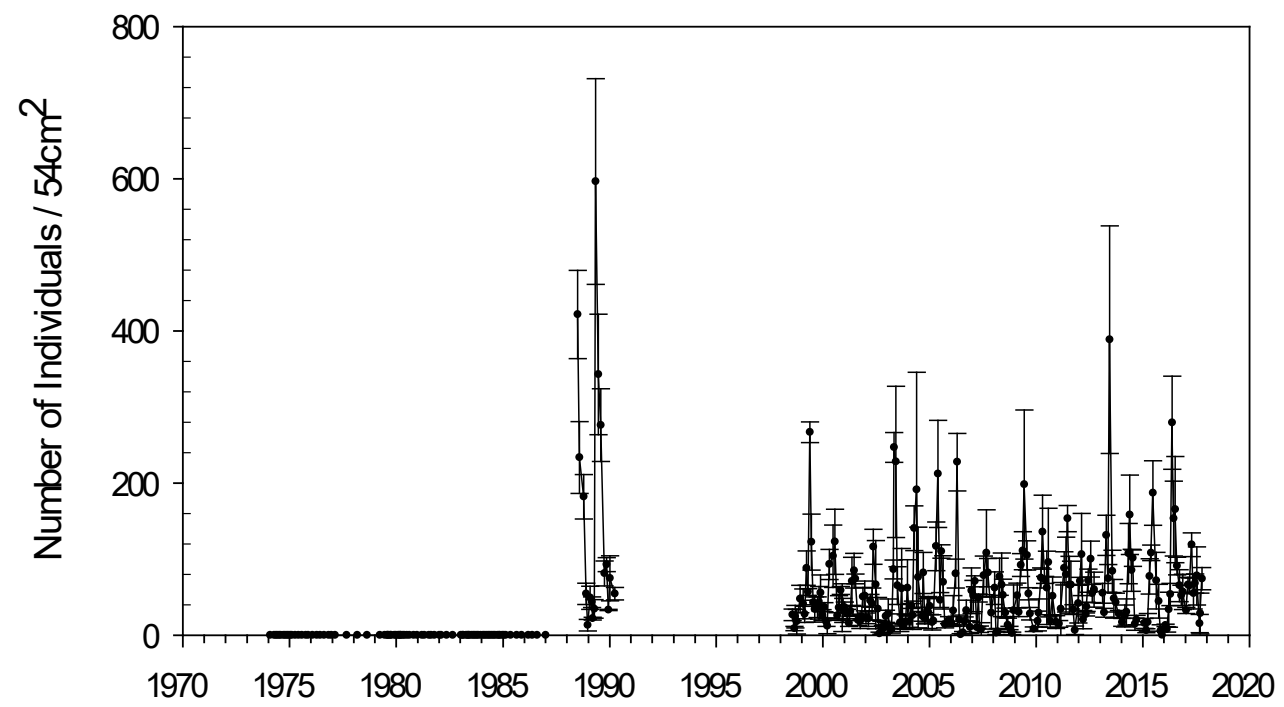

B.

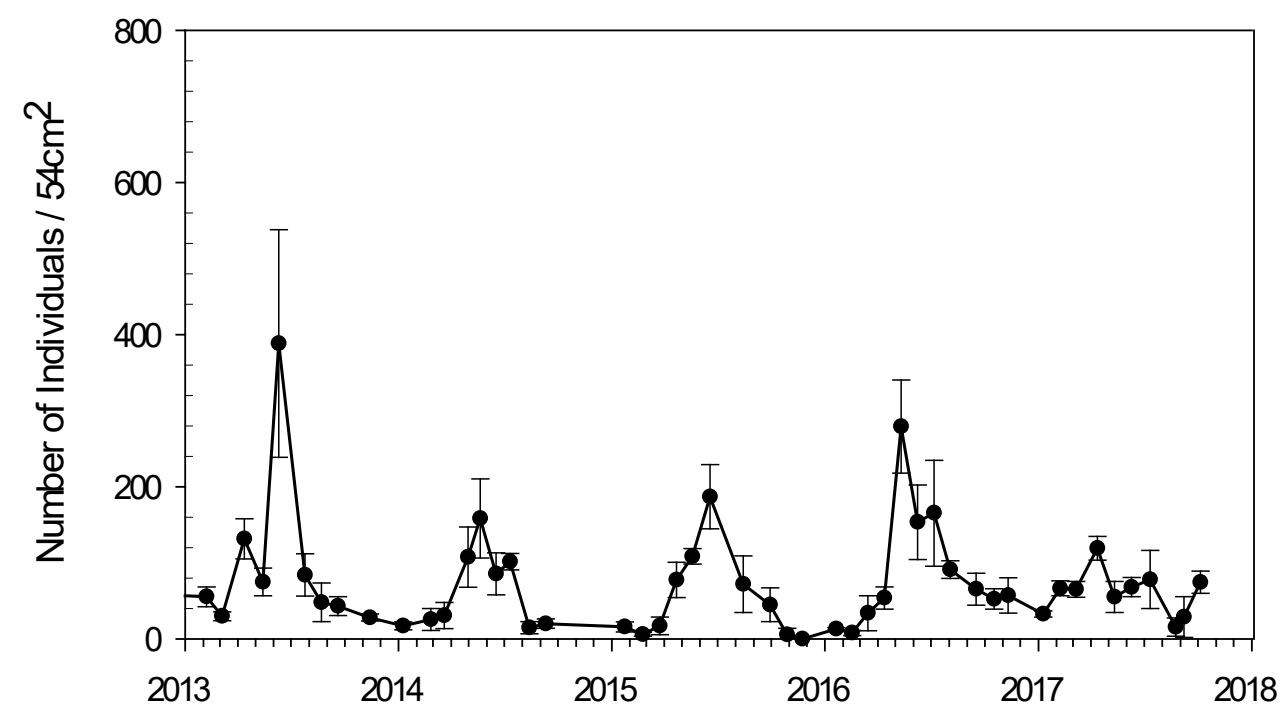

Figure 29. Monthly average abundance of Nippoleucon hinumensis, Palo Alto, Calif., (A) 1974-2017 and (B) 2013-2017. Error bars represent standard deviation from three replicate samplings. Collections were not made between 1991 and 1998. Cm, centimeters. 


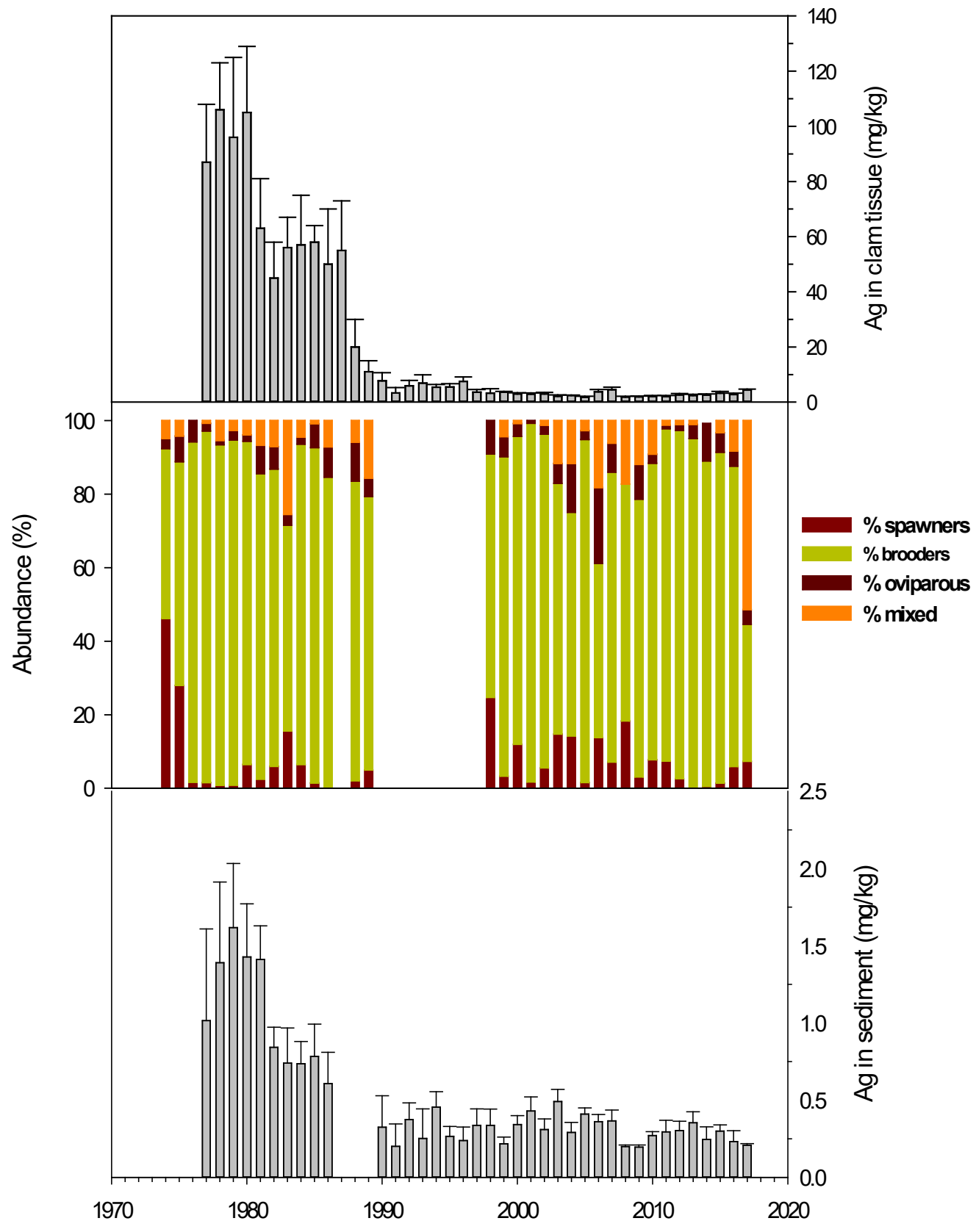

Figure 30. Reproductive mode annual abundance with silver (Ag) concentrations (grand mean $\pm \mathrm{SEM}$ ), in milligrams per kilogram (mg/kg), in the clam Macoma petalum and in sediment, Palo Alto, Calif., 1974-2017. Annual abundance data (in percent) is from August of each year. The reproductive mode of the top 10 ranked species for each year is shown: brooder, broods young and release juveniles as fully functional "miniature adults"; oviparous, lays eggs in or on sediment; spawner, releases gametes into water column and juveniles settle out of plankton onto sediment surface after growth in the plankton. 


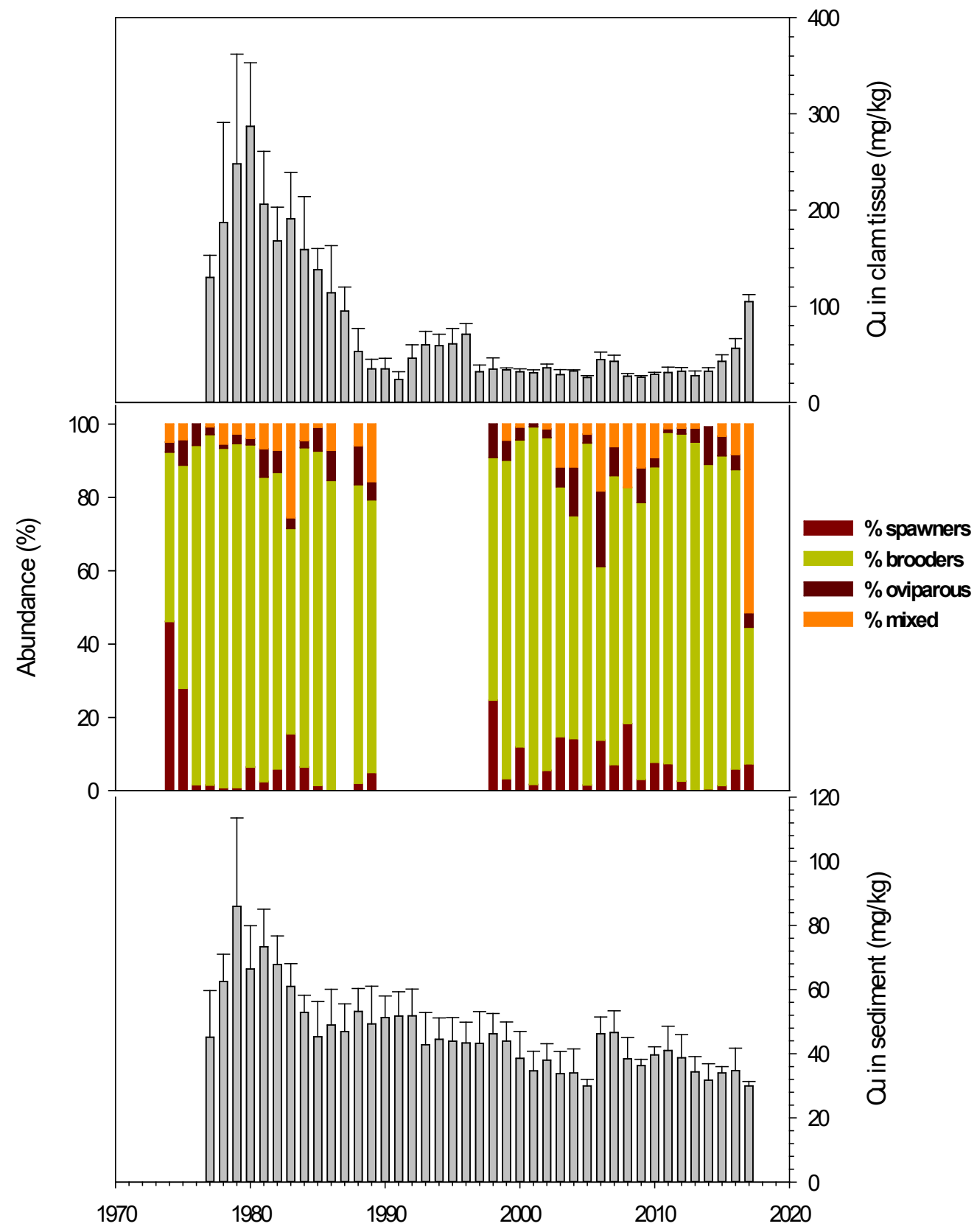

Figure 31. Reproductive mode annual abundance with copper ( $\mathrm{Cu}$ ) concentrations (grand mean $\pm \mathrm{SEM}$ ), in milligrams per kilogram (mg/kg), in the clam Macoma petalum and in sediment, Palo Alto, Calif., 1974-2017. Annual abundance data (in percent) is from August of each year. The reproductive mode of the top 10 ranked species for each year is shown: brooder, broods young and release juveniles as fully functional "miniature adults"; oviparous, lays eggs in or on sediment; spawner, releases gametes into water column and juveniles settle out of plankton onto sediment surface after growth in the plankton. 


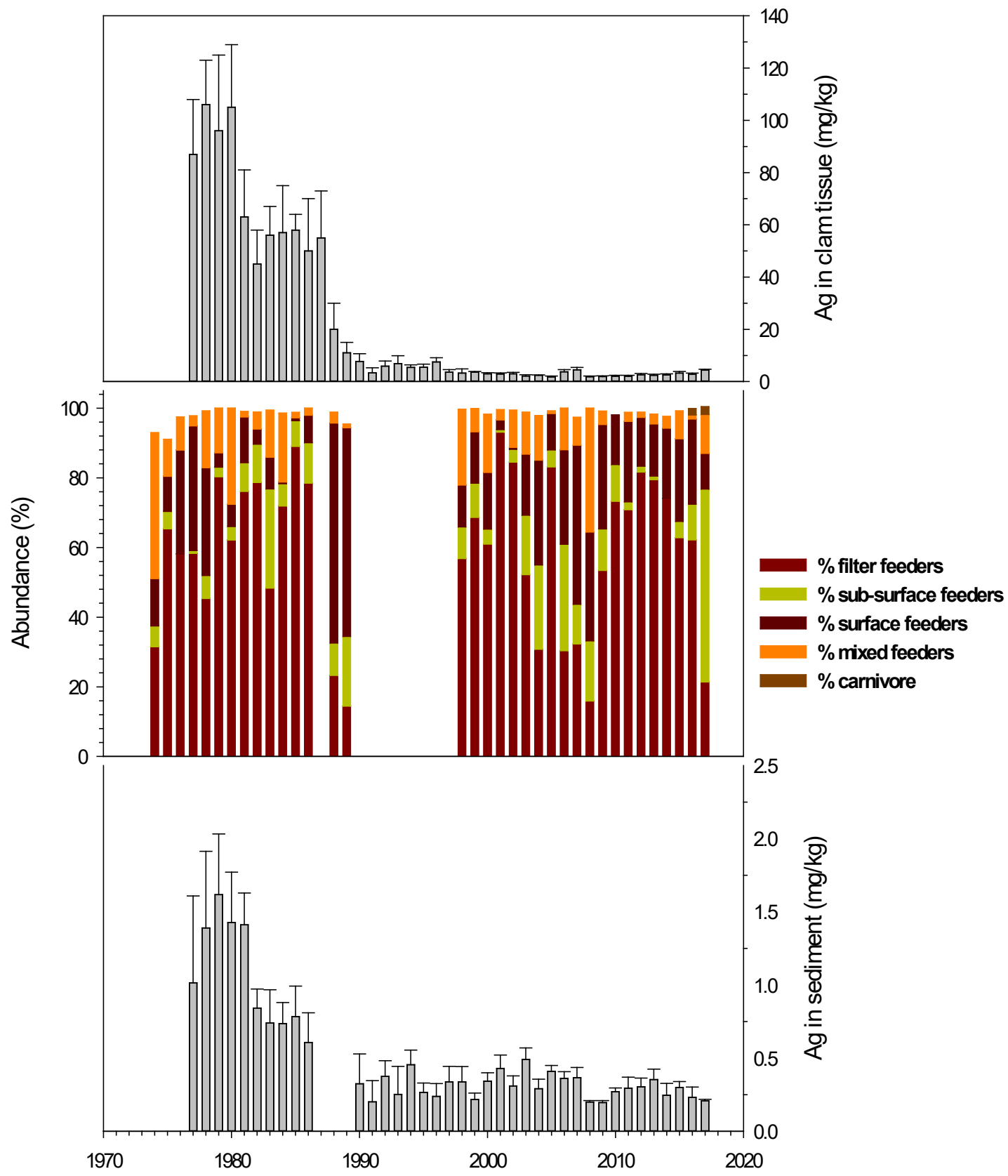

Figure 32. Feeding mode annual abundance with silver (Ag) concentrations, in milligrams per kilogram ( $\mathrm{mg} / \mathrm{kg})$, in the clam Macoma petalum and in sediment, Palo Alto, Calif., 1974-2017. Annual abundance data (in percent) is from August of each year. The feeding mode of the top 10 ranked species for each year is shown: filter, filters food particles from water column; subsurface deposit, ingests subsurface sediment and removes food from sediment in gut; surface deposit, ingests food particles on surface sediment; mixed, capable of filter feeding and surface deposit feeding; carnivore, preys on other infaunal invertebrates. 


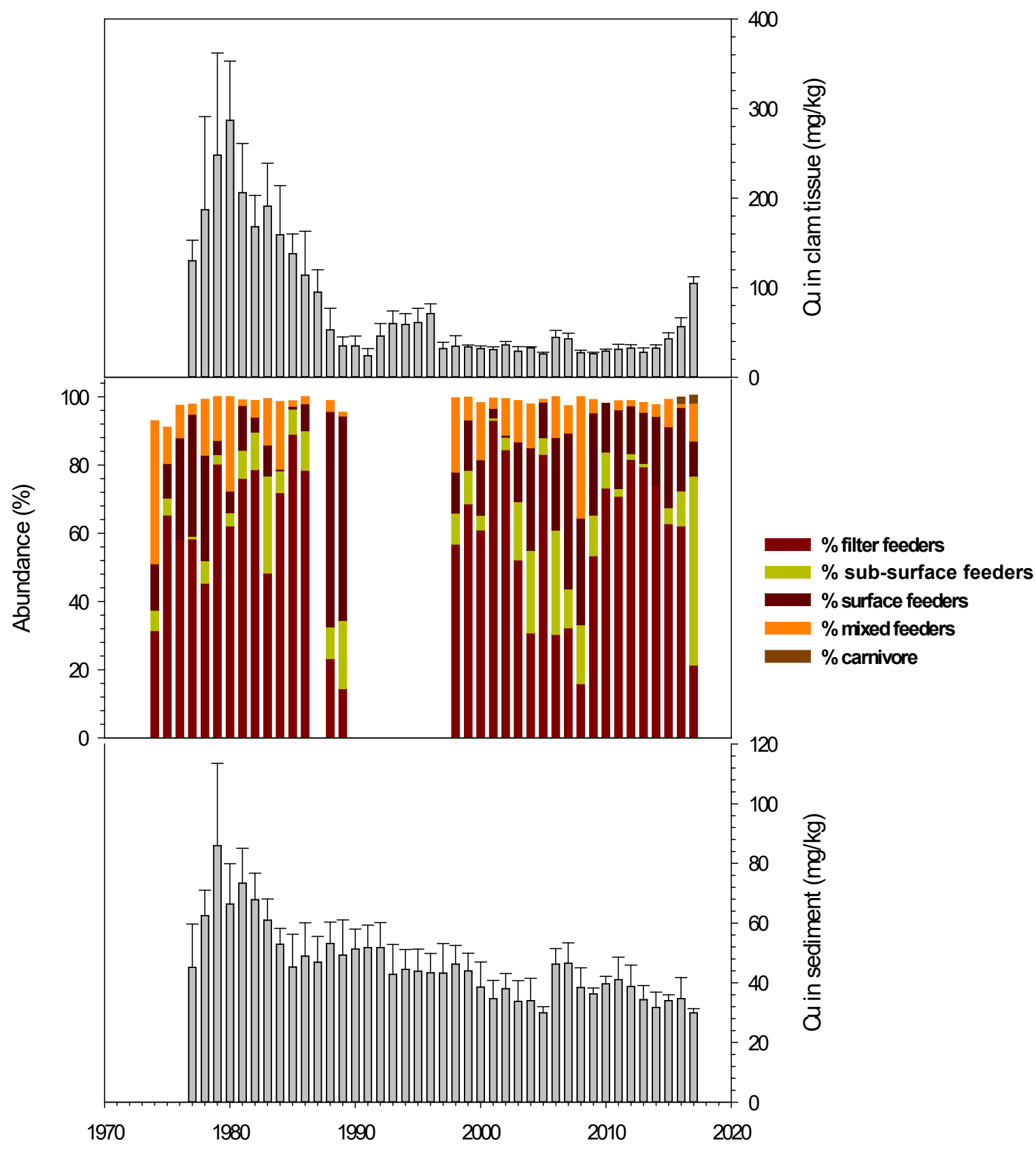

Figure 33. Feeding mode annual abundance with copper $(\mathrm{Cu})$ concentrations in the clam Macoma petalum and in sediment, Palo Alto, Calif., 1974-2017. Annual abundance data (in percent) is from August of each year. The feeding mode of the top 10 ranked species for each year is shown: filter, filters food particles from water column; subsurface deposit, ingests subsurface sediment and removes food from sediment in gut; surface deposit, ingests food particles on surface sediment; mixed, capable of filter feeding and surface deposit feeding; carnivore, preys on other infaunal invertebrates. 


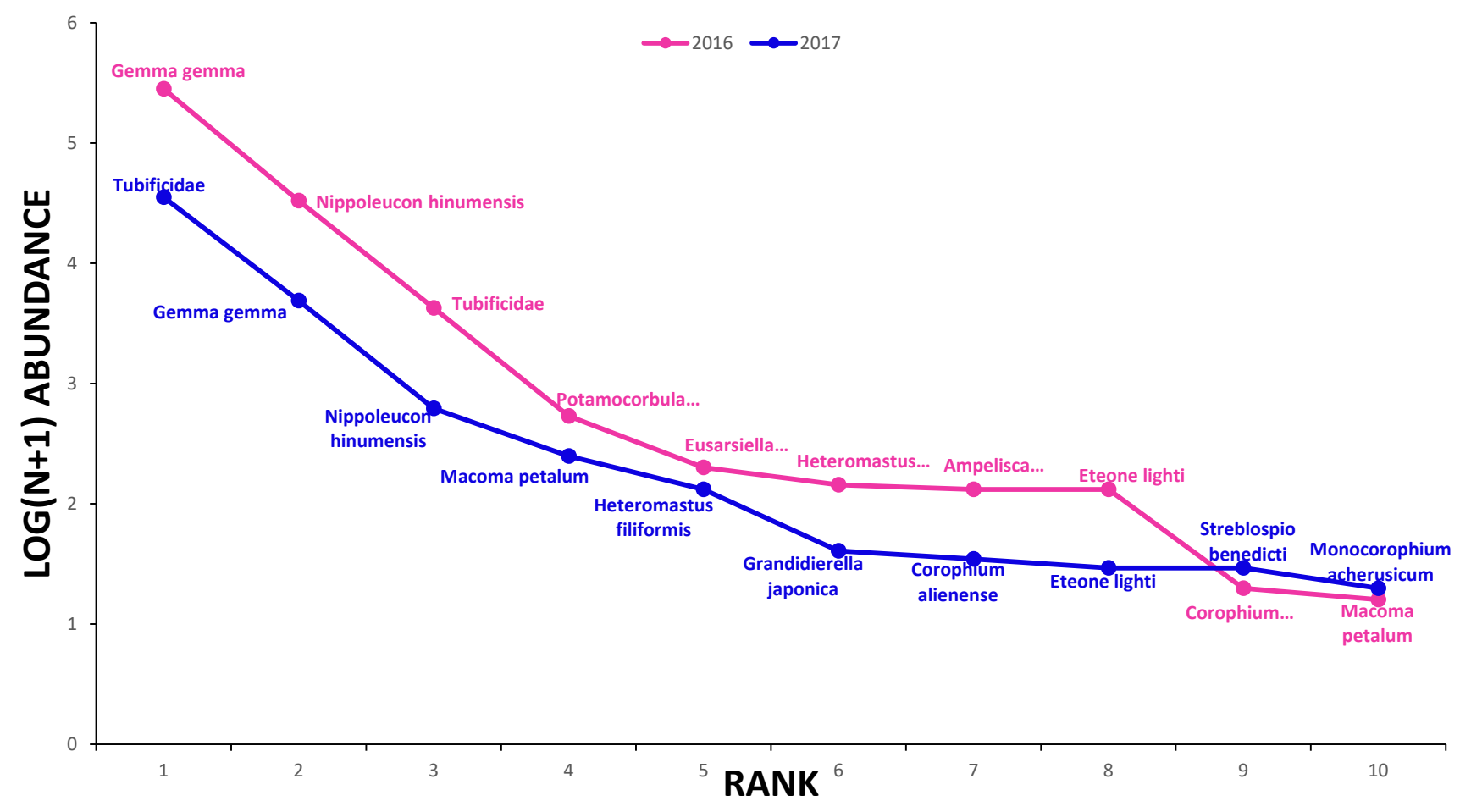

Figure 34. Species rank-abundance for the benthic community, Palo Alto, Calif., for 2016 and 2017. 


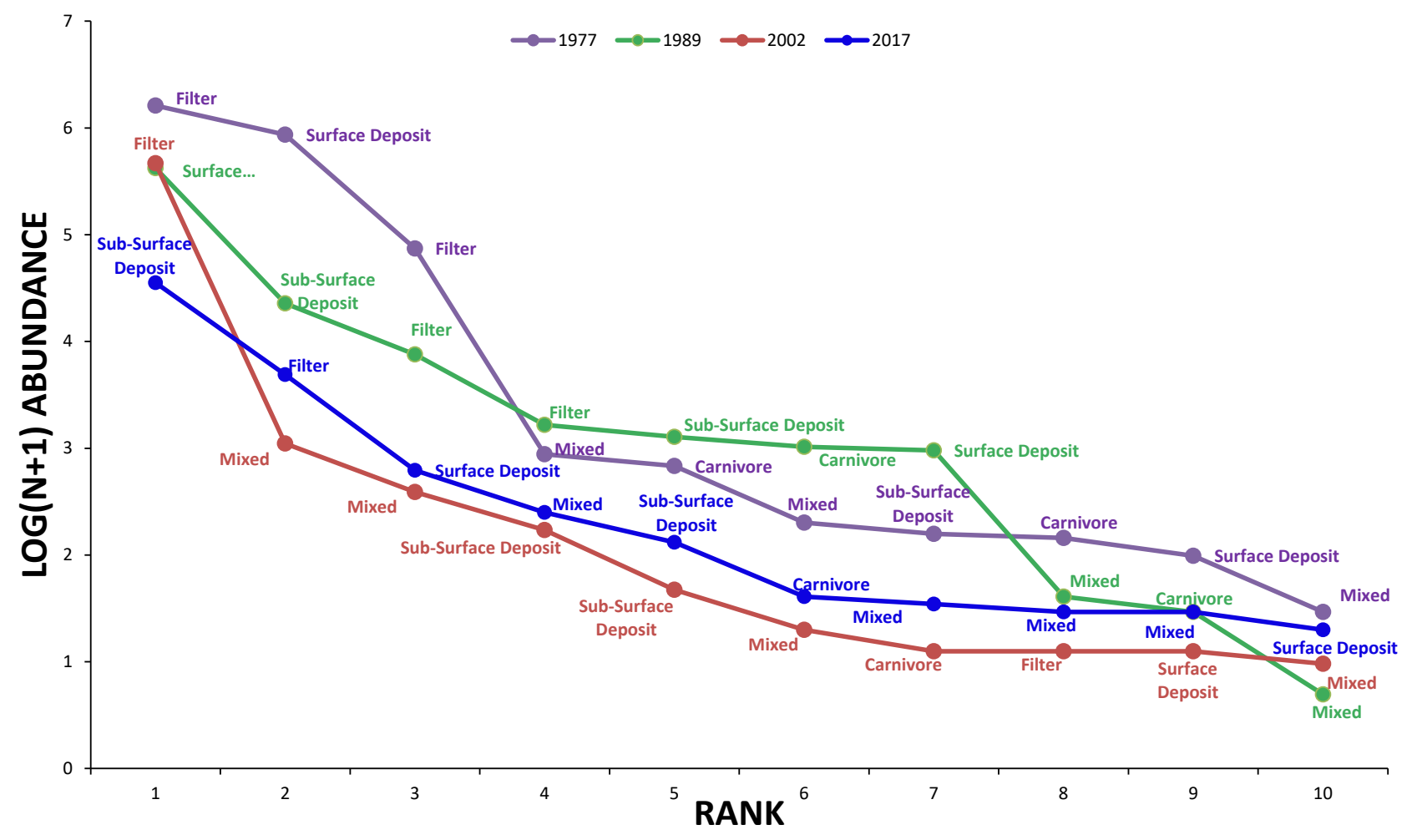

Figure 35. Species rank-abundance identified by feeding mode, Palo Alto, Calif., for 1977, 1989, 2002, and 2017. The feeding mode for each species at each rank is shown: filter, filters food particles from water column; subsurface deposit, ingests subsurface sediment and removes food from sediment in gut; surface deposit, ingests food particles on surface sediment; mixed, capable of filter feeding and surface deposit feeding; carnivore, predator on other fauna. 


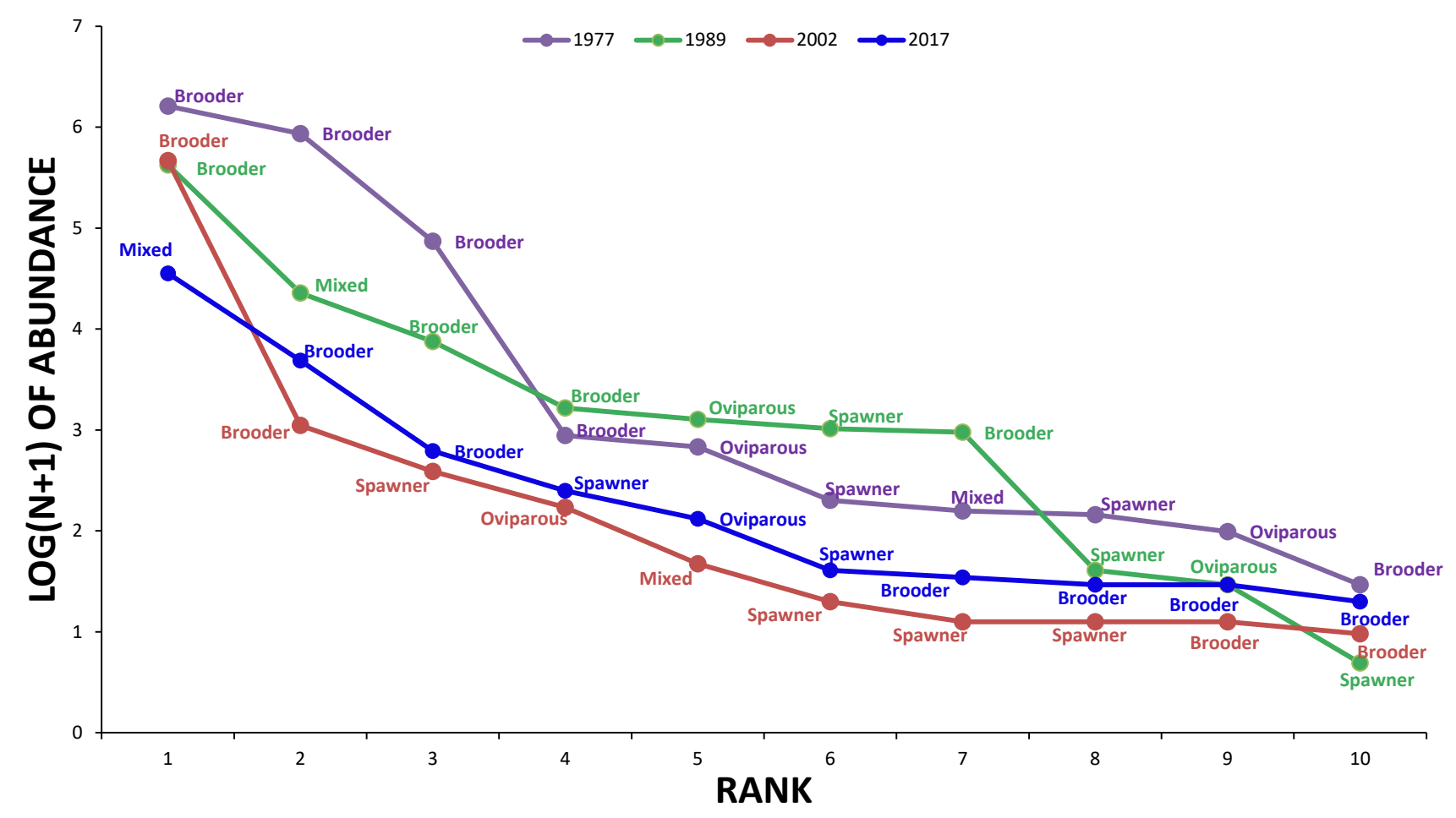

Figure 36. Species rank-abundance data identified by reproductive mode, Palo Alto, Calif., for 1977, 1989, 2002, and 2017. Reproductive mode for each species at each rank is shown: brooder, broods young and release juveniles as fully functional "miniature adults"; oviparous, lays eggs in or on sediment; spawner, releases gametes into water column and juveniles settle out of plankton onto sediment surface after growth in the plankton. 
Table 1. Concentrations of fine particles in surface sediments and major and minor inorganic elements for samples collected from Palo Alto, Calif., 2017. [Units for aluminum (Al), iron (Fe), and fine sediment are percent of dry weight. Fine sediment is operationally determined as $\leq 100$ micrometer grain size. Elemental concentrations for the monthly samples are reported as the mean \pm 1 standard deviation (std) for replicate subsamples $(\mathrm{n}=2)$, except mercury (Hg) and selenium (Se) which are single measurements $(\mathrm{n}=1)$. Units are milligram per kilogram dry weight. Means for monthly samples were summarized and reported as the annual mean \pm the standard error (SEM) ( $\mathrm{n}=6$ or 9). All concentrations are based on near-total extracts, except for silver (Ag), which is based on partial extraction (see text section in Methods). ND, no data.

\begin{tabular}{|c|c|c|c|c|c|c|c|c|c|c|c|c|c|c|c|c|c|c|c|c|c|c|c|c|}
\hline Date & $\begin{array}{c}\text { Fine } \\
\text { sediment } \\
(\%)\end{array}$ & & $\mathrm{Ag}$ & & & ( $(\%)$ & & & $\mathrm{Cr}$ & & & $\mathrm{Cu}$ & & & e (\%) & & $\mathrm{Hg}$ & & $\mathrm{Ni}$ & & Se & & $\mathrm{Zn}$ & \\
\hline $1 / 20 / 2017$ & 47 & 0.21 & \pm & 0.003 & 3.9 & \pm & 0.2 & 108 & \pm & 4 & 28.6 & \pm & 0.5 & 3.8 & \pm & 0.1 & 0.28 & 76 & \pm & 0.1 & 0.52 & 107 & \pm & 0.9 \\
\hline $2 / 16 / 2017$ & 67 & 0.23 & \pm & 0.002 & 4.2 & \pm & 0.3 & 110 & \pm & 4 & 31.0 & \pm & 2.2 & 4.2 & \pm & 0.0 & 0.27 & 89 & \pm & 0.2 & 0.50 & 119 & \pm & 0.3 \\
\hline $3 / 14 / 2017$ & 66 & 0.18 & \pm & 0.002 & 3.9 & \pm & 0.4 & 103 & \pm & 6 & 28.9 & \pm & 0.9 & 3.7 & \pm & 0.2 & ND & 77 & \pm & 2.3 & ND & 102 & \pm & 3.8 \\
\hline $4 / 12 / 2017$ & 63 & 0.25 & \pm & 0.001 & 4.4 & \pm & 0.5 & 102 & \pm & 19 & 35.0 & \pm & 2.2 & 4.3 & \pm & 0.2 & 0.30 & 88 & \pm & 0.9 & 0.52 & 124 & \pm & 2.5 \\
\hline $5 / 10 / 2017$ & 45 & 0.19 & \pm & 0.003 & 4.4 & \pm & 0.1 & 118 & \pm & 0 & 33.2 & \pm & 1.2 & 4.2 & \pm & 0.0 & ND & 88 & \pm & 0.1 & ND & 118 & \pm & 0.0 \\
\hline $6 / 12 / 2017$ & 31 & 0.17 & \pm & 0.003 & 3.3 & \pm & 0.0 & 98 & \pm & 1 & 22.7 & \pm & 0.2 & 3.5 & \pm & 0.0 & 0.22 & 71 & \pm & 0.3 & 0.36 & 94 & \pm & 1.0 \\
\hline 9/6/2017 & 35 & 0.18 & \pm & 0.006 & 3.6 & \pm & 0.3 & 110 & \pm & 12 & 31.4 & \pm & 0.5 & 3.6 & \pm & 0.0 & 0.29 & 79 & \pm & 0.4 & 0.40 & 109 & \pm & 0.8 \\
\hline $10 / 18 / 2017$ & 44 & 0.25 & \pm & 0.004 & 7.4 & \pm & 0.1 & 214 & \pm & 4 & 24.7 & \pm & 0.1 & 7.5 & \pm & 0.2 & ND & 159 & \pm & 3.5 & ND & 109 & \pm & 2.3 \\
\hline $12 / 11 / 2017$ & 76 & 0.21 & \pm & 0.001 & 4.9 & \pm & 0.1 & 118 & \pm & 5 & 34.2 & \pm & 0.3 & 4.3 & \pm & 0.0 & 0.35 & 97 & \pm & 0.2 & 0.48 & 127 & \pm & 0.1 \\
\hline Annual Mean: & 53 & & 0.21 & & & 4.4 & & & 120 & & & 30 & & & 4.3 & & 0.29 & & 92 & & 0.46 & & 112 & \\
\hline SEM: & 5 & & 0.01 & & & 0.4 & & & 12 & & & 1 & & & 0.4 & & 0.02 & & 9 & & 0.03 & & 4 & \\
\hline
\end{tabular}


Table 2. Concentrations of trace metals and the condition index of the clam Macoma petalum, Palo Alto, Calif., 2017.

[Monthly data are the mean and standard deviation for replicate composites $(\mathrm{n}=8-11, \mathrm{n}=2-3$ for selenium [Se] and mercury [Hg]). Means for monthly samples were summarized and reported as the annual mean \pm the standard error (SEM) ( $\mathrm{n}=6$ or 9$)$. All concentrations are based on near-total extracts. Elemental concentrations are milligram per kilogram soft tissue dry weight. The condition index (CI) is the soft tissue weight in milligrams of a clam of 25 -millimeter shell length. ND, no data]

\begin{tabular}{|c|c|c|c|c|c|c|c|c|c|c|c|c|c|c|c|c|c|c|c|c|c|c|}
\hline Date & & $\mathrm{Ag}$ & & & $\mathrm{Cr}$ & & & u & & & $\mathrm{Hg}$ & & & $\mathrm{Ni}$ & & & $\mathrm{Se}$ & & & $\mathrm{Zn}$ & & $\begin{array}{c}\text { Condition } \\
\text { index }\end{array}$ \\
\hline $1 / 20 / 2017$ & 3.4 & \pm & 0.3 & 3.41 & \pm & 0.45 & 60 & \pm & 8 & 0.42 & \pm & 0.05 & 5.6 & \pm & 0.4 & 4.56 & \pm & 0.60 & 272 & \pm & 29 & 73 \\
\hline $2 / 16 / 2017$ & 4.1 & \pm & 0.5 & 5.16 & \pm & 0.03 & 100 & \pm & 25 & 0.48 & \pm & 0.05 & 6.9 & \pm & 0.5 & 4.84 & \pm & 0.30 & 337 & \pm & 27 & 64 \\
\hline $3 / 14 / 2017$ & 5.4 & \pm & 1.0 & 4.74 & \pm & 0.41 & 124 & \pm & 20 & & ND & & 7.6 & \pm & 0.7 & & ND & & 511 & \pm & 41 & 68 \\
\hline $4 / 12 / 2017$ & 3.8 & \pm & 0.2 & 2.52 & \pm & 0.19 & 120 & \pm & 9 & 0.59 & \pm & 0.16 & 4.6 & \pm & 0.2 & 4.88 & \pm & 0.10 & 305 & \pm & 11 & 108 \\
\hline $5 / 10 / 2017$ & 3.4 & \pm & 0.5 & 1.58 & \pm & 0.11 & 100 & \pm & 20 & & ND & & 4.1 & \pm & 0.1 & & ND & & 335 & \pm & 18 & 108 \\
\hline $6 / 12 / 2017$ & 3.2 & \pm & 0.2 & 1.65 & \pm & 0.06 & 78 & \pm & 12 & 0.51 & \pm & 0.09 & 4.7 & \pm & 0.1 & 4.82 & \pm & 0.30 & 357 & \pm & 27 & 105 \\
\hline $10 / 18 / 2017$ & 4.9 & \pm & 0.5 & 4.61 & \pm & 0.36 & 124 & \pm & 0 & & ND & & 6.0 & \pm & 0.2 & & ND & & 331 & \pm & 21 & 89 \\
\hline $12 / 11 / 2017$ & 5.3 & \pm & 1.1 & 3.70 & \pm & 0.59 & 117 & \pm & 44 & 0.70 & \pm & 0.17 & 5.6 & \pm & 0.9 & 5.56 & \pm & 0.20 & 326 & \pm & 53 & 262 \\
\hline Annual mean: & & 4.37 & & & 3.31 & & & 05 & & & 0.57 & & & 5.64 & & & 4.96 & & & 346 & & 107 \\
\hline SEM: & & 0.34 & & & 0.45 & & & 8 & & & 0.05 & & & 0.37 & & & 0.14 & & & 22 & & 20 \\
\hline
\end{tabular}




\section{Appendix 1. Certified concentrations and the percent recoveries of inorganic elements in National Institute of Science and Technology (NIST) Standard Reference Material 2709a (San Joaquin Soil) and 2711a (Montana Soil) prepared in 2017.}

[mg/kg, milligrams per kilogram; \%, percent; CI, 95\% confidence interval; N, sample size]

\begin{tabular}{|c|c|c|c|c|c|c|}
\hline \multirow{2}{*}{$\begin{array}{c}\text { Reference } \\
\text { material }\end{array}$} & \multirow{2}{*}{$\begin{array}{l}\text { Constituent } \\
\text { Aluminum }\end{array}$} & \multirow{2}{*}{$\begin{array}{l}\mathbf{N} \\
18\end{array}$} & \multirow{2}{*}{$\begin{array}{c}\begin{array}{c}\text { Certified } \\
\text { value } \\
\text { (mg/kg) }\end{array} \\
73,700\end{array}$} & \multicolumn{3}{|c|}{$\begin{array}{l}\text { Recovery mean } \\
\quad \pm \mathrm{Cl}(\%)\end{array}$} \\
\hline & & & & 49 & \pm & 1 \\
\hline & Chromium & 18 & 130 & 65 & \pm & 3 \\
\hline & Copper & 18 & 33.9 & 67 & \pm & 1 \\
\hline & Iron & 18 & 33,600 & 93 & \pm & 1 \\
\hline & Nickel & 18 & 85 & & \pm & 1 \\
\hline & Sliver & & & \multicolumn{3}{|c|}{ unknown } \\
\hline & Zinc & 18 & 103 & 71 & \pm & 1 \\
\hline \multirow[t]{7}{*}{$2711 \mathrm{a}$} & Aluminum & 18 & 67,200 & 41 & \pm & 1 \\
\hline & Chromium & 18 & 52.3 & 52 & \pm & 2 \\
\hline & Copper & 18 & 140 & 82 & \pm & 1 \\
\hline & Iron & 18 & 28,200 & 86 & \pm & 1 \\
\hline & Nickel & 18 & 21.7 & 62 & \pm & 1 \\
\hline & Sliver & 18 & 6 & 89 & \pm & 3 \\
\hline & Zinc & 18 & 414 & 94 & \pm & 1 \\
\hline
\end{tabular}




\section{Appendix 2. Certified concentrations and the percent recoveries of inorganic elements in National Institute of Science and Technology Standard Reference Material 2976 (Mussel Tissue) and 1566b (Oyster Tissue) prepared in 2017.}

[Samples were not diluted prior to analysis. \%, percent, mg/kg, milligrams per kilogram; CI, 95\% confidence interval; N, sample size]

\begin{tabular}{ccccccc}
\hline $\begin{array}{c}\text { Reference } \\
\text { material }\end{array}$ & Constituent & $\mathbf{N}$ & $\begin{array}{c}\text { Certified } \\
\text { value } \\
(\mathbf{m g} / \mathbf{k g})\end{array}$ & $\begin{array}{c}\text { Recovery mean } \\
\mathbf{\pm C l}(\%)\end{array}$ \\
\hline Tort-3 & Chromium & 18 & 1.95 & 83 & \pm & 3 \\
& Copper & 18 & 497 & 84 & \pm & 3 \\
& Nickel & 18 & 5.3 & 81 & \pm & 3 \\
& Silver & & unknown & & & \\
& Zinc & 18 & 136 & 107 & \pm & 2 \\
$1566 \mathrm{~b}$ & & & & & & \\
& Chromium & & unknown & & & \\
& Copper & 18 & 71.6 & 94 & \pm & 3 \\
& Nickel & 18 & 1.04 & 91 & \pm & 2 \\
& Silver & 18 & 0.666 & 92 & \pm & 5 \\
& Zinc & 18 & 1424 & 110 & \pm & 3 \\
\hline
\end{tabular}

\section{Appendix 3. Mercury $(\mathrm{Hg})$ and selenium (Se) concentrations determined in sample splits of surface sediments and Macoma petalum collected at Palo Alto, Calif., 2017.}

[One sediment sample and one clam tissue sample were split and analyzed for Se and $\mathrm{Hg}$; the split results are shown here. \%, percent, $\mathrm{mg} / \mathrm{kg}$, milligrams per kilogram dry weight; SD, standard deviation; $\mathrm{CV}$, coefficient of variation]

\begin{tabular}{|c|c|c|c|c|c|c|}
\hline Sample type & Constituent & Sample & $\begin{array}{c}\text { Measured } \\
(\mathrm{mg} / \mathrm{kg})\end{array}$ & Mean & SD & CV (\%) \\
\hline \multirow{4}{*}{ Sediment } & \multirow{2}{*}{$\mathrm{Hg}$} & 20170412 SeM PAMF SD & 0.29 & \multirow[t]{2}{*}{0.30} & \multirow[t]{2}{*}{0.007} & \multirow[t]{2}{*}{2.34} \\
\hline & & 20170412 SeM PAMF SD LDUP & 0.31 & & & \\
\hline & \multirow[t]{2}{*}{$\mathrm{Se}$} & 20170612 SeM PAMF & 0.42 & \multirow[t]{2}{*}{0.42} & \multirow[t]{2}{*}{0.007} & \multirow[t]{2}{*}{1.63} \\
\hline & & 20170612 SeM PAMF Dup & 0.43 & & & \\
\hline \multirow[t]{8}{*}{ Tissue } & \multirow[t]{4}{*}{$\mathrm{Hg}$} & 20170216 SeM PAMF MPE 2 & 0.56 & \multirow[t]{2}{*}{0.57} & \multirow[t]{2}{*}{0.005} & \multirow[t]{2}{*}{0.80} \\
\hline & & 20170216 SeM PAMF MPE 2 LDUP & 0.57 & & & \\
\hline & & 20170906 SeM PAMF MPE 3 & 0.82 & \multirow[t]{2}{*}{0.83} & \multirow[t]{2}{*}{0.006} & \multirow[t]{2}{*}{0.71} \\
\hline & & 20170906 SeM PAMF MPE 3 LDUP & 0.83 & & & \\
\hline & \multirow[t]{4}{*}{$\mathrm{Se}$} & 20170216 SeM PAMF MPE 2 & 3.92 & \multirow[t]{2}{*}{3.92} & \multirow[t]{2}{*}{0.005} & \multirow[t]{2}{*}{0.12} \\
\hline & & 20170216 SeM PAMF MPE Dup & 3.93 & & & \\
\hline & & 20170906 SeM PAMF MPE & 3.08 & \multirow[t]{2}{*}{3.03} & \multirow[t]{2}{*}{0.049} & \multirow[t]{2}{*}{1.62} \\
\hline & & 20170906 SeM PAMF MPE 2 Dup & 2.98 & & & \\
\hline
\end{tabular}




\section{Appendix 4. The percent recovery ( \pm 1 standard deviation) of mercury $(\mathrm{Hg})$ and selenium $(\mathrm{Se})$ in standard reference materials.}

[N, sample size; $\mathrm{mg} / \mathrm{kg}$, milligrams per kilogram; SD, standard deviation]

\begin{tabular}{ccccccc}
$\begin{array}{c}\text { Reference } \\
\text { material }\end{array}$ & Constituent & $\mathbf{N}$ & $\begin{array}{c}\text { Certified } \\
\text { value } \\
(\mathbf{m g} / \mathbf{k g})\end{array}$ & $\begin{array}{c}\text { Recovery mean } \\
\text { SD }(\%)\end{array}$ \\
\hline TORT3 & $\mathrm{Hg}$ & 3 & 0.292 & 85 & \pm & 3 \\
NIST2976 & $\mathrm{Hg}$ & 3 & 0.061 & 97 & \pm & 1 \\
& $\mathrm{Se}$ & 3 & 1.8 & 104 & \pm & 2 \\
PACS3 & $\mathrm{Hg}$ & 2 & 3.04 & 91 & \pm & 0.1 \\
DOLT3 & $\mathrm{Se}$ & 3 & 7.1 & 100 & \pm & 1 \\
MESS & $\mathrm{Se}$ & 3 & 0.72 & 113 & \pm & 3 \\
\hline
\end{tabular}

\section{Appendix 5. Method detection limits (MDL) and reporting levels (MRL) for Inductively Coupled Plasma Optical Emission Spectrophotometry (ICP-OES) methods.}

[Concentration is reported as milligrams per liter $(\mathrm{mg} / \mathrm{L})]$

\begin{tabular}{clccccccc}
\hline Method & & Ag & Al & $\mathbf{C r}$ & $\mathbf{C u}$ & $\mathbf{F e}$ & $\mathbf{N i}$ & $\mathbf{Z n}$ \\
\hline Sediment & MDL & 0.0005 & 0.0196 & 0.0320 & 0.0174 & 0.0162 & 0.0004 & 0.0029 \\
& MRL & 0.0010 & 0.0392 & 0.0640 & 0.0347 & 0.0324 & 0.0008 & 0.0058 \\
Tissue & MDL & 0.0005 & & 0.0035 & 0.0030 & & 0.0005 & 0.0008 \\
& MRL & 0.0010 & & 0.0071 & 0.0060 & & 0.0011 & 0.0015 \\
\hline
\end{tabular}


Appendix 6. Correlation matrix of percent of fine-grained particles $(<100$ micrometers $[\mu \mathrm{m}])$ and chemical properties of surficial sediment based on monthly means of all samples collected at Palo Alto, Calif., during the period 1994-2017 (except total organic carbon [TOC] 1994-2016).

[Monthly data represent the general seasonal pattern. Data were standardized for the analysis. Correlation coefficients in bold type are significant ( $<0.05$ ).

Original mass concentration was reported in milligrams per kilogram (mg/kg), except $\mathrm{Al}, \mathrm{Fe}$, and TOC, which were reported in percent (\%). Partially extractable $\mathrm{Ag}, \mathrm{Cu}$, and $\mathrm{Zn}$ are indicated by the subscript p-extract. Data for TOC cover the period 1994-2016]

\begin{tabular}{|c|c|c|c|c|c|c|c|c|c|c|c|c|c|}
\hline Variable & $\begin{array}{c}\%<100 \\
\mu \mathrm{m}\end{array}$ & $A g_{p-e x t r a c t}$ & Al $\%$ & $\mathrm{Cr}$ & $\mathrm{Cu}_{\mathrm{p} \text {-extract }}$ & $\mathrm{Cu}$ & $\mathrm{Fe}(\%)$ & $\mathrm{Hg}$ & $\mathrm{Ni}$ & Se & $Z n_{\text {p-extract }}$ & $\mathrm{Zn}$ & TOC \\
\hline$\%<100$ um & 1.00 & & & & & & & & & & & & \\
\hline$A g_{p-e x t r a c t}$ & 0.93 & 1.00 & & & & & & & & & & & \\
\hline $\mathrm{Al} \%$ & 0.93 & 0.96 & 1.00 & & & & & & & & & & \\
\hline $\mathrm{Cr}$ & 0.90 & 0.94 & 0.99 & 1.00 & & & & & & & & & \\
\hline $\mathrm{Cu}_{\text {p-extract }}$ & 0.91 & 0.95 & 0.95 & 0.93 & 1.00 & & & & & & & & \\
\hline $\mathrm{Cu}$ & 0.92 & 0.96 & 0.98 & 0.97 & 0.99 & 1.00 & & & & & & & \\
\hline $\mathrm{Fe} \%$ & 0.87 & 0.96 & 0.95 & 0.96 & 0.96 & 0.97 & 1.00 & & & & & & \\
\hline $\mathrm{Hg}$ & 0.39 & 0.56 & 0.41 & 0.43 & 0.48 & 0.48 & 0.61 & 1.00 & & & & & \\
\hline $\mathrm{Ni}$ & 0.91 & 0.96 & 0.98 & 0.98 & 0.94 & 0.97 & 0.99 & 0.56 & 1.00 & & & & \\
\hline $\mathrm{Se}$ & 0.90 & 0.96 & 0.94 & 0.93 & 0.98 & 0.98 & 0.96 & 0.56 & 0.95 & 1.00 & & & \\
\hline $\mathrm{Zn}_{\text {p-extract }}$ & 0.94 & 0.95 & 0.95 & 0.93 & 0.99 & 0.99 & 0.95 & 0.50 & 0.95 & 0.97 & 1.00 & & \\
\hline $\mathrm{Zn}$ & 0.87 & 0.92 & 0.95 & 0.95 & 0.95 & 0.97 & 0.96 & 0.54 & 0.97 & 0.96 & 0.96 & 1.00 & \\
\hline TOC & 0.91 & 0.92 & 0.95 & 0.95 & 0.99 & 0.98 & 0.94 & 0.39 & 0.93 & 0.97 & 0.97 & 0.94 & 1.00 \\
\hline
\end{tabular}




\section{Appendix 7. Statistical summary of silver (Ag) and copper (Cu) concentrations in sediment and the clam Macoma petalum, Palo Alto, Calif., for 2017 and 1977-2017.}

[Mean, median, minimum, and maximum are calculated from all data from 1977-2017. The 2017 column presents data for the calendar year. Values for the 2017 column are annual (grand) means and the standard errors of those means. The other columns are statistics from the grand means of 1977-2017. Samples were collected between January and December of each year. Units are milligrams per kilogram dry weight of soft tissue for the clam (Macoma petalum) and milligram per kilogram dry weight for sediment.

\begin{tabular}{cccccccccc}
\hline Sample type & Element & Method & & $\mathbf{2 0 1 7}$ & & Mean & Median & Min & Max \\
\hline Sediment & $\mathrm{Ag}$ & partial extraction & 0.21 & \pm & 0.01 & 0.49 & 0.35 & 0.20 & 1.6 \\
& $\mathrm{Cu}$ & partial extraction & 14 & \pm & 1 & 22 & 19 & 12 & 55 \\
& $\mathrm{Cu}$ & near total & 30 & \pm & 1 & 44 & 43 & 30 & 86 \\
M. petalum & $\mathrm{Ag}$ & tissue digest & 4.4 & \pm & 0.3 & 23 & 4 & 2 & 106 \\
& $\mathrm{Cu}$ & tissue digest & 105 & \pm & 8 & 76 & 43 & 24 & 287 \\
\hline
\end{tabular}

\section{Appendix 8. Reproduction data for Macoma petalum, Palo Alto, Calif., 2013-2017.}

[Data signify the percentage of clams in each stage of reproduction. Reproductive, the percentage of clams in active, ripe, and spawning stages. Non-Reproductive, the percentage of clams in inactive and spent stages. Spent means the clams have released all their gametes. $\mathrm{N}$, number of clams that were analyzed; nd, no data]

\begin{tabular}{cccccccccc}
\hline Date & Inactive & Active & Ripe & Spawning & Spent & N & Reproductive & Non-Reproductive \\
\hline 16-Jan-13 & 0.0 & 30.0 & 70.0 & 0.0 & 0.0 & 10 & 100.0 & 0.0 \\
13-Feb-13 & 0.0 & 0.0 & 100.0 & 0.0 & 0.0 & 10 & 100.0 & 0.0 \\
16-Mar-13 & 0.0 & 0.0 & 100.0 & 0.0 & 0.0 & 10 & 100.0 & 0.0 \\
16-Apr-13 & 0.0 & 0.0 & 10.0 & 90.0 & 0.0 & 10 & 100.0 & 0.0 \\
14-May-13 & 60.0 & 0.0 & 0.0 & 0.0 & 40.0 & 10 & 0.0 & -100.0 \\
12-Jun-13 & 30.0 & 0.0 & 0.0 & 0.0 & 70.0 & 10 & 0.0 & -100.0 \\
1-Jul-13 & nd & nd & nd & nd & nd & nd & nd & nd \\
1-Aug-13 & nd & nd & nd & nd & nd & nd & nd & nd \\
13-Sep-13 & 50.0 & 50.0 & 0.0 & 0.0 & 0.0 & 10 & 50.0 & -50.0 \\
22-Oct-13 & 10.0 & 80.0 & 10.0 & 0.0 & 0.0 & 10 & 90.0 & nd & nd \\
1-Nov-13 & nd & nd & nd & nd & nd & nd & 10.0 \\
10-Dec-13 & 0.0 & 10.0 & 90.0 & 0.0 & 0.0 & 10 & 100.0 & 0.0 \\
\hline 8-Jan-14 & 0.0 & 30.0 & 70.0 & 0.0 & 0.0 & 10 & 100.0 & 0.0 \\
4-Feb-14 & 0.0 & 0.0 & 100.0 & 0.0 & 0.0 & 10 & 100.0 & 0.0 \\
4-Mar-14 & 0.0 & 0.0 & 90.0 & 10.0 & 0.0 & 10 & 100.0 & 0.0 \\
2-Apr-14 & 0.0 & 0.0 & 10.0 & 90.0 & 0.0 & 10 & 100.0 & 0.0 \\
6-May-14 & 10.0 & 0.0 & 10.0 & 80.0 & 0.0 & 10 & 90.0 & -10.0 \\
17-Jun-14 & 30.0 & 0.0 & 0.0 & 0.0 & 70.0 & 10 & 0.0 & -100.0
\end{tabular}




\begin{tabular}{|c|c|c|c|c|c|c|c|c|}
\hline Date & Inactive & Active & Ripe & Spawning & Spent & $\mathbf{N}$ & Reproductive & Non-Reproductive \\
\hline 1-Jul-14 & nd & nd & nd & $\mathrm{nd}$ & nd & nd & nd & nd \\
\hline 1-Aug-14 & nd & nd & nd & nd & nd & nd & nd & nd \\
\hline 9-Sep-14 & 10.0 & 90.0 & 0.0 & 0.0 & 0.0 & 10 & 90.0 & -10.0 \\
\hline 17-Oct-14 & 60.0 & 40.0 & 0.0 & 0.0 & 0.0 & 10 & 40.0 & -60.0 \\
\hline 1-Nov-14 & nd & nd & nd & nd & nd & nd & nd & nd \\
\hline 2-Dec-14 & 0.0 & 70.0 & 30.0 & 0.0 & 0.0 & 10 & 100.0 & 0.0 \\
\hline 28-Jan-15 & 0.0 & 0.0 & 90.0 & 10.0 & 0.0 & 10 & 100.0 & 0 \\
\hline $26-F e b-15$ & 0.0 & 0.0 & 40.0 & 60.0 & 0.0 & 10 & 100.0 & 0 \\
\hline 23-Mar-15 & 0.0 & 0.0 & 40.0 & 60.0 & 0.0 & 10 & 100.0 & 0 \\
\hline 8-Apr-15 & 0.0 & 0.0 & 10.0 & 10.0 & 80.0 & 10 & 20.0 & -80 \\
\hline 6-May-15 & 0.0 & 0.0 & 0.0 & 50.0 & 50.0 & 10 & 50.0 & -50 \\
\hline 8-Jun-15 & 0.0 & 0.0 & 0.0 & 0.0 & 100.0 & 10 & 0.0 & -100 \\
\hline 1-Jul-15 & nd & nd & nd & nd & nd & nd & nd & nd \\
\hline 1-Aug-15 & nd & nd & nd & nd & nd & nd & nd & nd \\
\hline 29-Sep-15 & 90.0 & 10.0 & 0.0 & 0.0 & 0.0 & 10 & 10.0 & -90 \\
\hline 28 -Oct-15 & 10.0 & 70.0 & 20.0 & 0.0 & 0.0 & 10 & 90.0 & -10 \\
\hline 1-Nov-15 & nd & nd & nd & nd & nd & nd & nd & nd \\
\hline 21-Dec-15 & 0.0 & 0.0 & 100.0 & 0.0 & 0.0 & 10 & 100.0 & 0 \\
\hline 19-Jan-16 & 0.0 & 0.0 & 100.0 & 0.0 & 0.0 & 10 & 100 & 0 \\
\hline $16-F e b-16$ & 0.0 & 0.0 & 60.0 & 40.0 & 0.0 & 10 & 100 & 0 \\
\hline 30-Mar-16 & 10.0 & 0.0 & 20.0 & 40.0 & 30.0 & 10 & 60 & -40 \\
\hline 27-Apr-16 & 0.0 & 0.0 & 40.0 & 50.0 & 10.0 & 10 & 90 & -10 \\
\hline 31-May-16 & 0.0 & 0.0 & 0.0 & 20.0 & 80.0 & 10 & 20 & -80 \\
\hline 21-Jun-16 & 0.0 & 0.0 & 0.0 & 10.0 & 90.0 & 10 & 10 & -90 \\
\hline 1-Jul-16 & nd & nd & nd & nd & nd & nd & nd & \\
\hline 1-Aug-16 & nd & nd & nd & nd & nd & nd & nd & \\
\hline 19-Sep-16 & 0.0 & 60.0 & 40.0 & 0.0 & 0.0 & 10 & 100 & 0 \\
\hline 17-Oct-16 & 0.0 & 70.0 & 30.0 & 0.0 & 0.0 & 10 & 100 & 0 \\
\hline 1-Nov-16 & nd & nd & nd & nd & nd & nd & nd & \\
\hline 19-Dec-16 & 0.0 & 10.0 & 90.0 & 0.0 & 0.0 & 10 & 100 & 0 \\
\hline 20-Jan-17 & 0.0 & 0.0 & 70.0 & 30.0 & 0.0 & 10 & 100.0 & 0 \\
\hline $16-$ Feb-17 & 0.0 & 0.0 & 100.0 & 0.0 & 0.0 & 10 & 100.0 & 0 \\
\hline 14-Mar-17 & 0.0 & 0.0 & 100.0 & 0.0 & 0.0 & 10 & 100.0 & 0 \\
\hline 12-Apr-17 & 0.0 & 0.0 & 20.0 & 80.0 & 0.0 & 10 & 100.0 & 0 \\
\hline 10-Мay-17 & 0.0 & 0.0 & 0.0 & 40.0 & 60.0 & 10 & 40.0 & -60 \\
\hline 12-Jun-17 & 30.0 & 30.0 & 0.0 & 0.0 & 40.0 & 10 & 30.0 & -70 \\
\hline 1-Jul-17 & nd & nd & nd & nd & nd & nd & nd & nd \\
\hline 1-Aug-17 & nd & nd & nd & nd & nd & nd & nd & nd \\
\hline 6-Sep-17 & 40.0 & 60.0 & 0.0 & 0.0 & 0.0 & 10 & 60.0 & -40 \\
\hline 18-Oct-17 & 0.0 & 30.0 & 60.0 & 10.0 & 0.0 & 10 & 100.0 & 0 \\
\hline 1-Nov-17 & nd & nd & nd & nd & nd & nd & nd & nd \\
\hline 11-Dec-17 & 0.0 & 33.3 & 55.6 & 11.1 & 0.0 & 9 & 100.0 & 0 \\
\hline
\end{tabular}




\section{Appendix 9. Complete list of benthic species found at Palo Alto in the year 2017.}

[Three samples are taken at each sampling event. The mean $(\sigma)$ and standard deviation (SD) of the three samples are shown]

\begin{tabular}{|c|c|c|c|c|c|c|c|c|c|c|c|c|c|c|c|c|c|c|c|c|}
\hline \multirow[t]{2}{*}{ Taxon } & \multicolumn{2}{|c|}{ 1/9/2017 } & \multicolumn{2}{|c|}{ 2/7/2017 } & \multicolumn{2}{|c|}{$3 / 6 / 2017$} & \multicolumn{2}{|c|}{ 4/12/2017 } & \multicolumn{2}{|c|}{$5 / 11 / 2017$} & \multicolumn{2}{|c|}{ 6/9/2017 } & \multicolumn{2}{|c|}{$7 / 11 / 2017$} & \multicolumn{2}{|c|}{$8 / 24 / 2017$} & \multicolumn{2}{|c|}{ 9/7/2017 } & \multicolumn{2}{|c|}{$10 / 5 / 2017$} \\
\hline & $\sigma$ & SD & $\sigma$ & SD & $\sigma$ & SD & $\sigma$ & SD & $\sigma$ & SD & $\sigma$ & SD & $\sigma$ & SD & $\sigma$ & SD & $\sigma$ & SD & $\sigma$ & SD \\
\hline \multicolumn{21}{|c|}{$\begin{array}{l}\text { PHYLUM CNIDARIA } \\
\text { Class Anthozoa } \\
\text { Order Actiniaria }\end{array}$} \\
\hline Actiniaria spp. & 1.7 & 1.5 & 0.7 & 0.6 & 0.0 & 0.0 & 0.0 & 0.0 & 0.0 & 0.0 & 0.0 & 0.0 & 0.0 & 0.0 & 0.0 & 0.0 & 0.0 & 0.0 & 0.0 & 0.0 \\
\hline \multicolumn{21}{|c|}{ Class Hydrozoa } \\
\hline Hydrozoa spp. & 0.0 & 0.0 & 0.0 & 0.0 & 0.0 & 0.0 & 0.0 & 0.0 & 0.0 & 0.0 & 0.0 & 0.0 & 0.0 & 0.0 & 0.0 & 0.0 & 0.0 & 0.0 & 0.0 & 0.0 \\
\hline \multicolumn{21}{|c|}{$\begin{array}{c}\text { PHYLUM PLATYHELMINTHES } \\
\text { Class Turbellaria }\end{array}$} \\
\hline Turbellaria spp. & 0.0 & 0.0 & 0.0 & 0.0 & 0.0 & 0.0 & 0.0 & 0.0 & 0.0 & 0.0 & 0.0 & 0.0 & 0.0 & 0.0 & 0.0 & 0.0 & 0.0 & 0.0 & 0.0 & 0.0 \\
\hline \multicolumn{21}{|c|}{ PHYLUM NEMATODA } \\
\hline Nematoda spp. & 0.0 & 0.0 & 0.0 & 0.0 & 0.0 & 0.0 & 0.0 & 0.0 & 0.0 & 0.0 & 0.0 & 0.0 & 0.0 & 0.0 & 0.0 & 0.0 & 0.0 & 0.0 & 0.0 & 0.0 \\
\hline \multicolumn{21}{|c|}{$\begin{array}{l}\text { PHYLUM ANNELIDIA } \\
\text { Class Clitellata }\end{array}$} \\
\hline Naididae spp. & 0.0 & 0.0 & 0.0 & 0.0 & 0.0 & 0.0 & 0.0 & 0.0 & 0.0 & 0.0 & 0.0 & 0.0 & 0.0 & 0.0 & 0.0 & 0.0 & 0.0 & 0.0 & 0.0 & 0.0 \\
\hline Oligochaeta spp. & 37.7 & 20.7 & 136.3 & 77.2 & 56.3 & 41.1 & 153.7 & 29.4 & 54.0 & 24.9 & 54.3 & 44.1 & 4.0 & 6.9 & 93.7 & 56.4 & 23.3 & 28.9 & 15.0 & 12.5 \\
\hline \multicolumn{21}{|c|}{$\begin{array}{l}\text { Class Polychaeta } \\
\text { Order Eunicida } \\
\text { Family Dorvilleidae }\end{array}$} \\
\hline $\begin{array}{l}\text { Schistomeringos } \\
\text { longicornis }\end{array}$ & 0.0 & 0.0 & 0.0 & 0.0 & 0.0 & 0.0 & 0.0 & 0.0 & 0.0 & 0.0 & 0.0 & 0.0 & 0.0 & 0.0 & 0.0 & 0.0 & 0.0 & 0.0 & 0.0 & 0.0 \\
\hline $\begin{array}{l}\text { Schistomeringos } \\
\text { annulata }\end{array}$ & 0.0 & 0.0 & 0.0 & 0.0 & 0.0 & 0.0 & 0.0 & 0.0 & 0.0 & 0.0 & 0.0 & 0.0 & 0.0 & 0.0 & 0.0 & 0.0 & 0.0 & 0.0 & 0.0 & 0.0 \\
\hline \multicolumn{21}{|c|}{ Family Eunicidae } \\
\hline $\begin{array}{l}\text { Marphysa } \\
\text { sanguinea }\end{array}$ & 0.0 & 0.0 & 0.0 & 0.0 & 0.0 & 0.0 & 0.0 & 0.0 & 0.0 & 0.0 & 0.0 & 0.0 & 0.0 & 0.0 & 0.0 & 0.0 & 0.0 & 0.0 & 0.0 & 0.0 \\
\hline \multicolumn{21}{|c|}{ Family Lumbrineridae } \\
\hline Scoletoma luti & 0.0 & 0.0 & 0.0 & 0.0 & 0.0 & 0.0 & 0.0 & 0.0 & 0.0 & 0.0 & 0.0 & 0.0 & 0.0 & 0.0 & 0.0 & 0.0 & 0.0 & 0.0 & 0.0 & 0.0 \\
\hline \multicolumn{21}{|c|}{$\begin{array}{l}\text { Order Phyllodocida } \\
\text { Family Glyceridae } \\
\end{array}$} \\
\hline Glycera spp. & 0.0 & 0.0 & 0.0 & 0.0 & 0.0 & 0.0 & 0.0 & 0.0 & 0.0 & 0.0 & 0.0 & 0.0 & 0.0 & 0.0 & 0.0 & 0.0 & 0.0 & 0.0 & 0.0 & 0.0 \\
\hline \multicolumn{21}{|c|}{ Family Goniadidae } \\
\hline Glycinde armiger & 0.0 & 0.0 & 0.0 & 0.0 & 0.0 & 0.0 & 0.0 & 0.0 & 0.0 & 0.0 & 0.0 & 0.0 & 0.0 & 0.0 & 0.0 & 0.0 & 0.0 & 0.0 & 0.0 & 0.0 \\
\hline
\end{tabular}




\begin{tabular}{|c|c|c|c|c|c|c|c|c|c|c|c|c|c|c|c|c|c|c|c|c|}
\hline \multirow[t]{2}{*}{ Taxon } & \multicolumn{2}{|c|}{$1 / 9 / 2017$} & \multicolumn{2}{|c|}{$2 / 7 / 2017$} & \multicolumn{2}{|c|}{$3 / 6 / 2017$} & \multicolumn{2}{|c|}{$4 / 12 / 2017$} & \multicolumn{2}{|c|}{$5 / 11 / 2017$} & \multicolumn{2}{|c|}{$6 / 9 / 2017$} & \multicolumn{2}{|c|}{$7 / 11 / 2017$} & \multicolumn{2}{|c|}{$8 / 24 / 2017$} & \multicolumn{2}{|c|}{$9 / 7 / 2017$} & \multicolumn{2}{|c|}{$10 / 5 / 2017$} \\
\hline & $\sigma$ & SD & $\sigma$ & SD & $\sigma$ & SD & $\sigma$ & SD & $\sigma$ & SD & $\sigma$ & SD & $\sigma$ & SD & $\sigma$ & SD & $\sigma$ & SD & $\sigma$ & SD \\
\hline Glycinde picta & 0.0 & 0.0 & 0.0 & 0.0 & 0.0 & 0.0 & 0.0 & 0.0 & 0.0 & 0.0 & 0.0 & 0.0 & 0.0 & 0.0 & 0.0 & 0.0 & 0.0 & 0.0 & 0.0 & 0.0 \\
\hline Glycinde sp. SF1 & 0.0 & 0.0 & 0.0 & 0.0 & 0.0 & 0.0 & 0.0 & 0.0 & 0.0 & 0.0 & 0.0 & 0.0 & 0.0 & 0.0 & 0.0 & 0.0 & 0.0 & 0.0 & 0.0 & 0.0 \\
\hline Glycinde spp. & 0.0 & 0.0 & 0.0 & 0.0 & 0.0 & 0.0 & 0.0 & 0.0 & 0.0 & 0.0 & 0.0 & 0.0 & 0.0 & 0.0 & 0.0 & 0.0 & 0.0 & 0.0 & 0.0 & 0.0 \\
\hline \multicolumn{21}{|c|}{ Family Nephtyidae } \\
\hline Nephtys caecoides & 0.0 & 0.0 & 0.0 & 0.0 & 0.0 & 0.0 & 0.0 & 0.0 & 0.0 & 0.0 & 0.0 & 0.0 & 0.0 & 0.0 & 0.0 & 0.0 & 0.0 & 0.0 & 0.0 & 0.0 \\
\hline Nephtys cornuta & 0.0 & 0.0 & 0.0 & 0.0 & 0.0 & 0.0 & 0.0 & 0.0 & 0.0 & 0.0 & 0.0 & 0.0 & 0.0 & 0.0 & 0.0 & 0.0 & 0.0 & 0.0 & 0.0 & 0.0 \\
\hline \multicolumn{21}{|c|}{ Family Nereididae } \\
\hline Alitta succinea & 0.0 & 0.0 & 0.3 & 0.6 & 0.7 & 1.2 & 0.0 & 0.0 & 0.0 & 0.0 & 0.3 & 0.6 & 0.0 & 0.0 & 0.3 & 0.6 & 0.0 & 0.0 & 0.3 & 0.6 \\
\hline \multicolumn{21}{|c|}{ Family Phyllidocidae } \\
\hline Eteone californica & 0.0 & 0.0 & 0.0 & 0.0 & 0.0 & 0.0 & 0.0 & 0.0 & 0.0 & 0.0 & 0.0 & 0.0 & 0.0 & 0.0 & 0.0 & 0.0 & 0.0 & 0.0 & 0.0 & 0.0 \\
\hline Eteone lighti & 5.7 & 2.5 & 4.0 & 1.7 & 4.0 & 2.6 & 1.7 & 2.1 & 7.7 & 1.5 & 2.3 & 0.6 & 2.7 & 2.1 & 3.3 & 4.2 & 1.3 & 1.5 & 2.3 & 1.2 \\
\hline $\begin{array}{l}\text { Phyllodoce } \\
\text { williamsi }\end{array}$ & 0.0 & 0.0 & 0.0 & 0.0 & 0.0 & 0.0 & 0.0 & 0.0 & 0.0 & 0.0 & 0.0 & 0.0 & 0.0 & 0.0 & 0.0 & 0.0 & 0.0 & 0.0 & 0.0 & 0.0 \\
\hline \multicolumn{21}{|c|}{ Family Polynoidae } \\
\hline $\begin{array}{l}\text { Harmothoe } \\
\text { imbricata }\end{array}$ & 0.0 & 0.0 & 0.0 & 0.0 & 0.0 & 0.0 & 0.0 & 0.0 & 0.0 & 0.0 & 0.0 & 0.0 & 0.0 & 0.0 & 0.0 & 0.0 & 0.0 & 0.0 & 0.0 & 0.0 \\
\hline \multicolumn{21}{|c|}{ Family Syllidae } \\
\hline Exogone lourei & 0.0 & 0.0 & 0.0 & 0.0 & 0.0 & 0.0 & 0.0 & 0.0 & 0.0 & 0.0 & 0.0 & 0.0 & 0.0 & 0.0 & 0.0 & 0.0 & 0.0 & 0.0 & 0.0 & 0.0 \\
\hline $\begin{array}{l}\text { Sphaerosyllis } \\
\text { californiensis }\end{array}$ & 0.0 & 0.0 & 0.0 & 0.0 & 0.0 & 0.0 & 0.0 & 0.0 & 0.0 & 0.0 & 0.0 & 0.0 & 0.0 & 0.0 & 0.0 & 0.0 & 0.0 & 0.0 & 0.0 & 0.0 \\
\hline Syllidae spp. & 0.0 & 0.0 & 0.0 & 0.0 & 0.0 & 0.0 & 0.0 & 0.0 & 0.0 & 0.0 & 0.0 & 0.0 & 0.0 & 0.0 & 0.0 & 0.0 & 0.0 & 0.0 & 0.0 & 0.0 \\
\hline $\begin{array}{l}\text { Typosillis } \\
\text { nipponica }\end{array}$ & 0.0 & 0.0 & 0.0 & 0.0 & 0.0 & 0.0 & 0.0 & 0.0 & 0.0 & 0.0 & 0.0 & 0.0 & 0.0 & 0.0 & 0.0 & 0.0 & 0.0 & 0.0 & 0.0 & 0.0 \\
\hline \multicolumn{21}{|c|}{$\begin{array}{l}\text { Infraclass Scolecida } \\
\text { Family Capitellidae }\end{array}$} \\
\hline $\begin{array}{l}\text { Capitella capitata } \\
\text { complex }\end{array}$ & 0.0 & 0.0 & 0.0 & 0.0 & 0.0 & 0.0 & 0.0 & 0.0 & 0.0 & 0.0 & 0.0 & 0.0 & 0.0 & 0.0 & 0.0 & 0.0 & 0.0 & 0.0 & 0.0 & 0.0 \\
\hline $\begin{array}{l}\text { Heteromastus } \\
\text { filiformis }\end{array}$ & 8.3 & 1.2 & 5.0 & 1.0 & 5.7 & 3.2 & 7.7 & 1.2 & 5.0 & 2.6 & 4.0 & 3.5 & 4.0 & 2.6 & 7.3 & 5.1 & 5.0 & 5.6 & 4.3 & 1.5 \\
\hline \multicolumn{21}{|c|}{ Family Cossuridae } \\
\hline $\begin{array}{l}\text { Cossura } \\
\text { pygodactylata }\end{array}$ & 0.0 & 0.0 & 0.0 & 0.0 & 0.0 & 0.0 & 0.0 & 0.0 & 0.0 & 0.0 & 0.0 & 0.0 & 0.0 & 0.0 & 0.0 & 0.0 & 0.0 & 0.0 & 0.0 & 0.0 \\
\hline \multicolumn{21}{|c|}{ Family Maldanidae } \\
\hline Sabaco elongatus & 0.0 & 0.0 & 0.0 & 0.0 & 0.0 & 0.0 & 0.0 & 0.0 & 0.0 & 0.0 & 0.0 & 0.0 & 0.0 & 0.0 & 0.0 & 0.0 & 0.0 & 0.0 & 0.0 & 0.0 \\
\hline \multicolumn{21}{|c|}{ Family Orbiniidae } \\
\hline $\begin{array}{l}\text { Leitoscoloptlos } \\
\text { pugettensis }\end{array}$ & 0.0 & 0.0 & 0.0 & 0.0 & 0.0 & 0.0 & 0.0 & 0.0 & 0.0 & 0.0 & 0.0 & 0.0 & 0.0 & 0.0 & 0.0 & 0.0 & 0.0 & 0.0 & 0.0 & 0.0 \\
\hline Leitoscoloplos SF1 & 0.0 & 0.0 & 0.0 & 0.0 & 0.0 & 0.0 & 0.0 & 0.0 & 0.0 & 0.0 & 0.0 & 0.0 & 0.0 & 0.0 & 0.0 & 0.0 & 0.0 & 0.0 & 0.0 & 0.0 \\
\hline
\end{tabular}




\begin{tabular}{|c|c|c|c|c|c|c|c|c|c|c|c|c|c|c|c|c|c|c|c|c|}
\hline \multirow[t]{2}{*}{ Taxon } & \multicolumn{2}{|c|}{$1 / 9 / 2017$} & \multicolumn{2}{|c|}{$2 / 7 / 2017$} & \multicolumn{2}{|c|}{$3 / 6 / 2017$} & \multicolumn{2}{|c|}{$4 / 12 / 2017$} & \multicolumn{2}{|c|}{$5 / 11 / 2017$} & \multicolumn{2}{|c|}{$6 / 9 / 2017$} & \multicolumn{2}{|c|}{$7 / 11 / 2017$} & \multicolumn{2}{|c|}{$8 / 24 / 2017$} & \multicolumn{2}{|c|}{$9 / 7 / 2017$} & \multicolumn{2}{|c|}{$10 / 5 / 2017$} \\
\hline & $\sigma$ & SD & $\sigma$ & SD & $\sigma$ & SD & $\sigma$ & SD & $\sigma$ & SD & $\sigma$ & SD & $\sigma$ & SD & $\sigma$ & SD & $\sigma$ & SD & $\sigma$ & SD \\
\hline \multicolumn{21}{|c|}{$\begin{array}{l}\text { Order Sabellida } \\
\text { Family Sabellidae }\end{array}$} \\
\hline Euchone limnicola & 1.7 & 1.2 & 0.0 & 0.0 & 0.0 & 0.0 & 0.0 & 0.0 & 0.0 & 0.0 & 0.0 & 0.0 & 0.0 & 0.0 & 0.0 & 0.0 & 0.0 & 0.0 & 0.0 & 0.0 \\
\hline Laonome calida & 0.0 & 0.0 & 0.0 & 0.0 & 0.0 & 0.0 & 0.0 & 0.0 & 0.0 & 0.0 & 0.0 & 0.0 & 0.0 & 0.0 & 0.0 & 0.0 & 0.0 & 0.0 & 0.0 & 0.0 \\
\hline Laonome sp. SF1 & 0.0 & 0.0 & 0.0 & 0.0 & 0.0 & 0.0 & 0.0 & 0.0 & 0.0 & 0.0 & 0.0 & 0.0 & 0.0 & 0.0 & 0.0 & 0.0 & 0.0 & 0.0 & 0.0 & 0.0 \\
\hline \multicolumn{21}{|c|}{$\begin{array}{l}\text { Order Spionida } \\
\text { Family Spionidae }\end{array}$} \\
\hline $\begin{array}{l}\text { Boccardia } \\
\text { pugettensis }\end{array}$ & 0.0 & 0.0 & 0.0 & 0.0 & 0.0 & 0.0 & 0.0 & 0.0 & 0.0 & 0.0 & 0.0 & 0.0 & 0.0 & 0.0 & 0.0 & 0.0 & 0.0 & 0.0 & 0.0 & 0.0 \\
\hline $\begin{array}{l}\text { Boccardiella } \\
\quad \text { ligerica }\end{array}$ & 0.0 & 0.0 & 0.0 & 0.0 & 0.0 & 0.0 & 0.0 & 0.0 & 0.0 & 0.0 & 0.0 & 0.0 & 0.0 & 0.0 & 0.0 & 0.0 & 0.0 & 0.0 & 0.0 & 0.0 \\
\hline $\begin{array}{l}\text { Dipolydora } \\
\text { brachycephala }\end{array}$ & 0.0 & 0.0 & 0.0 & 0.0 & 0.0 & 0.0 & 0.0 & 0.0 & 0.0 & 0.0 & 0.0 & 0.0 & 0.0 & 0.0 & 0.0 & 0.0 & 0.0 & 0.0 & 0.0 & 0.0 \\
\hline Dipolydora socialis & 0.0 & 0.0 & 0.0 & 0.0 & 0.0 & 0.0 & 0.0 & 0.0 & 0.0 & 0.0 & 0.0 & 0.0 & 0.0 & 0.0 & 0.0 & 0.0 & 0.0 & 0.0 & 0.0 & 0.0 \\
\hline Dipolydora spp. & 0.0 & 0.0 & 0.0 & 0.0 & 0.0 & 0.0 & 0.0 & 0.0 & 0.0 & 0.0 & 0.0 & 0.0 & 0.0 & 0.0 & 0.0 & 0.0 & 0.0 & 0.0 & 0.0 & 0.0 \\
\hline $\begin{array}{l}\text { Marenzelleria } \\
\text { neglecta }\end{array}$ & 0.0 & 0.0 & 0.0 & 0.0 & 0.0 & 0.0 & 0.0 & 0.0 & 0.0 & 0.0 & 0.0 & 0.0 & 0.0 & 0.0 & 0.0 & 0.0 & 0.0 & 0.0 & 0.0 & 0.0 \\
\hline Polydora cornuta & 0.0 & 0.0 & 0.0 & 0.0 & 0.0 & 0.0 & 0.0 & 0.0 & 0.0 & 0.0 & 0.0 & 0.0 & 0.0 & 0.0 & 0.0 & 0.0 & 0.0 & 0.0 & 0.0 & 0.0 \\
\hline Polydora limicola & 0.0 & 0.0 & 0.0 & 0.0 & 0.0 & 0.0 & 0.0 & 0.0 & 0.0 & 0.0 & 0.0 & 0.0 & 0.0 & 0.0 & 0.0 & 0.0 & 0.0 & 0.0 & 0.0 & 0.0 \\
\hline Polydora spp. & 0.0 & 0.0 & 0.0 & 0.0 & 0.0 & 0.0 & 0.0 & 0.0 & 0.0 & 0.0 & 0.0 & 0.0 & 0.0 & 0.0 & 0.0 & 0.0 & 0.0 & 0.0 & 0.0 & 0.0 \\
\hline $\begin{array}{l}\text { Pseudopolydora } \\
\text { kempi }\end{array}$ & 0.0 & 0.0 & 0.0 & 0.0 & 0.0 & 0.0 & 0.0 & 0.0 & 0.0 & 0.0 & 0.0 & 0.0 & 0.0 & 0.0 & 0.0 & 0.0 & 0.0 & 0.0 & 0.0 & 0.0 \\
\hline $\begin{array}{l}\text { Pseudopolydora } \\
\text { paucibranchiata }\end{array}$ & 0.0 & 0.0 & 0.0 & 0.0 & 0.0 & 0.0 & 0.3 & 0.6 & 0.0 & 0.0 & 0.0 & 0.0 & 0.0 & 0.0 & 0.0 & 0.0 & 0.0 & 0.0 & 0.0 & 0.0 \\
\hline $\begin{array}{l}\text { Pseudopolydora } \\
\text { spp. }\end{array}$ & 0.0 & 0.0 & 0.0 & 0.0 & 0.0 & 0.0 & 0.0 & 0.0 & 0.0 & 0.0 & 0.0 & 0.0 & 0.0 & 0.0 & 0.0 & 0.0 & 0.0 & 0.0 & 0.0 & 0.0 \\
\hline Spionidae spp. & 0.0 & 0.0 & 0.0 & 0.0 & 0.0 & 0.0 & 0.0 & 0.0 & 0.0 & 0.0 & 0.0 & 0.0 & 0.0 & 0.0 & 0.0 & 0.0 & 0.0 & 0.0 & 0.0 & 0.0 \\
\hline $\begin{array}{l}\text { Streblospio } \\
\text { benedicti }\end{array}$ & 0.7 & 0.6 & 1.0 & 1.0 & 6.3 & 11.0 & 17.3 & 11.7 & 17.3 & 9.7 & 9.0 & 11.3 & 0.7 & 1.2 & 3.3 & 2.5 & 1.0 & 1.7 & 0.0 & 0.0 \\
\hline
\end{tabular}




\section{Appendix 10. Benthic species name changes as of 2017.}

\begin{tabular}{|c|c|}
\hline Current Species Name & Formerly Document As \\
\hline \multicolumn{2}{|c|}{$\begin{array}{c}\text { PHYLUM CNIDARIA } \\
\text { Class Anthozoa } \\
\text { Order Actiniaria }\end{array}$} \\
\hline Actiniaria spp. & Anthozoa, Unid. Actiniaria, Actiniaria unid. spp. \\
\hline \multicolumn{2}{|c|}{$\begin{array}{l}\text { PHYLUM PLATYHELMINTHES } \\
\text { Class Turbellaria }\end{array}$} \\
\hline Turbellaria spp. & Turbellaria, Turbellaria unid. spp. \\
\hline \multicolumn{2}{|c|}{ PHYLUM NEMATODA } \\
\hline Nematoda spp. & Nematoda unid. spp. \\
\hline \multicolumn{2}{|c|}{$\begin{array}{l}\text { PHYLUM ANNELIDA } \\
\text { Class Clitellata }\end{array}$} \\
\hline Naididae spp. & Naididae, Naididae unid. spp. \\
\hline Oligochaeta spp. & $\begin{array}{l}\text { Oligochaeta, Unid. Oligochaeta family, } \\
\text { Oligochaeta unid. spp. }\end{array}$ \\
\hline \multicolumn{2}{|c|}{ Class Polychaeta } \\
\hline Polychaeta spp. & $\begin{array}{l}\text { Unid. Polychaeta, Polychaeta, Polychaeta unid. } \\
\text { spp. }\end{array}$ \\
\hline \multicolumn{2}{|c|}{$\begin{array}{l}\text { Order Eunicida } \\
\text { Family Dorvilleidae }\end{array}$} \\
\hline Schistomeringos longicornis & Dorvillea longicornis \\
\hline Schistomeringos annulata & $\begin{array}{l}\text { Dorvillea annulata, Dorvillea longicornuta, } \\
\text { Schistomeringos longicornuta, Dorvillea rudolphi }\end{array}$ \\
\hline \multicolumn{2}{|c|}{$\begin{array}{l}\text { Order Phyllodocida } \\
\text { Family Glyceridae }\end{array}$} \\
\hline Glycera spp. & Glycera unid. spp. \\
\hline \multicolumn{2}{|c|}{ Family Goniadidae } \\
\hline Glycinde picta & Glycinde polygnatha \\
\hline Glycinde sp. SF1 & Glycinde unid. Sp. SF1 \\
\hline Glycinde spp. & Glycinde unid. Spp. \\
\hline \multicolumn{2}{|c|}{ Family Nereididae } \\
\hline Alitta succinea & Neanthes succinea \\
\hline \multicolumn{2}{|c|}{ Family Phyllidocidae } \\
\hline Eteone spp. & Eteone? Californica, Eteone unid. spp. \\
\hline \multicolumn{2}{|r|}{ Family Syllidae } \\
\hline Sphaerosyllis unid. sp. A & Sphaerosylis spp. \\
\hline \multicolumn{2}{|c|}{$\begin{array}{l}\text { Infraclass Scolecida } \\
\text { Family Capitellidae }\end{array}$} \\
\hline \multicolumn{2}{|c|}{ Family Maldanidae } \\
\hline Maldanidae spp. & Unid. Maldanidae, Maldanidae unid. spp. \\
\hline \multicolumn{2}{|c|}{$\begin{array}{l}\text { Order Sabellida } \\
\text { Family Sabellidae }\end{array}$} \\
\hline Euchone spp. & Euchone unid. spp. \\
\hline \multicolumn{2}{|c|}{$\begin{array}{l}\text { Order Spionida } \\
\text { Family Spionidae }\end{array}$} \\
\hline Polydora cornuta & Polydora lighti, Polydora ligni \\
\hline Polydora spp. & Polydora unid. Spp. \\
\hline Spionidae spp. & $\begin{array}{l}\text { Unid. Spionidae, Spionidae Unidentified, Spionidae } \\
\text { unid. Spp. }\end{array}$ \\
\hline
\end{tabular}




\begin{tabular}{lc}
\hline \multicolumn{1}{c}{ Current Species Name } & Formerly Document As \\
\hline Cirratulidae spp. & Order Terebellida \\
& Thily Cirratulidae \\
Chironomidae spp. & Tharyx spp. ?, Cirratulidae, Cirratulidae unid. Spp. \\
& Class Insecta \\
Calanoida spp. & Chironomidae, Chironomidae unid. spp. \\
Harpacticoida spp. & Class Maxillopoda \\
& Calanoida, Calanoida unid. spp. \\
Gastropod unid. sp. B & Harpacticoida, Harpacticoida unid. spp. \\
& Class Gastropoda \\
Philine spp. & Unidentified Gastropoda B \\
& Order Cephalaspidea \\
Odetta bisuturalis & Family Philinidae \\
Pyramidellidea spp. & Philine unid. spp. \\
& Order Heterostropha \\
Ilyanassa obsoleta & Family Pyramidellidae \\
\hline
\end{tabular}


ISSN 2331-1258 (online)

https://doi.org/10.3133/

ofr20181107 